University of Wyoming College of Law

Law Archive of Wyoming Scholarship

2-24-2016

\title{
The Colorado River Revisited
}

Jason Anthony Robison

University of Wyoming College of Law, jrobiso8@uwyo.edu

Follow this and additional works at: https://scholarship.law.uwyo.edu/faculty_articles

\section{Recommended Citation}

Robison, Jason Anthony, "The Colorado River Revisited" (2016). Faculty Articles. 31.

https://scholarship.law.uwyo.edu/faculty_articles/31

This Article is brought to you for free and open access by the UW College of Law Faculty Scholarship at Law Archive of Wyoming Scholarship. It has been accepted for inclusion in Faculty Articles by an authorized administrator of Law Archive of Wyoming Scholarship. 


\title{
UNIVERSITY OF COLORADO LAW REVIEW
}

Volume 88, Issue 3

\section{THE COLORADO RIVER REVISITED}

\author{
JASON ANTHONY ROBISON*
}

Fifty years ago, former Stanford Law School Dean Charles Meyers published The Colorado River, 19 STAN. L. REV. 1 (1966), arguably the most famous piece of legal scholarship ever written on this vital water source and the complex body of laws governing its flows-colloquially, the "Law of the River." That piece and a companion, The Colorado River: The Treaty with Mexico, 19 STAN. L. REV. 367 (1967), offered seminal accounts of the legal histories, doctrinal features, and unresolved perplexities of the Law of the River's international and interstate allocation framework. Five decades later, between thirty-five and forty million U.S. residents rely on flows controlled by this framework, and a historic drought and unprecedented water supply and demand imbalance face the Colorado River Basin. It is a transformative time for the Law of the River, and this Article

\footnotetext{
* Associate Professor, University of Wyoming College of Law. S.J.D., Harvard Law School (2013); LL.M., Harvard Law School (2009); J.D., University of Oregon School of Law (2006); B.S., Environmental Studies, University of Utah (2003). This Article is dedicated to A. Dan Tarlock. While a student at Stanford Law School, Professor Tarlock served as Charles Meyers's research assistant in the preparation of The Colorado River, authoring Part III on the Upper Basin as well as portions of the Introduction. A lifelong friendship blossomed. I am deeply indebted to Professor Tarlock for the time and knowledge he kindly contributed to this piece. Several other colleagues also generously offered feedback, including Brian Annes, Holly Doremus, Terry Fulp, Itzchak Kornfeld, Owen Lammers, Larry MacDonnell, Dan McCool, John Shields, Sally Spener, Jack Tuholske, John Weisheit, and Steve Wolff. Many thanks to all. I am grateful to Vermont Law School for the opportunity to submit a draft at the Sixth Annual Colloquium on Environmental Scholarship. I also greatly appreciate the diligent efforts of the editors of Colorado Law Review and my research assistant, Peter Levish, at the University of Wyoming College of Law. Funding for this Article was graciously provided from the Carl M. Williams Faculty Research Fund. Any errors or omissions are solely my own.
} 
revisits Meyers's scholarship from this vantage point. It begins by considering climate change and related dynamic changes in and around the basin over the past fifty years. It then considers the evolution of the Law of the River's allocation framework across this period-particularly, since the historic drought's onset in 2000. Finally, focusing on the concept of "adaptive framing," the Article synthesizes common patterns in the allocation framework's evolution, and offers prescriptions and prognoses regarding the continuation of these patterns in the future.

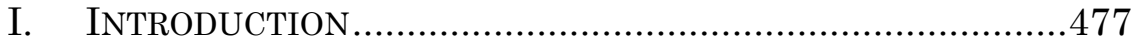

II. Change \& Continuity IN The Colorado RIVER

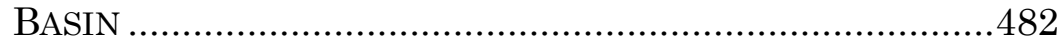

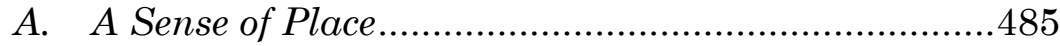

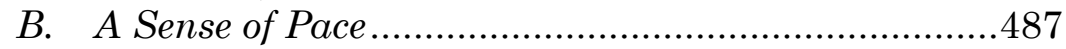

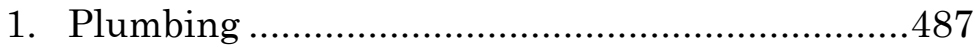

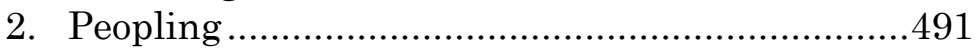

3. Point Tipping................................................495

III. EVOLUTION OF THE INTERNATIONAL \& INTERSTATE

ALLOCATION FRAMEWORK ............................................500

A. U.S.-Mexico Treaty .............................................. 501

1. International Apportionment..........................502

2. Of "Extraordinary Drought" \& Other Perplexities......................................................503

3. Minute 319: Pragmatism and Invention in Treaty Implementation ....................................505

B. Colorado River Compact .......................................509

1. Domestic Basinwide Apportionment .................510

2. Ambiguities in the Law of the River's Constitution......................................................513

3. Pragmatism Redux: Interim Guidelines \& Compact Implementation..............................5 517

C. Upper Basin Compact .........................................522

1. Upper Basin Apportionment ............................522

2. Compact Calls \& Curtailments.........................525

a. Administration: Article IV, PPRs \& Measurement Methods................................527

b. Avoidance: Drought Contingency Planning ..530

D. Arizona v. California Decree ..................................533

1. Lower Colorado River Apportionment...............534

2. Structural Deficit \& Shortages .........................556 
a. Administration: Shortage "Sharing". 542

b. Avoidance: Water Banking, ICS/DSS \& Pilot Programs.

IV. Synthesis, PROGNOSIS \& PRESCRIPTION:

ADAPTIVE FRAMING

A. Of Boundaries: Rationing \& Risk Allocation ...........552

1. Operational Apportionment Implementation.....552

2. Toward Further Clarity, Comity \& Equity........553

B. Of Surrogacy: Interpretive Conflict Management.....556

1. Surrogacy....

2. Second-Best Solutions \& Surrogacy

Reassessed

C. Of Economy: Constraint Avoidance \& Mitigation ....560

1. Programmatic Iteration ..................................560

2. Diffusion \& Performance-Based Assessment .....561

V. CONCLUSION.... .568

\section{INTRODUCTION}

For Secretary of the Interior Stewart Udall, northern Arizona was "home country," 1 his connection to it deep and familial, his affinity for it gushing and palpable. "One needs superlatives to describe this special region of the United States, this Colorado plateau country," declared the Secretary, "because both in the terms of the works of man-and we're on a great engineering feat, standing on it here today-and in the terms of the works of nature, there are superlative things here." ${ }^{2}$ The date was September 22, 1966, and the "great engineering feat" on which the Secretary stood beside other federal, state, and tribal dignitaries was Glen Canyon Dam. Perhaps most notable among his colleagues on this historic occasion was "Lady Bird" Johnson, First Lady and wife of President Lyndon B. Johnson, for it was upon her shoulders that the dam's dedication rested. "[T]here is only one sculptured earth of painted canyons," described the First Lady in her dedicatory remarks, "and that is here on the Colorado Plateau." ${ }^{3}$ Through these words and other truly eloquent

1. U.S. Bureau of Reclamation, Glen Canyon Dam Dedication CEREMONY 2-3 (1966), http://archive.library.nau.edu/cdm/ref/collection/cpa/id/ 36130 [https://perma.cc/H79B-J9VV] [hereinafter GLEN CANYON TRANSCRIPT].

2. Id.

3. Id. at 8 . 
expressions, the First Lady's dedication channeled the views of the Secretary and other attendees regarding the beauty and ancient texture of this distinct place. Yet undoubtedly so too did her appraisal of the dam. "As I look around at this incredibly beautiful and creative work," the First Lady stated in reference to the "plug in the river" seen earlier from her plane, "it occurs to me that this is a new kind of "writing on the walls'-a kind that says proudly and beautifully 'Man was here.'... I am proud to dedicate such a significant and beautiful manmade resource. I am proud that "Man is here."'4

Indeed, "Man is here," to co-opt the First Lady's sentiment five decades later. Our collective thirst for water from the river system impounded by Glen Canyon Dam has given rise in contemporary times to an unprecedented imbalance between the satiation of that thirst on one hand, and, to co-opt Secretary Udall in equal measure, the hydrological bounty of this "superlative" corner of North America on the other. It is a challenging phase for all who value the Colorado River and its tributaries as a lifeline-or, more precisely, as a giver of those things that make life both possible and worthwhile.

To convey the situation in slightly more concrete terms, no fewer than thirty-five to forty million people in the United States-roughly equivalent to between one in eight and one in nine U.S. residents-currently rely on water from the Colorado River Basin. ${ }^{5}$ For the first time in the basin's history, the water demands of this population exceeded available water supplies on average across the past decade. ${ }^{6}$ Absent changes in the status quo, the Bureau of Reclamation's extensive Colorado River Basin Water Supply and Demand Study (Basin Study) projected this supply-demand imbalance will widen over the next five decades-perhaps to the median projection of 3.2

4. Id. at 8-9.

5. U.S. BuREAU OF REClamation, Colorado River Basin StakeHolders MOVING FORWARD TO ADDRESS CHALLENGES IDENTIFIED IN THE COLORADO RIVER BASIN WATER SUPPly AND DEMAND StUdy, PHASE I REPORT 1 (2015), http://www.usbr.gov/lc/region/programs/crbstudy/MovingForward/Phase1Report/f ullreport.pdf [https://perma.cc/E5K3-V4QE] [hereinafter PHASE I REPORT]; U.S. and World Population Clock, U.S. CEnsus BUREAU, http://www.census.gov/ popclock/ (last visited Aug. 26, 2016) [https://perma.cc/T5LQ-YUVD].

6. U.S. BUREAU OF REClamation, COLORADO RIVER BASIN WATER SUPPLY AND DEMAND STUDY, STUDY REPORT SR-7 fig.2 (2012), http://www.usbr.gov/lc/ region/programs/crbstudy/finalreport/Study\%20Report/CRBS_Study_Report_FIN AL.pdf [https://perma.cc/Y4MP-HKA8] [hereinafter STUDY REPORT]. 
million acre-feet (maf), equivalent to an annual shortfall of more than one-trillion gallons of water, but perhaps more or less. ${ }^{7}$ Climate change is a key variable in this unfolding equation. Average surface air temperature in the basin has risen 2.5 degrees Fahrenheit (1.39 degrees Celsius) since around the turn of the twentieth century, and a roughly 2.0 degree Fahrenheit (1.11 degree Celsius) increase has been observed since roughly the time of Glen Canyon Dam's dedication (from 1970 to 2005). ${ }^{8}$ In a similar fashion, the basin has been in a historic drought for the past decade-and-a-half, with natural flows at the dividing point between the Upper Basin and Lower Basin, "Lee Ferry," declining between 2000 and 2015 to levels that are lower than any observed over the past century and some of the lowest over the past 1,200 years based on paleo records. ${ }^{9}$ The Basin Study projected these climatic and hydrological patterns will persist for the next half century, occurring contemporaneously with demands for Colorado River System water unlike anything seen in the basin's history. 10

In truly countless ways, these daunting yet opportune circumstances involve an elaborate body of laws called the "Law of the River," 11 with arguably the most famous piece of

7. See PHASE I REPORT, supra note 5, at 3 (describing plausible supplydemand imbalances ranging "from no imbalance to 6.8 million acre-feet (MAF) with a median of 3.2 MAF in 2060"). One acre-foot is the volume of water required to cover an acre of land to a depth of one foot-equivalent to 325,851 gallons. Water Science Glossary of Terms, U.S. GEOLOGICAL SURVEY, http://water.usgs.gov/ edu/dictionary.html (last visited Oct. 30, 2016) [https://perma.cc/5WWJ-2U62]. The Basin Study's median imbalance projection thus equates to $1,042,723,200,000$ gallons.

8. U.S. Bureau of Reclamation, Colorado River Basin Water Supply AND Demand Study, TeChNicAl REPORT B-WATER SupPly Assessment B-16 fig.B-7 (2012), http://www.usbr.gov/lc/region/programs/crbstudy/finalreport/ Technical\%20Report\%20B\%20-\%20Water\%20Supply\%20Assessment/TR-B_

Water_Supply_Assessment_FINAL.pdf [https://perma.cc/N847-JLV2] [hereinafter TECHNICAL REPORT B].

9. Drought in the Colorado River Basin, U.S. DEPARTMENT OF THE INTERIOR, https://www.doi.gov/water/owdi.cr.drought/en/ (last visited Aug. 9, 2016) [https://perma.cc/N4VV-KEE8] [hereinafter Open Data].

10. But see Letter from Victor R. Baker, Regents' Professor of Hydrology and Water Res., Univ. of Ariz., to Sally Jewell, Sec'y of the Interior 2 (Oct. 12, 2015), http://www.livingrivers.org/pdfs/LetterToJewell13October2015Final.pdf [https://perma.cc/2WVX-RHW3] [hereinafter Baker Letter] (questioning water demand forecasts).

11. This colloquial term generally refers to the collective body of federal and state laws governing allocation and management of water in the Colorado River 
legal scholarship ever penned on this corpus coming from former Stanford Law School Dean Charles Meyers. ${ }^{12}$ A native Texan like Lady Bird Johnson, Meyers published his "magisterial" article, ${ }^{13}$ The Colorado River, in November 1966 - two months after the First Lady dedicated Glen Canyon Dam-following suit the next year with a co-authored companion piece, The Colorado River: The Treaty with Mexico. ${ }^{14}$ Neither the subject matter nor the timing of these articles were a bit surprising, for Meyers had begun his work in water law "at the top" of the field a decade prior, ${ }^{15}$ serving as law clerk to Special Master Simon Rifkind from 1956 to 1960 during the epic Colorado River battle of Arizona $v$. California. ${ }^{16}$ Eleven years in the making, the Supreme Court handed down its principal decision in this original jurisdiction action in 1963. ${ }^{17}$ It announced (or arguably clarified) an apportionment for the Lower Colorado River that interfaced with apportionments previously established by the Colorado River Compact in 1922,18 the U.S.-Mexico Treaty in $1944,{ }^{19}$ and the Upper Colorado River Basin Compact in 1948. ${ }^{20}$ In this manner, Arizona $v$. California implanted the final component of the Law of the River's integrated international and

system. See generally Lawrence J. MacDonnell, Colorado River Basin, in 4 WATER AND WATER RightS 5 (Amy K. Kelley ed., 2011) (surveying Law of the River).

12. Meyers had a storied career in natural resources law. See, e.g., G. EMLEN Hall, High and Dry: The Texas-New Mexico Struggle for the Pecos River 164-96 (2002); A. Dan Tarlock, Tribute, 29 NAT. RES. J. 327, 327-29 (1989).

13. HALL, supra note 12, at 168.

14. Charles J. Meyers \& Richard L. Noble, The Colorado River: The Treaty with Mexico, 19 Stan. L. REv. 367 (1967); Charles J. Meyers, The Colorado River, 19 STAN. L. REV. 1 (1966).

15. Tarlock, supra note 12 , at 328-29.

16. 373 U.S. 546 (1963); Tarlock, supra note 12, at 328-29; HALL, supra note 12, at 168. The U.S. Supreme Court appoints Special Masters to preside over interstate water suits in the manner of trial judges, and Meyers actually passed away while serving in this capacity for a dispute between New Mexico and Texas over the Pecos River Compact. HALL, supra note 12, at 164-96. For insights into Special Master Rifkind and his work in Arizona v. California, see Meyers, supra note 14 , at 43,51 n.207.

17. 373 U.S. 546 (1963).

18. Colorado River Compact, 1923 Colo. Sess. Laws 684, Colo. Rev. StAT. § 37-61-101 to -104 (2016) [hereinafter Compact].

19. Utilization of the Waters of the Colorado and Tijuana Rivers and of the Rio Grande, Treaty Between the United States of America and Mexico, U.S.-Mex., Feb. 3, 1944, T.S. 994 [hereinafter Treaty].

20. Upper Colorado River Basin Compact, ch. 48, 63 Stat. 31 (1949) [hereinafter Upper Basin Compact]. 
interstate allocation framework for the Colorado River System. Meyers's scholarship emerged at this historic confluence, channeling the wealth of knowledge he had gained while working alongside Special Master Rifkind to offer seminal accounts of the legal histories, doctrinal nuances, and thenlooming legal and policy issues associated with the nested apportionments. $^{21}$

Taking Meyers's publication of The Colorado River in 1966 as its starting point, this Article considers, from both positive and normative angles, the Law of the River's retrospective evolution over the past fifty years through historical periods dubbed the "Big Buildup" and "Era of Limits," and its prospective evolution forging ahead into the latter period. ${ }^{22}$ There are numerous facets to this evolution, including salient developments related to water rights held by American Indian tribes within the Colorado River Basin, ${ }^{23}$ as well as recovery and conservation programs being implemented for endemic fish species listed under the Endangered Species Act. ${ }^{24}$ For sake of narrowing, however, my discrete focus is on the core matters around which Meyers's scholarship itself revolved: the four apportionments identified above that constitute the Law of the River's international and interstate allocation framework.

The Article flows in three Parts to this end. Part II initially grounds the inquiry in place. It puts the evolution of the Law of the River's allocation framework into spatial and temporal

21. HALL, supra note 12, at 168 (describing how The Colorado River "summed up what Meyers had seen and learned in the California-Arizona battle"). More precisely, as elaborated in Part III, The Colorado River addressed the historical, doctrinal, and policy matters noted for the Colorado River Compact, Upper Colorado River Basin Compact, and Arizona v. California decree, while The Colorado River: The Treaty with Mexico covered similar ground in relation to that instrument.

22. Charles Wilkinson, Fire on the Plateau: Conflict and Endurance IN THE AMERICAN SouTHWEST xii (1999) ("Big Buildup"); Felix L. Sparks, Article Update, Synopsis of Major Documents and Events Relating to the Colorado River, 3 U. DENV. WATER L. REV. 339, 341-42 (2000) ("Era of Limits").

23. See generally Amy Cordalis \& Daniel Cordalis, Indian Water Rights: How Arizona v. California Left an Unwanted Cloud over the Colorado River Basin, 5 ARIZ. J. ENVTL. L. \& POL'Y 333 (2015) (discussing Arizona v. California's historical and contemporary implications for tribal water rights in Colorado River Basin).

24. For an excellent source addressing the history and features of these programs, the value choices underlying them, and ultimately the future of our socio-ecological systems in and around the Colorado River Basin, see ROBERT W. Adler, Restoring Colorado River Ecosystems: A Troubled Sense of IMMENSITY (2007). 
context by introducing the Colorado River Basin as an actual place simultaneously shaped by and shaping this body of laws. Proceeding on this basis, the discussion then illuminates dynamic changes in and around this place since Meyers's scholarship, including the ongoing water supply and demand imbalance. Part III, in turn, tracks the allocation framework's evolution to date, particularly over the past two decades during the historic drought. It introduces the framework's constituent apportionments, singularly and relationally, and chronicles key milestones associated with their evolution since the drought's onset and slightly before. Finally, Part IV synthesizes the preceding content and sets eyes on the future. Through the concept of "adaptive framing," it identifies and discusses common adaptive patterns apparent when stepping back and analyzing the apportionments' evolutionary paths detailed in Part III from a comparative perspective. The specific nature of these patterns, and the various developments encompassed within them, are addressed fully in Parts IV and III, respectively. Painting in broad strokes, the patterns generally concern three topics: (1) water-use rationing and risk allocation, (2) management of interpretive conflicts surrounding framing provisions of the apportionments, and (3) avoidance or mitigation of constraints on water use imposed by these instruments. Part IV brings these patterns to light and assesses their persistence, including offering prognoses and prescriptions regarding how the allocation framework foreseeably will, and arguably should, evolve in coming years. Underpinning this entire inquiry is the viewpoint that the Law of the River is in the midst of a truly transformative stage, and that citizens and policymakers alike bear an intergenerational obligation to steward this complex body of laws in its further evolution through this era. As goes the Law of the River, so go the fates of all it touches. For a glimpse of this rich, indelible patrimony, we turn to the Colorado River Basin itself.

\section{Change \& Continuity In THE COLORADo RIVER BASIN}

" $[\mathrm{H}]$ ere you have in this one region oil, gas, uranium, great reserves of coal, and, of course, the other indispensable resource ... water.... Water is the key resource, and you can develop your other resources if you husband your water and 
use it wisely." 25 Secretary Udall offered this perspective on the Colorado River Basin's natural resources the year after his appointment by President John F. Kennedy. ${ }^{26}$ The setting was Navajo Dam's dedication on September 15, 1962-an event plainly significant for the project itself, but for present purposes even more so for the infrastructural wave of which the project was the vanguard. It was the Colorado River Storage Project Act that had put this wave into motion in 1956. ${ }^{27}$ Navajo Dam was the "firstborn" of four large-scale dam and reservoir projects authorized by the Act. It would be followed by the Colorado River Basin Project Act ${ }^{28}$ in 1968, with Meyers's scholarship emerging in the interim. Taken together, the plumbing system spawned by these laws would fundamentally change the make-up of the basin and vast outlying areas.

Charles Wilkinson coined the term the "Big Buildup" to capture the multifarious aspects of this era at the millennium's turn. ${ }^{29}$ They have involved all of the resources mentioned by Secretary Udall, and the Colorado River has been central among them. For the most part, the Big Buildup now appears to have run its course, and a transition seems to have been made to an era of intertwined hydrological and institutional limits (Era of Limits). ${ }^{30}$ Illustrative of this view are the facts that no major water projects have been authorized in the basin since the late 1960s and that existing and projected demands for Colorado River System water in many cases pose serious viability and sustainability questions given water supply limits. From another perspective, however, the Big Buildup appears to have been in full swing for the past fifty years and apparently is poised to continue, in some peoples' minds, for several decades. This perception is particularly evident with respect to population growth and water demand projections. After conveying a sense of the basin as a place, this Part sheds

25. U.S. Bureau of Reclamation, Navajo Dam Dedication 15 (1962), http://archive.library.nau.edu/cdm/ref/collection/cpa/id/36168 [https://perma.cc/ EJH7-8L3J] [hereinafter NAVAJO TRANSCRIPT].

26. Past Secretaries, U.S. DEP'T OF THE INTERIOR, http://www.doi.gov/whoweare/past_secretaries.cfm (last visited Aug. 26, 2016) [https://perma.cc/2GU3-27TF].

27. Colorado River Storage Project Act, 43 U.S.C. $\S \S 620-620$ o (2012).

28. Colorado River Basin Project Act, 43 U.S.C. $\S \S 1501-1556$ (2012).

29. WILKINSON, supra note 22 , at xii.

30. Sparks, supra note 22, at 341-42. 
light on these patterns and the dizzying pace of change in and around the basin across the conjoined periods.

Figure 1. Colorado River Basin and Export Areas ${ }^{31}$

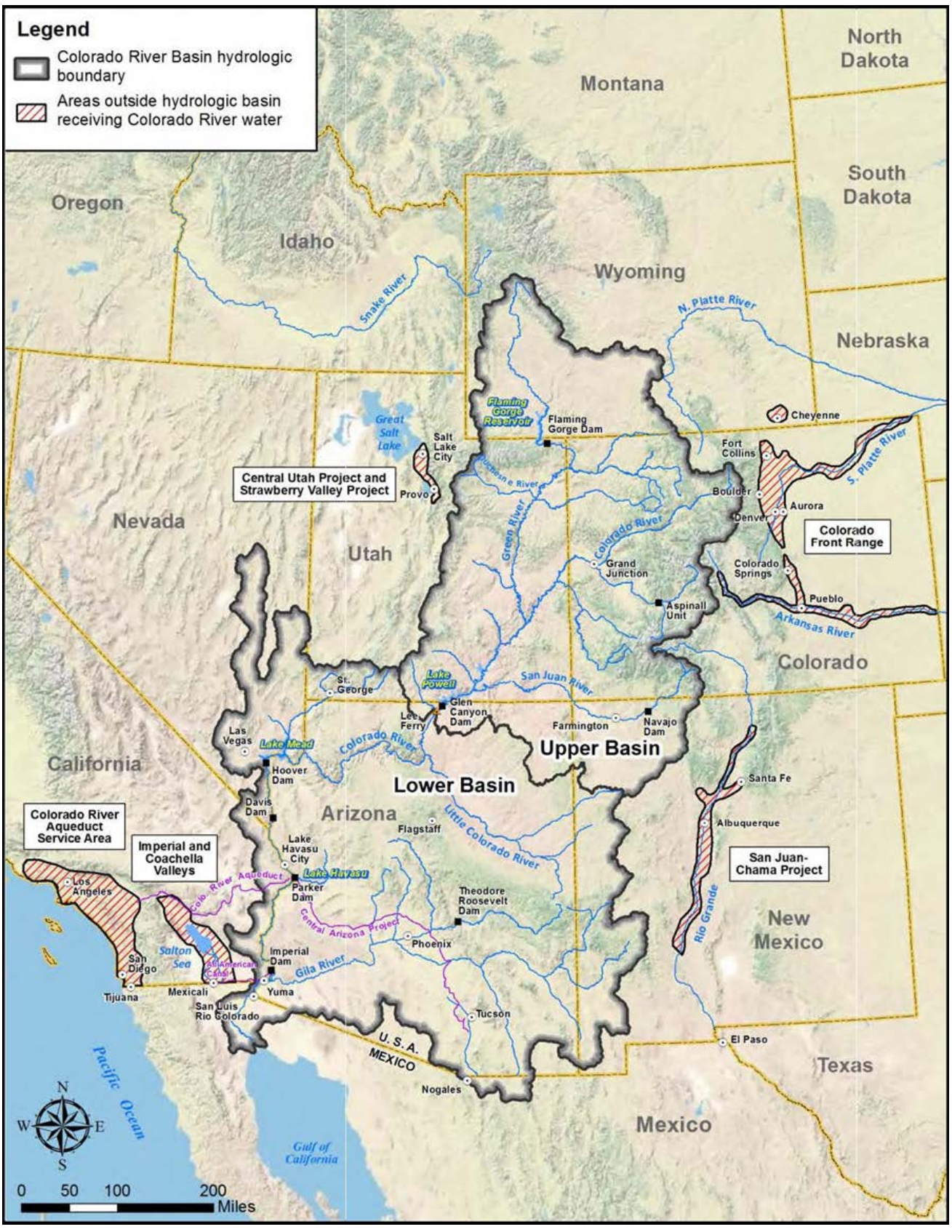

31. PhASE I REPORT, supra note 5, at 1-3 fig.1-1. 


\section{A. A Sense of Place}

Jagged, alpine mountains-forested green, snowcapped white, yet in the main rugged and earthen true to their essence as the Rocky Mountains-converge in the Colorado River Basin with a visceral, sunbaked landscape of low desert and its countless red, orange, and chocolate hues. Proverbial seas of sagebrush span the high desert between these topographical extremes, receding as far as the eye can see away from ranges like Wyoming's Winds, Colorado's San Juans, and Utah's Uintas and Wasatch, later to blend seamlessly into otherworldly red rock country. It is generally an arid and semiarid place. The Upper Basin mountains bear snow and rain at variable and sometimes abundant levels, but these gifts fall in counterpoise to the basin's expansive, dry interior and often scorching Lower Basin reaches. ${ }^{32}$ The basin is vast-occupying 244,000 square miles in the southwestern United States and northwestern Mexico 33 _and immeasurably rich in both material and immaterial resources.

Multi-layered legal and political lines adhere to the Colorado River Basin in modern times. It encompasses portions of seven U.S. states (Arizona, California, Colorado, Nevada, New Mexico, Utah, and Wyoming)—collectively, the "Basin States"-and two Mexican states (Baja California and Sonora). ${ }^{34}$ Twenty-eight American Indian reservations likewise fall within the basin, including the two largest in the United States: the Navajo Nation in the Four Corners region and the Uintah and Ouray Reservation in eastern Utah. ${ }^{35}$ Also pervasive are diverse lands owned and managed by the federal government, including hallmarks like Rocky Mountain National Park at the Colorado River's headwaters, and Grand Canyon National Park near the dividing point of the Upper

32. For a map depicting the basin's climate, see TECHNICAL REPORT B, supra note 8 , at B-14 fig.B-5.

33. See MacDonnell, supra note 11, at 6 .

34. PHASE I REPORT, supra note 5, at 1-3 fig.1-1.

35. For a reservations map, see U.S. BuREAU of REClamation, Colorado River BAsin WATER SupPly AND DEMAND STUdy, TECHNiCAL REPORT C - WATER DEMAND ASSESSMENT C-40 fig.C-17 (2012), http://www.usbr.gov/lc/region/ programs/crbstudy/finalreport/Technical\%20Report\%20C\%20\%20Water\%20Dema nd\%20Assessment/TR-C-Water_Demand_Assessmemt_FINAL.pdf [https://perma.cc/84GZ-UPEU] [hereinafter TECHNICAL REPORT C]. 
Basin and Lower Basin at Lee Ferry. ${ }^{36}$

As for the river system itself, a journey of more than 1,400 miles marks the Colorado River's meandering course from its headwaters in the Colorado Rockies to its delta at the Gulf of California, ${ }^{37}$ though it has been rare for significant flows to reach the river's mouth for over a half century. ${ }^{38}$ The primary tributary of the Colorado River is the Green River. ${ }^{39}$ Its headwaters lie in southwestern Wyoming's Wind River Range, and it is along this historic water body that visionary John Wesley Powell commenced the first scientific expedition of the Colorado River System in 1869.40 The San Juan River, too, contributes generously to the Colorado River's mainstream, flowing from its alpine headwaters in southwestern Colorado as the system's third largest tributary. ${ }^{41}$ Of greatest hydrological significance within the Lower Basin is the Gila River. It stems from eastern New Mexico's Black Rangemerging with the Salt and Verde Rivers in central Arizonaand, if its flows are not fully consumed after traversing the entire Grand Canyon State, it joins the Colorado River at Yuma.

Varied and voluminous uses are made of Colorado River System water. This subject is treated fully below, but it is worth reiterating that thirty-five to forty million people in the United States utilize these flows-again, equivalent to between one in eight and one in nine U.S. residents. ${ }^{42}$ Major

36. For a federal lands map, see NAT'L Atlas, U.S. GeOlOGICAL SuRVEY, FEDERAL LANDS AND INDIAN RESERVATIONS (2005), http://nationalmap.gov/ small_scale/printable/images/pdf/fedlands/fedlands3.pdf [https://perma.cc/8G9GRL8P]. Lee Ferry's significance with regard to basinwide water supplies and the Colorado River Compact's apportionment is respectively discussed infra sections II.B. 3 and III.B.

37. MacDonnell, supra note 11 , at 6.

38. Colorado River Governance Initiative, Getches-Wilkinson CENTER FOR NATURAL RESOURCEs, ENERgy AND THE ENVIRONMENT, RETHINKING THE Future of THE COLORADO River, DRAFT INTERIM REPORT OF THE COLORADO RIVER GOVERNANCE INITIATIVE 3 fig.1 (2010), http://scholar.law.colorado.edu/cgi/ viewcontent.cgi?article $=1013 \&$ context=books_reports_studies [https://perma.cc/ 54NW-KBAD] [hereinafter CRGI REPORT].

39. See TECHNICAL REPORT B, supra note 8, at B-22 (noting Green River contributes 33 percent of Colorado River's natural flow).

40. See generally JOHN WESLEY POWELl, THE EXPLORATION OF THE COLORADO RIVER AND ITS CANYONS (1875).

41. See TECHNICAL REPORT B, supra note 8, at B-22 (noting San Juan River contributes 13 percent of Colorado River's natural flow).

42. PHASE I REPORT, supra note 5, at 1; U.S. and World Population Clock, U.S. CENSUS BUREAU, http://www.census.gov/popclock/ (last visited Aug. 26, 2016) 
metropolitan areas outside the basin import this lifebloodincluding Los Angeles, San Diego, Denver, Salt Lake City, and Albuquerque-while in-basin counterparts like Phoenix and Las Vegas are comparably reliant. 43 Yet it is agriculture that receives the lion's share. Approximately 70 percent of these flows irrigate nearly four and a half million acres in and around the basin. ${ }^{44}$ Of course, these municipal and agricultural uses should not obscure wide-ranging non-consumptive uses of system water, including environmental flows for habitat and species, soul-enriching, lucrative recreation, and large-scale hydropower generation. ${ }^{45}$

\section{B. A Sense of Pace}

With so much to offer so many, it is perhaps unsurprising during the Anthropocene ${ }^{46}$ for the Colorado River Basin and its environs to have been the site of mind-bending human alteration, habitation, and utilization since Meyers's scholarship commensurate with the Big Buildup. Plumbing the river system, and peopling the landscape with its flows, have been integral parts of this socio-ecological pattern. So too has a dire result involving the interplay of these variables: "point tipping" with regard to water supplies and demands.

\section{Plumbing}

"Unregulated, the Colorado River wouldn't be worth a good God damn to anybody." 47 Who else would have expressed himself in such artful terms but the Bureau of Reclamation's famous (in some quarters, infamous), irascible, and arguably most colorful of all commissioners, Floyd Dominy, a force of nature referred to throughout the agency simply as the

\footnotetext{
[https://perma.cc/T5LQ-YUVD].

43. PHASE I REPORT, supra note 5, at 1-2.

44. Id.

45. $I d$.

46. This term is a proposed label for the current epoch in geological time. It generally accounts for the pervasive impacts of human activities on the biosphere. See, e.g., Joseph Stromberg, What is the Anthropocene and Are We in It?, SMITHSONIAN MAG., http://www.smithsonianmag.com/science-nature/what-is-theanthropocene-and-are-we-in-it-164801414/?no-ist (last visited Oct. 24, 2016) [https://perma.cc/MLE2-N49W].
}

47. John MCPhee, EnCounters With the ARCHDRUid 240 (1971). 
"Kmish," who held his office from 1959 to 1969 during one of the Bureau's liveliest periods. ${ }^{48}$ And who else would have elicited such vitriol but the "archdruid" David BrowerExecutive Director of the Sierra Club during a stint marked largely by epic battles between the conservation movement and the Bureau over proposed construction of Echo Park Dam in Dinosaur National Monument, and Bridge Canyon and Marble Canyon dams in the Grand Canyon. ${ }^{49}$ These dam fights grew out of Congress's passage of the Colorado River Storage Project Act in 1956 and the Colorado River Basin Project Act in 1968. The projects brought into being by these laws completed the basin's plumbing system, and in so doing facilitated the varied aspects of the Big Buildup.

Only a snapshot of the plumbing system is possible here, but looking briefly at the Colorado River Storage Project Act, the projects it authorized-most notably, Lake Powell and Glen Canyon Dam-constitute "one of the most complex and extensive river resource developments in the world." 50

Located adjacent to the northern Arizona community of Page, Glen Canyon Dam is the third-highest concrete arch dam in the United States (only Hoover Dam and Dworshak Dam are higher), and backs up the nation's second-largest reservoir in terms of storage capacity (only Lake Mead has more) just upstream of Lee Ferry along the Colorado River. ${ }^{51}$ It might be impossible to find a more polarizing water project. Secretary Udall proclaimed Lake Powell "the most scenic and most beautiful manmade lake in the world" at Glen Canyon Dam's dedication in 1966, ${ }^{52}$ echoing Floyd Dominy's appraisals of the

48. Id. at 191; Commissioners of Reclamation, U.S. BUREAU OF RECLAMATION, http://www.usbr.gov/history/commiss.html (last visited Aug. 26, 2016) [https://perma.cc/8ZTX-PHDJ].

49. David Brower's "archdruid" title comes from MCPHEE, supra note 47. For excellent accounts of these dam fights, see MARK W. T. HARVEY, A SYMBOL OF WILDERNESS: ECHO PARK AND THE AMERICAN CONSERVATION MOVEMENT (1994), and Russell martin, A Story That Stands Like a Dam: Glen Canyon And THE STRUGGLE FOR THE SOUL OF THE WEST (1989).

50. UpPer Colorado River Commission, SiXTy-SEventh ANNUAL REPORT 31 (2015) (on file with author) [hereinafter UCRC 2015 REPORT].

51. See, e.g., List of Tallest Dams in the World, WIKIPEDIA, https://en.wikipedia.org/wiki/List_of_tallest_dams_in_the_world (last visited Aug. 26, 2016) [https://perma.cc/BBE2-YT76]; Upper Colorado Region, Colorado River Storage Project, Lake Powell, U.S. BUREAU OF RECLAMATION, http://www.usbr.gov/uc/rm/crsp/gc/lakepowell.html (last visited Aug. 26, 2016) [https://perma.cc/3NJZ-JXDL].

52. GLEN CANYON TRANSCRIPT, supra note 1 , at 3. 
reservoir as the "Jewel of the Colorado" and "Taj Mahal of America."53 In contrast, David Brower regarded the dam's existence-specifically, the fact that he did not fight its authorization in the Colorado River Storage Project Act-as "the greatest failure of his life." 54 In his assessment, "Lake Powell is a drag strip for power boats. It's for people who won't do things except the easy way. The magic of Glen Canyon is dead. It has been vulgarized. Putting water in the Cathedral in the Desert was like urinating in the crypt of St. Peter's." 55 Regardless of precisely where one falls between these two poles, it is plain that Glen Canyon Dam's completion in 1963, Lake Powell's filling in 1980, and the project's operation across and since this time period has worked monumental changes in and around the basin.

Although Glen Canyon Dam and Lake Powell mark the Colorado River Storage Project's centerpiece, the basin's history over the past half century also has involved construction and operation of three other major dam and reservoir projects noted earlier within the Upper Basin. Situated on the San Juan River in northern New Mexico, Navajo Dam and Reservoir again was the first project in this line, with the dam's completion and reservoir's filling occurring in 1963. ${ }^{56}$ Secretary Udall offered a prescient forecast at the dam's dedication the year prior: "Next year and the next and the next, we're going to have ceremonies like this in Arizona and Utah and Colorado. This is just the beginning." 57 President Kennedy, in turn, bore out the Secretary's message as one of his last official acts before the assassination in Dallas, visiting Salt Lake City on September 27, 1963, to press a key to start the first generator at Flaming Gorge Dam on the Green River just south of the Utah-Wyoming border. ${ }^{58}$ Lady Bird Johnson

53. U.S. Bureau of Reclamation, Lake Powell: Jewel of the Colorado (1965), https://www.usbr.gov/projects/pdf.php?id=227 [https://perma.cc/Z4F24PWT]; JEDEDIAH Rogers, U.S. BUREAU OF REClamation, Glen CANYON UNIT at 37 (2006), http://www.usbr.gov/projects/ImageServer?imgName=Doc 1232657383034.pdf [https://perma.cc/82N4-V4VD].

54. MCPHEE, supra note 47, at 163.

55. Id. at 240 .

56. Toni Linenberger, U.S. Bureau OF REClamation, The NAVAJo Unit at 12, 15 (1998), https://www.usbr.gov/projects/pdf.php?id=86 [https://perma.cc/ VY2Q-5WB3].

57. NAVAJO TRANSCRIPT, supra note 25 , at 14.

58. Roy Webb, Lost Canyons of the Green River: The Story Before FLAMING GORGE DAM 121 (2012). 
dedicated the dam the following year. ${ }^{59}$ Finally, a trio of dams and reservoirs along the Gunnison River in central Colorado, the Aspinall Unit, was the fourth and final project to be built, emerging between 1966 and 1976. ${ }^{60}$ Beyond these large-scale dams and reservoirs, the Colorado River Storage Project Act, coupled with legislation in 1962 and 1964, authorized seventeen "participating projects,"61 including two major transbasin diversions: the Central Utah Project serving Salt Lake City and the Wasatch Front, and the San-Juan Chama Project serving Albuquerque and Santa Fe.

Just as the Colorado River Storage Project Act featured Glen Canyon Dam and Lake Powell as its chief components, so too did the Colorado River Basin Project Act in 1968 pave the way for a proverbial Giant Octopus: the Central Arizona Project (CAP), "[t]he most expensive Bureau of Reclamation project ever constructed." 62 The CAP transports up to 1.5 maf annually from the Colorado River mainstream at Lake Havasu through a 336-mile aqueduct system serving the cities of Phoenix and Tucson as well as a host of agricultural water users and American Indian tribes. ${ }^{63}$ The CAP's story is full of historical morsels, including its roots in George H. Maxwell's pitch for an Arizona Highline Canal in 1922 (a "mad man's dream"); its role three decades later in precipitating Arizona $v$. California ${ }^{64}$ in the Supreme Court; and, contemporaneous with Meyers's scholarship, its post-Arizona $v$. California instigation of the Grand Canyon dam fights during the 1960s. ${ }^{65}$ The Colorado River Basin Project Act brought the CAP to fruition. Three years after the Act's passage, the Central Arizona Water

59. Toni Linenberger, U.S. BUREau of Reclamation, The Flaming Gorge UNIT at 19 (1998), http://www.usbr.gov/projects/ImageServer?imgName=Doc 1272984854191.pdf [https://perma.cc/34EJ-KRYX].

60. See ZACHARY REDMOND, U.S. BUREAU OF REClamation, WAYNE ASPINALL UNIT at 30, 39, 50 (2000), http://www.usbr.gov/projects/ ImageServer?imgName=Doc_1272984948607.pdf [https://perma.cc/Z7G4-FL7Y].

61. UCRC 2015 REPORT, supra note 50, at 51 tbl.6.

62. JENNIFER ZUNigA, U.S. BUREAU OF RECLAMATION, The CENTRAL ARIZONA PROJECT 2 (2000), http://www.usbr.gov/projects/ImageServer?imgName=Doc_ 1303158888395.pdf [https://perma.cc/6CJ9-V7Q8]. See generally RICH JOHNSON, THE CENTRAL ARIZONA PROJECT, 1918-1968 (1977) (chronicling CAP history).

63. Lower Colorado Region, Phoenix Area Office - Facilities, Central Arizona Project, U.S. BUREAU OF RECLAMATION, http://www.usbr.gov/lc/phoenix/projects/ capproj.html (last visited Aug. 9, 2016) [https://perma.cc/NP9K-8PLR].

64. 373 U.S. 546 (1963).

65. ZUNIGA, supra note 62, at 17-30; MARTIN, supra note 49, at 256-57. 
Conservation District (CAWCD) originated to contract with the federal government for the project's construction-a multidecade process commenced in $1973 .{ }^{66} \mathrm{CAP}$ water subsequently reached Phoenix and Tucson for the first time in 1985 and 1993, respectively, with the latter deliveries marking the project's "substantial completion." 67

Far more could be said about the authorization, construction, and operation of the Colorado River Storage Project and CAP over the past half century, and Part III covers some of this additional ground. For now, it is fitting to shift from this infrastructure to a closely intertwined discussion of population growth by highlighting the fact that "no substantial reclamation projects have been authorized" within the Colorado River Basin since the CAP in 1968. ${ }^{68}$

\section{Peopling}

Water stored in, and delivered from, the foregoing water projects and their predecessors has grown human populations inside and adjacent to the Colorado River Basin just as it has grown crops. ${ }^{69}$ Demographic trends in the Basin States over the past several decades are eye popping. This sentiment applies to the extent and rate of population growth as well as to the degree of urbanization. A brief quantitative overview of these trends appears below.

Table 1 offers an initial regional perspective on the Basin States' "peopling" since The Colorado River. ${ }^{70}$ In a nutshell, the collective trend involves more than a doubling of the basin

66. ZUNIGA, supra note 62 , at $32-34$.

67. Id. at $34-35$.

68. Id. at 52 .

69. See, e.g., WILKINSON, supra note 22, at xii (describing the Big Buildup as a concerted campaign for "rapid, wholesale development of the energy and water of the Colorado Plateau," and noting how the campaign transformed modern Southwest "from a back-water region of 8 million people at the end of World War II into a powerhouse of 32 million" at millennium's turn).

70. All regional figures are calculated from data at Intercensal Estimates of the Total Resident Population of States: 1960 to 1970, PopUlation Distribution BRANCH, U.S. CENSUS BUREAU, http://www.census.gov/popest/data/state/asrh/ 1980s/tables/st6070ts.txt (last visited Aug. 9, 2016) [https://perma.cc/A325-2AQS]; Annual Estimates of the Resident Population for the United States, Regions, States, and Puerto Rico: April 1, 2010 to July 1, 2015, PopUlation Division, U.S. CENSUS BUREAU, www.census.gov/popest/data/national/totals/2015/index.html (last visited Aug. 9, 2016) [https://perma.cc/JLH8-Z6X8]. 
states' population at a triple-digit rate greater than twice the national average. California's addition of roughly twentymillion residents is perhaps most remarkable in terms of net growth, but Nevada's more than quintupling population cannot go unmentioned.

Table 1. Basin State Population Growth

\begin{tabular}{|l|r|r|r|r|}
\hline & \multicolumn{1}{|c|}{$\begin{array}{c}1966 \\
\text { Population }\end{array}$} & $\begin{array}{c}\text { 2015 } \\
\text { Population }\end{array}$ & Net Growth & \multicolumn{1}{c|}{$\begin{array}{c}\text { Growth } \\
\text { Rate }\end{array}$} \\
\hline Arizona & $1,614,000$ & $6,828,065$ & $5,214,065$ & $323 \%$ \\
\hline California & $18,858,000$ & $39,144,818$ & $20,286,818$ & $108 \%$ \\
\hline Colorado & $2,007,000$ & $5,456,574$ & $3,449,574$ & $172 \%$ \\
\hline Nevada & 446,000 & $2,890,845$ & $2,444,845$ & $548 \%$ \\
\hline New Mexico & $1,007,000$ & $2,085,109$ & $1,078,109$ & $107 \%$ \\
\hline Utah & $1,009,000$ & $2,995,919$ & $1,986,919$ & $197 \%$ \\
\hline Wyoming & 323,000 & 586,107 & 263,107 & $81 \%$ \\
\hline Basin State Total & $25,264,000$ & $59,987,437$ & $34,723,437$ & $137 \%$ \\
\hline U.S. Total & $195,501,000$ & $321,418,820$ & $125,917,820$ & $64 \%$ \\
\hline
\end{tabular}

Although insightful in many ways, one shortcoming of these regional figures is their lack of precision. Specifically, the figures account for each Basin State's entire population as opposed to solely those segments either (1) located within the Colorado River Basin, or (2) located outside the basin but to which water from the Colorado River System is exported.

Tables 2 and 3 offer a lens on the former group (i.e., inbasin population growth). The most current Bureau of Reclamation data addressing these trends illuminate in-basin population growth within the Upper Basin from 1976 to 2014, ${ }^{71}$ and within the Lower Basin from 1976 to 2005. ${ }^{72}$ Three

71. U.S. Bureau of Reclamation, Provisional Upper Colorado River BAsin CONSUMPTIVE UsES AND LOSSES REPORT 2011-2015 at 18 tbl.UC-8 (2016), http://www.usbr.gov/uc/library/envdocs/reports/crs/pdfs/cul2011-15prov.pdf [https://perma.cc/V4TB-9B5X] [hereinafter 2015 CUL REPORT]; U.S. BUREAU OF ReClamation, Colorado RIVER System CONSumptive Uses and LOSSES REPORT 1976-1980 at 31 tbl.UC-8 (1980), http://www.usbr.gov/uc/library/envdocs/ reports/crs/pdfs/1976.pdf [https://perma.cc/4TZ3-G6WK] [hereinafter 1980 CUL REPORT].

72. U.S. Bureau of Reclamation, Colorado River Basin Consumptive UsEs AND LOSSES REPORT 2001-2005 at 42 tbl.LC-10 (2012), http://www.usbr.gov/uc/library/envdocs/reports/crs/pdfs/cul2001-05.pdf [https://perma.cc/72VK-3CFD] [hereinafter 2005 CUL REPORT]; 1980 CUL 
highlights are worth mentioning: (1) a more than doubling of the Upper Basin population, (2) a more than tripling of the Lower Basin population, and (3) a greater than fourfold increase in both Nevada's and Utah's populations within the Lower Basin.

Table 2. Upper Basin In-Basin Population Growth

\begin{tabular}{|l|r|r|r|r|}
\hline & 1976 Population & 2014 Population & Net Growth & Growth Rate \\
\hline Arizona & 31,800 & 46,600 & 14,800 & $47 \%$ \\
\hline Colorado & 243,300 & 594,500 & 351,200 & $144 \%$ \\
\hline New Mexico & 83,100 & 155,200 & 72,100 & $87 \%$ \\
\hline Utah & 77,500 & 121,800 & 44,300 & $57 \%$ \\
\hline Wyoming & 43,700 & 73,700 & 30,000 & $69 \%$ \\
\hline Total & 479,400 & 992,000 & 512,600 & $107 \%$ \\
\hline
\end{tabular}

Table 3. Lower Basin In-Basin Population Growth

\begin{tabular}{|l|r|r|r|r|}
\hline & 1976 Population & 2005 Population & Net Growth & Growth Rate \\
\hline Arizona & $2,221,000$ & $6,257,400$ & $4,036,400$ & $182 \%$ \\
\hline California & 21,300 & 29,800 & 8,500 & $40 \%$ \\
\hline Nevada & 364,900 & $2,055,800$ & $1,690,900$ & $463 \%$ \\
\hline New Mexico & 51,200 & 76,100 & 24,900 & $49 \%$ \\
\hline Utah & 20,100 & 102,400 & 82,300 & $409 \%$ \\
\hline Total & $2,678,500$ & $8,521,500$ & $5,843,000$ & $218 \%$ \\
\hline
\end{tabular}

A major reason for the in-basin population growth disparity within the Upper Basin versus Lower Basin is that, although the figures above account for Lower Basin metropolises like Las Vegas and Phoenix, the figures do not address their Upper Basin counterparts like Denver, Salt Lake City, and Albuquerque, as the latter fall outside the basin. Table 4 reveals the intense growth within these metropolitan areas across the past five decades. As just two vivid examples, consider Las Vegas's almost sevenfold population increase, and the nearly seven-million additional residents now inhabiting the southern California coastal plain. 
Table 4. Metropolitan Area Population Growth

\begin{tabular}{|c|c|c|c|c|}
\hline & $\begin{array}{c}1970 \\
\text { Population }\end{array}$ & $\begin{array}{c}2015 \\
\text { Population }\end{array}$ & $\begin{array}{c}\text { Net } \\
\text { Growth }\end{array}$ & $\begin{array}{c}\text { Growth } \\
\text { Rate }\end{array}$ \\
\hline Albuquerque, $\mathrm{NM}^{73}$ & 359,024 & 907,301 & 548,277 & $153 \%$ \\
\hline Denver, $\mathrm{CO}^{74}$ & $1,118,563$ & $2,814,330$ & $1,695,767$ & $152 \%$ \\
\hline Las Vegas, $\mathrm{NV}^{75}$ & 273,288 & $2,114,801$ & $1,841,513$ & $674 \%$ \\
\hline Los Angeles, $\mathrm{CA}^{76}$ & $8,463,215$ & $13,340,068$ & $4,876,853$ & $58 \%$ \\
\hline Phoenix, $\mathrm{AZ}^{77}$ & $1,039,807$ & $4,574,531$ & $3,534,724$ & $340 \%$ \\
\hline Salt Lake City, UT ${ }^{78}$ & 480,152 & $1,170,266$ & 690,114 & $144 \%$ \\
\hline San Diego, $\mathrm{CA}^{79}$ & $1,357,854$ & $3,299,521$ & $1,941,667$ & $143 \%$ \\
\hline Tucson, $\mathrm{AZ}^{80}$ & 351,667 & $1,010,025$ & 658,358 & $187 \%$ \\
\hline
\end{tabular}

Implicit in all of the growth figures above is an urbanization trend apparent to varied degrees across the Basin States over the past several decades. Table 5 evidences this trend by identifying the percentages of the states' populations residing in urban areas as of 1970 and 2010.81 Although the

73. Population Data for Albuquerque, NM, ReAl Estate CTR., TeX. A\&M UNIV., https://www.recenter.tamu.edu/data/population/\#!/msa/Albuquerque\%2C_ NM (last visited Aug. 9, 2016) [https://perma.cc/E6HT-2SPA].

74. Population Data for Denver-Aurora-Lakewood, CO, REAL EsTATE CTR., TEX. A\&M UNIV., https://www.recenter.tamu.edu/data/population/\#!/msa/DenverAurora-Lakewood\%2C_CO (last visited Aug. 9, 2016) [https://perma.cc/L5DMRLFN].

75. Population Data for Las Vegas-Henderson-Paradise, NV, REAL Estate CTR., TEX. A\&M UNIV., https://www.recenter.tamu.edu/data/population/\#!/msa/ Las_Vegas-Henderson-Paradise\%2C_NV (last visited Aug. 9, 2016) [https://perma.cc/4SAN-9XBM].

76. Population Data for Los Angeles-Long Beach-Anaheim, CA, REAL Estate CTR., TEX. A\&M UNIV., https://www.recenter.tamu.edu/data/population/\#!/msa/ Los_Angeles-Long_Beach-Anaheim\%2C_CA (last visited Aug. 9, 2016) [https://perma.cc/G7J6-CTQE].

77. Population Data for Phoenix-Mesa-Scottsdale, AZ, REAL Estate CTR., TEX. A\&M UNIV., https://www.recenter.tamu.edu/data/population/\#!/msa/PhoenixMesa-Scottsdale\%2C_AZ (last visited Aug. 9, 2016) [https://perma.cc/9KKWHRYC].

78. Population Data for Salt Lake City, UT, ReAl Estate CTR., TeX. A\&M UNIV., https://www.recenter.tamu.edu/data/population/\#!/msa/Salt_Lake_City\% 2C_UT (last visited Aug. 9, 2016) [https://perma.cc/KV5K-W5NU].

79. Population Data for San Diego-Carlsbad, CA, Real Estate Ctr., TeX. A\&M UNIV., https://www.recenter.tamu.edu/data/population/\#!/msa/San_DiegoCarlsbad\%2C_CA (last visited Aug. 9, 2016) [https://perma.cc/RPP5-VY42].

80. Population Data for Tucson, AZ, Real Estate CTR., TeX. A\&M Univ., https://www.recenter.tamu.edu/data/population/\#!/msa/Tucson\%2C_AZ (last visited Aug. 9, 2016) [https://perma.cc/S5VG-3NQV].

81. All urbanization figures are calculated from data at Urban and Rural 
starkest increases have taken place in Nevada and Utah, the critical insight is that the pattern of urbanization has been uniform across the states.

Table 5. Basin State Urbanization

\begin{tabular}{|l|r|r|r|}
\hline & $\begin{array}{c}\text { 1970 Urban } \\
\text { Percentage } \\
\text { of Population }\end{array}$ & $\begin{array}{c}\text { 2010 Urban } \\
\text { Percentage } \\
\text { of Population }\end{array}$ & \multicolumn{2}{|c|}{$\begin{array}{c}\text { Percentage } \\
\text { Increase }\end{array}$} \\
\hline Arizona & $80 \%$ & $90 \%$ & $10 \%$ \\
\hline California & $91 \%$ & $95 \%$ & $4 \%$ \\
\hline Colorado & $79 \%$ & $86 \%$ & $7 \%$ \\
\hline Nevada & $81 \%$ & $94 \%$ & $13 \%$ \\
\hline New Mexico & $70 \%$ & $77 \%$ & $11 \%$ \\
\hline Utah & $80 \%$ & $91 \%$ & $4 \%$ \\
\hline Wyoming & $61 \%$ & $65 \%$ & \\
\hline
\end{tabular}

This "peopling" survey is necessarily concise, but it should be flagged in closing that the dynamic, urbanizing growth in and around the basin since The Colorado River is not projected to cease in coming years, at least according to the Bureau of Reclamation's Basin Study. It forecast 49.3 to 76.5 million people will reside in the basin or export areas by 2060,82 compared to an estimated 40 million residents as of 2015.83 To what extent does this projection align with water supply and demand conditions at present and looking forward? An answer appears below that may engender skepticism.

\section{Point Tipping}

An imbalance between water supplies and demands in the Colorado River Basin has been on the radar for decades. Published in December 2012, the Basin Study offered a detailed contemporary perspective on this subject, but it has been a major concern since at least as far back as the Pacific Southwest Water Plan's release in 1964 just prior to Meyers's

Population: 1900 to 1990, U.S. CENSUs BUREAU, https://www.census.gov/ population/censusdata/urpop0090.txt (last visited Aug. 9, 2016) [https://perma.cc/2X3Q-UEBQ]; 2010 Census Urban Lists Record Layouts, U.S. CENSUs BUREAU, https://www.census.gov/geo/reference/ua/urban-rural-2010.html (last visited Aug. 9, 2016) [https://perma.cc/ T2VP-RPZ9].

82. TECHNICAL REPORT C, supra note 35, at C-21.

83. Id. at C-20. 
scholarship. ${ }^{84}$ The Basin Study provided a wealth of information in this vein from both retrospective and prospective angles. To date, it is "the most comprehensive basin-wide analysis ever undertaken within the Department of the Interior," 85 and also remarkably "the first Basin-wide study conducted by the Basin States and Reclamation that considers the potential influence of climate change on future water supply."86 Figure 2 largely captures the study's upshot for present purposes. ${ }^{87}$ Following a steadily increasing trend over the past half-century, water demands have exceeded water supplies on average since roughly the historic drought's onset in 2000, and this imbalance is projected to widen in coming decades - albeit by an undetermined margin. The material below highlights key details of this point-tipping pattern and projection.

84. See generally U.S. BUREAU of REClamation, Colorado River Basin Water Supply AND Demand Study, Study Report app. 3 Summary of Past COLORADO RIVER BASIN PLANNING STUDIES (2012), http://www.usbr.gov/lc/ region/programs/crbstudy/finalreport/Study\%20Report/StudyReport_Appendix3_F INAL.pdf [https://perma.cc/2JSE-SMKZ] [hereinafter STUDIES SUMMARY] (discussing Colorado River Basin water supply and demand studies preceding Basin Study); U.S. Bureau of Reclamation, Pacific Southwest Water Plan (1964), https://www.usbr.gov/lc/region/programs/crbstudy/PSWPRptJan64.pdf [https://perma.cc/83WR-C47S] [hereinafter WATER PLAN].

85. U.S. Bureau of Reclamation, Moving Forward to Address The CHALlenges IDENTIFIED IN THE COLORADO RIVER BASIN WATER SUPPLY AND DEMAND STUDY 2 (2014), http://www.usbr.gov/lc/region/programs/crbstudy/ MovingForward/FactSheet_MovingForward.pdf [https://perma.cc/YD42-X22P].

86. GOVERNOR's RePRESENTATIVES ON COLO. River OPERATIONS, STATES OF Ariz., Cal., Colo., Nev., N.M., Utah, and Wyo., The Seven Basin States' COMMITMENTS to FUtURE ACTIONS Following RELEASE OF THE BASIN STUDY 1 (2012), http://crc.nv.gov/files.php/news/6bf8f2168bbecfe468dbfa797ccf0b33/CRCNews-2012-12-12 [https://perma.cc/X8WP-C5UD] [hereinafter BASIN STATES' COMMITMENTS].

87. PHASE I REPORT, supra note 5, at 1-5 fig.1-2. This figure's treatment of Lower Basin tributaries poses a host of methodological issues. See generally U.S. Bureau of REClamation, Colorado River Basin Water Supply and DEMand Study, TEChNical Report C app. C11 Modeling of Lower Basin TRIBUTARIES IN THE COLORADO RIVER Simulation SYSTEM (2012), http://www.usbr.gov/lc/ region/programs/crbstudy/finalreport/Technical\%20Report\%20C\%20-\%20Water\% 20Demand\%20Assessment/TR-C_Appendix11_FINAL.pdf [https://perma.cc/6RPQTN52] [hereinafter TRIBUTARIES APPENDIX] (describing issues). 
Figure 2. Historical Supply and Use and Projected Future Colorado River Basin Water Supply and Demand ${ }^{1}$

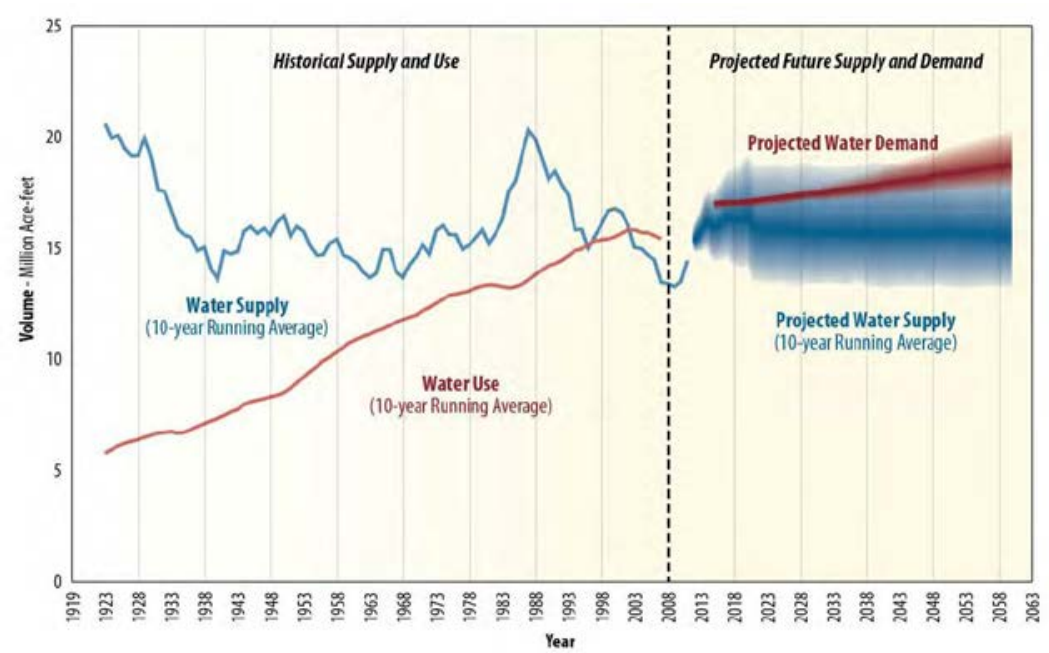

'Water use and demand include Mexico's allotment and losses such as those due to reservoir evaporation, native vegetation and operational inefficiencies.

Demands for Colorado River System water have increased markedly since The Colorado River. Figure 2 depicts this pattern as a decadal average. ${ }^{88}$ Excluding Lower Basin tributaries, ${ }^{89}$ annual basinwide consumptive uses and losses (including treaty deliveries to Mexico) grew from "approximately 13 maf to over 15 maf, an increase of about 14 percent," between 1971 and 2010.90 The apex occurred in 2000 and 2001-when demands exceeded 16 maf-but the historic drought's onset in 2000 resulted in these levels falling to slightly above 15 maf by $2010 .{ }^{91}$ More important than the apex are the facts that annual demands exceeded supplies on average for the first time in the basin's history during the late 1990s, and that this pattern has persisted across the past

88. See also STUDY REPORT, supra note 6, at SR-4 fig.1 (depicting pattern on annual basis).

89. See generally TRIBUTARIES APPENDIX, supra note 87, at C11-9 to -16 (identifying historical consumptive uses and losses along Lower Basin tributaries).

90. TECHNICAL REPORT C, supra note 35, at C-6.

91. Id. at C-8 fig.C-3; see also U.S. BUREAU OF RECLAMATION, SECURE WATER ACT SECTION 9503(C)-RECLAMATION Climate CHANGE AND WATER 2016 3-1 (2016), http://www.usbr.gov/climate/secure/docs/2016secure/2016SECURE Report.pdf [https://perma.cc/AU6J-H2UZ] (noting basinwide consumptive uses and losses averaged approximately 15.0 maf from 2000 to 2012). 
decade. ${ }^{92}$ With regard to water uses, two patterns are notable: (1) an increase in municipal and industrial uses stemming from population growth, and (2) a stabilization and recent reduction in agricultural uses due to drought. ${ }^{93}$ Whether deemed credible or not, ${ }^{94}$ the Basin Study suggested these trends will not abate. As Figure 2 generally displays, the study projected basinwide consumptive uses and losses-again, excluding Lower Basin tributaries-ranging from 17.7 to 20.1 maf by 2060, and involving overall increases in municipal and industrial demands and corresponding decreases in agricultural demands. 95

The water supply picture in the Colorado River Basin looks much different. It, of course, implicates climate change, both historical and future. Flow levels at Lee Ferry are a critical metric in this regard because roughly 92 percent of the basin's natural flow-as measured at Imperial Dam above the Gila River's mouth—originates upstream of Lee Ferry in the Upper Basin. ${ }^{96}$

Figure 2 depicts the historical supply situation on a decadal basis. Drawing on a historical record from 1906 to 2015, natural flows at Lee Ferry averaged approximately 14.8 maf per year. ${ }^{97}$ As mentioned earlier, the period from 2000 to 2015 has been "the driest 16-year period in the past 100 years and one of the driest 16-year periods in the past 1,200 years." 98 More specifically, figures from the Upper Colorado River Commission estimate natural flows at Lee Ferry averaged roughly 12.44 maf per year from 2000 to 2015. ${ }^{99}$ The temperature trend noted above bears directly on this pattern. From 1895 to 2005, average surface air temperature in the

92. PHASE I REPORT, supra note 5, at 1-5 fig.1-2.

93. TECHNICAL REPORT C, supra note 35, at C-8 fig.C-3, C-9 fig.C-4. Drought has reduced water availability and thus contributed to decreases in basinwide agricultural use. Id. at C-8 fig.C-3.

94. See Baker Letter, supra note 10, at 2 (describing water demand forecasts as "inflated").

95. For more detailed descriptions of these projections, see TECHNICAL REPORT C, supra note 35, at C-23, C-25 fig.C-8, C-30 fig.C-12, C-32 fig.C-13.

96. TECHNICAL REPORT B, supra note 8, at B-22.

97. Open Data, supra note 9; see also UCRC 2015 REPORT, supra note 50, at 25 tbl.3 (indicating natural flows at Lee Ferry averaged 14.6 maf from 1896 to 2015). These flows were highly variable, ranging from 5.6 maf in 1977 to 25.2 maf in 1984. TECHNICAL REPORT B, supra note 8, at B-22.

98. Open Data, supra note 9.

99. UCRC 2015 REPORT, supra note 50, at 25 tbl.3. 
basin rose 2.5 degrees Fahrenheit (1.39 degrees Celsius), with a roughly 2.0 degree Fahrenheit (1.11 degree Celsius) increase occurring between 1970 and 2005. 100 No significant long-term annual precipitation trend is apparent, but "annual variability appears to be increasing." 101

Looking ahead, one of the Basin Study's four projection scenarios, the Downscaled GCM Scenario, addressed climate change's potential impacts on basinwide water supplies. A "strong continued warming" trend appears in this scenario. ${ }^{102}$ It involves a median increase in annual temperature of about 2.34 degrees Fahrenheit (1.3 degrees Celsius) by 2025, 4.32 degrees Fahrenheit (2.4 degrees Celsius) by 2055, and 5.94 degrees Fahrenheit (3.3 degrees Celsius) by 2080, with the Upper Basin projected to warm more than the Lower Basin. ${ }^{103}$ As for average annual precipitation, the projections do not suggest a basinwide trend, but decreases of up to $10 \%$ are anticipated in much of the Lower Basin, while increases of up to $10 \%$ are expected in the Upper Basin, across the latter half of the century. ${ }^{104}$ Ultimately, the mean projection in the Downscaled GCM scenario is that natural flows at Lee Ferry will average 13.7 maf annually from 2011 to 2060 -an $8.7 \%$ decrease from observed flows in the historical record-although the Basin Study also described "the median of the projections is nearly 1.0 maf lower (annual flow of around $12.7 \mathrm{maf}$ ) than the mean." 105 Notwithstanding these mean and median figures, the Basin Study acknowledged, "[r]ecent studies have postulated that the average yield of the Colorado River could be reduced by as much as 20 percent due to climate change," 106 and researchers have suggested reductions ranging from $6 \%$ to $45 \%$ by 2050.107

In sum, the Basin Study marked "the next logical step"108 in five decades of studies reflecting persistent concerns over

\footnotetext{
100. TECHNICAL REPORT B, supra note 8, at B-16 fig.B-7.

101. Id. at B-16.

102. Id. at B-51.

103. Id. at B-51 to -52, B-53 fig.B-37, B-54 fig.B-38.

104. See $i d$. at B-52, B-54 fig.B-38, B-55 fig.B-39 (addressing projected precipitation from 2041 to 2095).

105. Id. at B-65. The median is subsequently noted in tabular form as 13.6 maf. $I d$. at B-81 tbl.B-2.

106. STUDY REPORT, supra note 6, at SR-6.

107. Baker Letter, supra note 10, at 1.

108. STUDIES SUMMARY, supra note 84, at SR3-12.
} 
water supply and demand imbalances within the Colorado River Basin. As highlighted above, steadily increasing demands since publication of Meyers's scholarship resulted, for the first time in the basin's history, in average annual demands exceeding supplies over the past two decades, initially in the late 1990s followed by a rebound, and consistently across the past decade during the historic drought. When the drought will relent, and what "normal" flows will look like moving forward, are clutch matters for the imbalance's future scope. That said, the unprecedented intersection and inversion of the supply and demand lines in recent years alone underpins this section's heading of "point tipping." This reality is the Law of the River's legacy - the heritage of a labyrinthine body of laws whose potency in molding our socio-ecological systems within and adjacent to the basin ironically correlates with widespread cultural invisibility and misunderstanding regarding the content and operation of these laws. The next Part aims, in some small measure, to lift this veil.

\section{EVOLUTION OF THE INTERNATIONAL \& INTERSTATE ALLOCATION FRAMEWORK}

The Colorado River Basin and Law of the River share a reciprocal relationship. While the Law of the River has facilitated the vast scope of changes in and around the basin touched on above, these changes likewise have spurred the Law of the River's development in myriad ways detailed below. Given this dynamic, any attempt to chronicle how the Law of the River has evolved since Meyers's scholarship necessarily involves some narrowing. In this case, my coverage is woven around the unabating topic of apportionment that five decades ago drove Meyers's work. As mentioned earlier, Meyers's articles appeared at a key point in the Law of the River's history, emerging between the Supreme Court's Arizona $v$. California decision in 1963 and Congress's passage of the Colorado River Basin Project Act in 1968. While the latter shored up an infrastructural and operational base, the former announced (or arguably clarified) the fourth and final apportionment of the international and interstate allocation framework. Meyers again illuminated the legal histories, doctrinal features, and perplexities of this framework's nested apportionments in the U.S.-Mexico Treaty, Colorado River 
Compact, Upper Colorado River Basin Compact (Upper Basin Compact), and Arizona v. California decree.

This Part revisits these apportionments fifty years later. It clarifies precisely how they have adapted to the changes discussed in the previous Part, particularly throughout the historic drought. Taken together, these adaptations reveal an iterative wave of common patterns. Alluded to in the Introduction, Part IV synthesizes these patterns from retrospective and prospective angles. In short, they encompass the diverse milestones chronicled in the pages that follow, including the formulation of reservoir operating regimes as tools for implementing the apportionments and managing conflicts surrounding their core provisions, as well as the proliferation of measures aimed at avoiding or mitigating constraints on consumptive use along the Lower Colorado River. These are the prevalent threads to discern within the weave.

\section{A. U.S.-Mexico Treaty}

"Certainly we should deal with Mexico as a friend and not at arm's length. But when we make a treaty about water, we are dealing with the lifeblood of the West and shaping its whole destiny."109 Former President Herbert Hoover offered these remarks in 1945 during senatorial debates over ratification of a treaty governing the Colorado River that had been formed by U.S. and Mexican diplomats the year prior. ${ }^{110}$ The treaty prescribes an international apportionment that has evolved in a host of ways since its inception. Given this Article's focus on the Law of the River's international and interstate allocation framework, the material below outlines the apportionment and addresses the emergence in recent years of binational shortage sharing and water storage arrangements designed to implement and navigate the apportionment in the face of low flows and reservoir levels. As will become clear, these arrangements stem directly from the historic drought and

109. Ray Lyman Wilbur \& Northcutt Ely, The Hoover Dam Documents 159 (1948), http://www.riversimulator.org/Resources/LawOfTheRiver/ HooverDamDocs/HooverDam1948.pdf [https://perma.cc/EB3L-4PVB] [hereinafter HOOVER DAM DOCUMENTS].

110. Treaty, supra note 19. The treaty also governs the Rio Grande and the Tijuana River. $I d$. 
persistent treaty ambiguities elucidated expertly by Meyers fifty years ago.

\section{International Apportionment}

By signing the U.S.-Mexico Treaty on February 3, 1944, "the two countries...ended nearly a half century of controversy by agreeing to divide the waters of the Colorado River."111 Complementing Meyers's insightful co-authored piece, the premier Colorado River historian, the late Norris Hundley, Jr., produced rich scholarship on the treaty's protracted consummation. ${ }^{112}$ As eventually forged two decades following the Colorado River Compact's drafting in 1922, the treaty's international apportionment did not-at least according to former President Hoover-resemble anything the compact negotiators had envisioned. ${ }^{113}$ Nonetheless, the apportionment has remained durable for over seventy years, imposing on the United States a "national obligation"114 regarded as the Law of the River's highest priority. ${ }^{115}$

Article 10 of the treaty is the international apportionment's core. ${ }^{116}$ It provides Mexico with a perpetual, quantified apportionment of Colorado River water and imposes a corresponding delivery obligation on the United States. In relevant part, Article 10(a) states: "Of the waters of the Colorado River, from any and all sources, there are allotted to Mexico... [a] guaranteed annual quantity of 1,500,000 acrefeet... to be delivered in accordance with the provisions of Article 15." 117 The apportionment's volume and delivery obligation's perceived static nature were the fodder of President Hoover's critiques during the ratification debates. 118 He advocated instead for a pro-rata apportionment, but this

111. Norris Hundley, Jr., The West Against Itself: The Colorado River-An Institutional History, in New COURSES FOR THE COLORADO RIVER: MAJOR Issues FOR THE NEXT CENTURY 9, 25 (Gary D. Weatherford \& F. Lee Brown eds., 1986).

112. See generally id. at 25-28; NORRIS HUNDLEY, JR., DIVIDING THE WATERS: A Century of Controversy Between the United StATES AND MeXico (1966) (chronicling treaty formation).

113. Hoover DAm DocumenTS, supra note 109, at 161.

114. Colorado River Basin Project Act § 202, 43 U.S.C. $§ 1512$ (2012).

115. MacDonnell, supra note 11, at 21.

116. See Meyers \& Noble, supra note 14, at 388-93 (surveying treaty's Colorado River provisions).

117. Treaty, supra note 19, at art. 10(a).

118. HoOver DAM DocumenTS, supra note 109, at 161. 
advocacy did not take hold.

Yet the international apportionment does not wholly disregard allocational flexibility and risk. Article 10(b) contemplates augmentation and diminution of treaty deliveries. ${ }^{119}$ Regarding the latter, Article 10(b) addresses treaty delivery reductions as follows:

In the event of extraordinary drought or serious accident to the irrigation system in the United States, thereby making it difficult for the United States to deliver the guaranteed quantity of 1,500,000 acre-feet . . a year, the water allotted to Mexico... will be reduced in the same proportion as consumptive uses in the United States are reduced. ${ }^{120}$

Given the historic drought and projected climate changebased reductions in Lee Ferry flows, this text is critically important from an evolutionary perspective. Import does not equate with clarity, however, and this disjuncture has been the mother of invention.

\section{Of "Extraordinary Drought” \& Other Perplexities}

"There has, as yet, been no controversy between the United States and Mexico over the 'extraordinary drought' provision .... It takes little imagination, however, to foresee conflict if Mexico's deliveries are ever cut to less than 1.5 million acre-feet on the basis of article 10."121 Meyers made this remark in 1967, and both aspects of it ring true today. The United States has yet to invoke Article 10(b) to reduce treaty deliveries, including in response to the historic drought, and serious questions exist as to whether it can ever serve as a viable drought response mechanism. Three other seasoned Law of the River students shared Meyers's skepticism: President Hoover, Norris Hundley, Jr., and Northcutt Ely, lead counsel to the State of California in Arizona $v$. California and Executive Assistant to Interior Secretary Ray Lyman Wilbur during the

119. Treaty, supra note 19 , at art. 10(b). With regard to augmentation, the United States has committed to delivering up to 1.7 maf of treaty water annually, albeit with no vesting of rights to augmented flows. Id.

120. Id.

121. Meyers \& Noble, supra note 14, at 415. 
Hoover Administration. ${ }^{122}$ To understand why, consider Meyers's analytical framework: "[D]eliveries to Mexico will be reduced upon the occurrence of three conditions: (1) 'extraordinary drought' or 'serious accident to the irrigation system,' (2) 'difficulty' in making deliveries, and (3) reductions in consumptive uses in the United States." 123

What constitutes an "extraordinary drought" under Article 10(b)? A definition of the term does not appear in the treaty, and the historical record strongly suggests the drafters did not share a common understanding. As revealed by Hundley, U.S. State Department officials "eventually admitted that the treaty negotiators had made no attempt to agree on the meaning of 'extraordinary drought' or on who was to decide when such a drought had occurred." 124 At least two longstanding issues thus plague Article 10(b). One concerns the spatial and temporal characteristics for deeming a drought "extraordinary." 125 The other is procedural: By whom, and through what processes, is this determination to be made? ${ }^{126}$

Similar challenges extend from Article 10(b)'s other operative phrases outlined by Meyers. Not only does the provision hinge treaty delivery reductions on an extraordinary drought (or serious accident to the U.S. irrigation system), it also requires the event make it "difficult for the United States to deliver the guaranteed quantity of 1,500,000 acre-feet." 127 Again, by whom, and through what processes, is "difficulty" to be assessed? ${ }^{128}$ Further, how does the contemporary existence of over 60.0 maf of storage capacity in U.S. reservoirs bear on this determination? ${ }^{129}$ The latter consideration also plays into

122. See HoOver DAM Documents, supra note 109, at 161; HUNDLEY, supra note 112 , at $153,167,171$; NoRThCUTT Ely, Light on THE MEXICAN WATER Treaty From the Ratification Proceedings in Mexico: A Report to the COLORADO RIVER WATER USERS' ASSOCIATION 14-19 (1946), http://www.riversimulator.org/Resources/LawOfTheRiver/MexicanTreatyEly1946 CRWUAocr.pdf [https://perma.cc/86VX-G6P2].

123. Meyers \& Noble, supra note 14, at 411.

124. HUNDLEY, supra note 112, at 153.

125. For historically contrasting views on each dimension, see HUNDLEY, supra note 112, at 153, 167 (spatial dimension), and Meyers \& Noble, supra note 14, at 413 (temporal dimension).

126. HUNDLEY, supra note 112, at 153; see also ELY, supra note 122 , at 14 (no meeting of minds).

127. Treaty, supra note 19, at art. 10(b).

128. Meyers \& Noble, supra note 14, at 414.

129. See MacDonnell, supra note 11, at 10 (noting 60.0 maf of storage capacity). 
Article 10(b)'s text regarding treaty deliveries being "reduced in the same proportion as consumptive uses in the United States are reduced."130 The rub is that the Colorado River Storage Project's post-treaty construction suggests, "[i]f reservoirs in the United States happen to be relatively full at the beginning of the drought, it may take some time before low precipitation and runoff are reflected in decreased use." 131 At the end of the day, all of these perplexities-as well as a host of vexing administrative issues ${ }^{132}$ _significantly compound the "extraordinary drought" ambiguities.

"All told, it seems extremely unlikely that the United States can, as a practical matter, ever expect to rely on article 10 to reduce deliveries to Mexico."133 This quote captures Meyers's view in the final analysis. "[A]s a working clause on drought conditions, article 10 has little to recommend it," he opined, while adding on a realpolitik tip that "[a]s a clause purporting to offer some relief for the upper state and thus satisfying the local constituency, it may have served its purpose."134 What should be done in this situation, especially when the seemingly defunct provision addresses subjects like shortage sharing and risk allocation that are critical in the face of drought and climate change? Minute 319 reveals one pragmatic option.

\section{Minute 319: Pragmatism and Invention in Treaty Implementation}

In the context of the U.S.-Mexico Treaty and elsewhere, minutes serve to implement treaty provisions, rather than to amend them, ${ }^{135}$ and Minute 319 performs exactly this function

130. Treaty, supra note 19 , at art. 10(b).

131. Meyers \& Noble, supra note 14, at 413.

132. Examples of such issues include the following. Which specific consumptive uses must be accounted for when calculating the collective reduction of these uses in the United States and proportionate treaty delivery reductions? Is it possible to calculate, in an accurate and contemporaneous manner, the extent of reduced consumptive uses in the United States to provide the necessary baseline for proportionate treaty delivery reductions? Finally, if the answer to the previous question is "no," what time lag is inherent to this calculation, and how should it be handled? See id. at 414 (discussing administrative issues).

133. Id. at 415 .

134. Id.

135. Telephone Interview with Sally Spener, U.S. Sec'y, Int'l Boundary and Water Comm'n (July 16, 2015) [hereinafter Spener Interview]. 
with respect to treaty delivery reductions under the international apportionment. By its terms, the Minute disclaims affecting "the interpretation or application of the provisions of Article 10(b) of the 1944 Water Treaty, including reduction of water allotted to Mexico under Article 10(a)."136 Article 10 thus stands intact. For an interim period up to December 31, 2017, however, Minute 319 implements binational shortage sharing and water storage arrangements that constitute novel, potentially long-term precedents for navigating drought conditions without triggering Article 10(b). ${ }^{137}$ Each arrangement is considered in turn below.

The gist of Minute 319's shortage-sharing rules is that the amount of treaty water delivered annually from the United States to Mexico is permitted to diminish in sync with projected declines in Lake Mead's elevation. ${ }^{138}$ More precisely, Minute 319 establishes an incremental scale with three elevation tiers for Lake Mead-1,075 feet, 1,050 feet, and 1,025 feet-and three corresponding levels of treaty delivery reductions-50,000 acre-feet, 70,000 acre-feet, and 125,000 acre-feet-that will occur if the Bureau of Reclamation projects Lake Mead's elevation will be at or below these tiers as of January 1 each year. ${ }^{139}$ For example, if Lake Mead's projected elevation falls between 1,075 and 1,050 feet, treaty deliveries will be reduced 50,000 acre-feet. The shortage-sharing rules also require consultation between the U.S. Section of the International Boundary and Water Commission and the Bureau if Lake Mead's elevation lies below 1,025 feet and is projected to fall below 1,000 feet. ${ }^{140}$

Minute 319's shortage-sharing rules have not yet been triggered, but two observations should be made. First, as recently as August 2016, the Bureau of Reclamation's

136. InT'L BOUNDARY \& WATER COMM'N, Minute NO. 319: INTERIM INTERNATIONAL COOPERATIVE MEASURES IN THE COLORADO RIVER BASIN Through 2017 and Extension of Minute 318 CoOperative Measures to AdDREss THE CONTINUED EFFECTS OF THE APRIL 2010 EARTHQUAKE IN THE MEXICALI VALleY, BAJA CALIFORNIA 19 (2012), https://www.ibwc.gov/ Files/Minutes/Minute_319.pdf [hereinafter MinUTE 319].

137. Id. at 3 .

138. See id. at 6-7 (outlining shortage-sharing rules). These shortage-sharing rules have domestic counterparts that preceded them by five years in the Lower Basin. See infra section III.D.2.a.

139. Id. at 6 .

140. Id. at 7 . 
projections for Lake Mead's elevation have suggested a significant probability (upwards of sixty percent) of the shortage-sharing rules being imposed over the next several years. ${ }^{141}$ Second, on July 1, 2016, Lake Mead's actual (not projected) elevation dropped to 1,071.61 feet-roughly threeand-a-half feet below the 1,075 feet shortage tier-marking the lowest storage level since the reservoir's filling in $1937 .{ }^{142}$

Dovetailing with its shortage-sharing rules, Minute 319 also establishes what might be labeled an international water banking scheme, although these terms intentionally were not used in the Minute. ${ }^{143}$ It affords Mexico flexibility in utilizing treaty flows, including enabling Mexico to bolster Lake Mead's storage to avoid the shortage tiers. Minute 319's general approach is to allow Mexico to defer treaty deliveries in order to store the unused water in Lake Mead. If these deferred deliveries stem from Mexico's inability to use the stored water due to infrastructure repairs from a 2010 earthquake in Mexicali Valley, the water is treated as "water deferred" (colloquially, "earthquake water"). ${ }^{144}$ Alternatively, if the deferred deliveries are attributable to Mexico's relying on water yielded from conservation projects (e.g., canal lining) or augmentation projects (e.g., desalination plants), the stored water is considered "Intentionally Created Mexican Allocation" (ICMA). ${ }^{145}$ Notably, Minute 319 imposes limits on (1) Mexico's annual and cumulative creation of ICMA and water

141. U.S. Bureau of Reclamation, The Colorado River System: PROJECTED FUTURE CONDITIONS 2016-2020, at 7 (2016), http://www.usbr.gov/lc/ region/g4000/crss-5year.pdf [https://perma.cc/6GF7-EYE2] [hereinafter SHORTAGE PROJECTIONS].

142. Henry Brean, Lake Mead Still Shrinking, but Lower Consumption Offers Glimmer of Hope, LAS VEGAS REVIEW-JOURNAL, Aug. 6, 2016, http://www.reviewjournal.com/news/las-vegas/lake-mead-still-shrinking-lowerconsumption-offers-glimmer-hope [https://perma.cc/S3F7-4WTD].

143. Spener Interview, supra note 135.

144. See MinUTE 319, supra note 136, at 4 (outlining water deferred program). Mexico can convert water deferred to ICMA. Id. at 8.

145. See id. at 7-10 (outlining ICMA program). Both aspects of this scheme trace to Minute 319's predecessors, Minute 317 and 318. Minute 318 allowed treaty delivery deferrals of up to 260,000 acre-feet annually from 2010 to 2013. Id. at 2-3. Minute 317 likewise contemplated Mexico possibly using U.S. infrastructure to store water. INT'L BOUNDARY \& WATER COMM'N, MinUTE No. 317: CONCEPTUAL FRAMEWORK FOR U.S.-MEXiCO Discussions ON COLORADO RIVER COOPERATIVE ACTIONS 2-3 (2010), http://www.ibwc.gov/Files/Minutes/ Minute_317.pdf [https://perma.cc/4TWT-4QJ4]. The ICMA program also has roots in an Intentionally Created Surplus program implemented domestically in the Lower Basin. See infra section III.D.2.b. 
deferred, 146 and (2) annual amounts of ICMA and water deferred delivered to Mexico, as well as the circumstances in which such deliveries can be made. ${ }^{147}$

Looking at Minute 319 in action, Mexico has yet to utilize the ICMA program to store water in Lake Mead since the Minute's adoption in $2012,{ }^{148}$ but it has relied fairly consistently on the water deferred program. Mexico's deferred delivery account balance was 230,528 acre-feet as of the Bureau of Reclamation's most recent water accounting report in 2015,149 and Mexico had stored 366,134 acre-feet of earthquake water during the preceding four years. ${ }^{150}$

Precisely what lies beyond the interim period's close on December 31, 2017, is unfolding at the time of this writing, but Minute 319 expressly contemplates a "potential comprehensive Minute" extending or replacing its "substantive provisions... through no later than December 31, 2026." 151 At the Colorado River Water Users Association's 2014 annual conference, U.S. and Mexican officials publicly expressed interest in a successor agreement, and dialogue regarding this "Minute $32 \mathrm{x}$ " is ongoing. ${ }^{152}$ As for its content, the binational shortage-sharing

146. MinUTE 319, supra note 136, at 8, 10.

147. Id.

148. Spener Interview, supra note 135.

149. U.S. Bureau of ReClamation, COlorado River ACCOUNTING AND WATER Use REPORT: ARIZONA, CALIFORNIA, AND NEVADA 28 tbl.9 (2015), http://www.usbr.gov/lc/region/g4000/4200Rpts/DecreeRpt/2015/2015.pdf [https://perma.cc/5C98-NJT9] [hereinafter 2015 ACCOUNTING].

150. Id.; U.S. BUREAU OF REClaMATION, COLORADO RIVER ACCOUNTING AND WATER USE REPORT: ARIZONA, CALIFORNIA, AND NEVADA 28 tbl.9 (2014), http://www.usbr.gov/lc/region/g4000/4200Rpts/DecreeRpt/2014/2014.pdf [https://perma.cc/8JEC-RS33] [hereinafter 2014 ACCOUNTING]; U.S. BUREAU OF REClAMATION, COLORADO RIVER ACCOUNTING AND WATER UsE REPORT: ARIZONA, CALIFORNIA, AND NEVADA 24 (2013), http://www.usbr.gov/lc/region/g4000/ 4200Rpts/DecreeRpt/2013/2013.pdf [https://perma.cc/6TLL-8WXJ] [hereinafter 2013 ACCOUNTING]; U.S. BUREAU OF REClamation, COlorado River ACCOUNTING AND WATER UsE Report: ARIZONA, CALIFornia, AND NEVADA 23 (2012), http://www.usbr.gov/lc/region/g4000/4200Rpts/DecreeRpt/2012/2012.pdf [https://perma.cc/F26Y-WER8] [hereinafter 2012 ACCOUNTING]; U.S. BUREAU OF RECLAMATION, COLORADO RIVER ACCOUNTING AND WATER USE REPORT: ARIZONA, CALIFORNIA, AND NEVADA 23 (2011), http://www.usbr.gov/lc/region/g4000/ 4200Rpts/DecreeRpt/2011/2011.pdf [https://perma.cc/43WN-B9KX] [hereinafter 2011 ACCOUNTING].

151. MiNUTE 319, supra note 136, at 3.

152. Spener Interview, supra note 135; Sally Spener, U.S. Sec'y, Int'l Boundary and Water Comm'n, Minute 319 and Beyond: U.S.-Mexico Colorado River Agreements 23-29 (Mar. 9, 2016), http:/www.ibwc.state.gov/Files/ CF_CR_Colo_Agreements_030916.pdf [https://perma.cc/D28W-E8R4]. 
and water storage programs foreseeably will continue in some form, as much interest remains in avoiding (or postponing) shortage-based treaty delivery reductions, and enjoying clarity and certainty regarding shortage administration. ${ }^{153}$ Taken together, these programs constitute a novel approach to the international apportionment, and the shortage-sharing rules are particularly thought-provoking as a means for coping with Article 10(b)'s arguably debilitating ambiguities. Similar patterns can be discerned in the Colorado River Compact's evolution.

\section{B. Colorado River Compact}

We now come to the "constitution," "cornerstone," and "foundation" of the Law of the River. ${ }^{154}$ "The Colorado Compact was not found on a tablet written on Mount Sinai," David Brower once remarked, 155 but in many ways perception appears to belie this truth. The Compact establishes an apportionment for the portion of the Colorado River System within the United States. It has neither been amended by Congress, nor interpreted by the Supreme Court in an express, dispositive manner, ${ }^{156}$ since taking effect in 1929. Perhaps the closest approximation of the latter traces to Meyers's clerkship with Special Master Simon Rifkind, whose Arizona $v$. California report contains rich dicta on the Compact's 6.

153. Spener Interview, supra note 135; UCRC 2015 REPORT, supra note 50, at

154. Robert W. Adler, Revisiting the Colorado River Compact: Time for a Change?, 28 J. LAND RESOURCES \& ENVTL. L. 19, 21 (2008) (constitution); U.S. Bureau of Reclamation, The Law of the River, http://www.usbr.gov/ lc/region/g1000/lawofrvr.html (last updated Mar. 2008) [https://perma.cc/6TG2N3XR] (cornerstone); James S. Lochhead, An Upper Basin Perspective on California's Claims to Water from the Colorado River Part I: The Law of the River, 4 U. DENV. WATER L. REV. 290, 292 (2001) (foundation).

155. MCPHEE, supra note 47, at 241.

156. The Supreme Court disclaimed Compact interpretation in the principal case of Arizona v. California. See, e.g., Arizona v. California, 547 U.S. 150, 166 (2006) (stating the decree shall not affect "[a]ny issue of interpretation of the Colorado River Compact") [hereinafter Decree]. The Court's decision nonetheless holds significant implications for the Compact's apportionment. See generally Jason A. Robison \& Larry J. MacDonnell, Arizona v. California \& the Colorado River Compact: Fifty Years Ago, Fifty Years Ahead, 4 ARIZ. J. ENVTL. L. \& POL'Y 130 (2014) (examining Arizona v. California's historical treatment of, and contemporary implications for, the Compact). 
meaning. ${ }^{157}$ Yet the Compact's apportionment actually has evolved in recent years through the Colorado River Interim Guidelines for Lower Basin Shortages and Coordinated Operations for Lake Powell and Lake Mead (Interim Guidelines). While leaving intact the Compact's framing provisions, the guidelines implement the apportionment for an interim period to avoid deep-rooted conflicts among the Basin States over textual interpretations. This section begins with a survey of the apportionment, then turns to ambiguities in the "constitution," and ultimately outlines how the Interim Guidelines and a Basin States' Agreement have emerged to implement the Compact, and to avoid litigation over it, up to December 31, 2025. ${ }^{158}$

\section{Domestic Basinwide Apportionment}

Aspiring "to provide for the equitable division and apportionment of the use of the waters of the Colorado System," 159 the Compact divides the Colorado River Basin into the two sub-basins identified earlier, an "Upper Basin" and "Lower Basin," authorizing each sub-basin to consumptively use a portion of Colorado River System water. ${ }^{160}$ Structuring the "two-basin" framework are operative terms that begin with "Colorado River System": "that portion of the Colorado River and its tributaries within the United States of America."161 This term delineates the water resources subject to the Compact. As for the entities authorized to consumptively use system water, the "Upper Basin" and "Lower Basin," these

157. Simon H. Rifkind, Special Master, Report, Dec. 5, 1960, Arizona v. California, 373 U.S. 546 (1963) 1960 Term (U.S.), at 138-51 [hereinafter Rifkind Report]; see also Meyers, supra note 14, at 14-15 (describing report as perhaps "most authoritative commentary" on Compact).

158. U.S. DEP'T OF THE INTERIOR, RECORD OF DECISION, COLORADO RIVER INTERIM GUIDELINES FOR LOWER BASIN SHORTAGES AND COORDINATED OPERATIONS FOR LAKE POWELL AND LAKE MEAD (2007), http://www.usbr.gov/lc/region/programs/strategies/RecordofDecision.pdf [https://perma.cc/8KFX-34Y4] [hereinafter INTERIM GUIDELINES ROD]; Agreement Concerning Colorado River Management and Operations (Apr. 23, 2007), http://www.usbr.gov/lc/region/programs/strategies/DEIScomments/State/ BasinStates.pdf [https://perma.cc/8EUB-V2S4] [hereinafter Basin States' Agreement]. This agreement appears as attachment A of the linked document.

159. Compact, supra note 18, § 37-61-101, art. I.

160. See Meyers, supra note 14, at 12-18 (surveying Compact's provisions).

161. Compact, supra note $18, \S 37-61-101$, art. II(a). 
terms refer to geographic areas (again, sub-basins) encompassing drainage areas within and export areas outside the Colorado River Basin's hydrological boundaries above and below, respectively, Lee Ferry. ${ }^{162}$ Closely related to these definitions demarcating the sub-basins' boundaries are the terms "States of the Upper Division" (Colorado, New Mexico, Utah, and Wyoming), 163 and "States of the Lower Division" (Arizona, California, and Nevada). ${ }^{164}$ These political groupings are critical in relation to flow obligations imposed by the Compact.

Article III puts the foregoing terms into motion. Five paragraphs within it constitute the framing provisions of the Compact's apportionment: Articles III(a) through (e).

Articles III(a) and (b) establish apportionments for the Upper and Lower Basins. Article III(a) apportions "from the Colorado River System in perpetuity to the Upper Basin and to the Lower Basin[,] respectively[,] the exclusive beneficial consumptive use of 7,500,000 acre-feet of water per annum."165 Article III(b), in turn, augments the Lower Basin's Article III(a) apportionment, stating: "[i]n addition to the apportionment in paragraph (a)[,] the Lower Basin is hereby given the right to increase its beneficial consumptive use of such waters by one million acre-feet per annum."166 Taken together, these two paragraphs thus authorize the Upper and Lower Basins to engage in "beneficial consumptive use" of 7.5 and 8.5 maf of water per year, respectively, from the Colorado River System-16.0 maf in total.

Articles III(c) and (d), in turn, focus on flow obligationsthe former international, the latter domestic-and appear adjacent to a water-hoarding prohibition in Article III(e). Article III(c) is concerned with flow obligations tethered to Mexico's 1.5 maf treaty apportionment. ${ }^{167}$ It provides that treaty water "shall be supplied first from the waters which are surplus over and above the aggregate of the quantities specified in [Articles III(a) and (b)]."168 "[I]f such surplus shall

\footnotetext{
162. Id. § 37-61-101, arts. II(f)-(g).

163. Id. § 37-61-101, art. II(c).

164. Id. § 37-61-101, art. II(d).

165. Id. § 37-61-101, art. III(a).

166. Id. § 37-61-101, art. III(b).

167. Treaty, supra note 19, at art. 10(a).

168. Compact, supra note 18, § 37-61-101, art. III(c).
} 
prove insufficient for this purpose," Article III(c) states that "the burden of such deficiency shall be equally borne by the Upper Basin and the Lower Basin, and whenever necessary the States of the Upper Division shall deliver at Lee Ferry water to supply one-half of the deficiency."169 As Meyers highlighted fifty years ago, bitter disputes attend this text. ${ }^{170}$ As for Article III(d), its flow obligation falls solely on the Upper Division states, providing that these states "will not cause the flow of the river at Lee Ferry to be depleted below an aggregate of $75,000,000$ acre-feet for any period of ten consecutive years reckoned in continuing progressive series." 171 Following these provisions is Article III(e) and its water hoarding prohibition: "The States of the Upper Division shall not withhold water, and the States of the Lower Division shall not require the delivery of water, which cannot reasonably be applied to domestic and agricultural uses."172

While the foregoing paragraphs make up the foundation of the Compact's apportionment, two related provisions should be mentioned. Article VII-the so-called "wild Indian article"173_ states tersely: "Nothing in this compact shall be construed as affecting the obligations of the United States of America to Indian tribes." 174 Article VIII further provides in relevant part: "Present perfected rights to the beneficial use of waters of the Colorado River System are unimpaired by this compact." 175 The Compact contemplates that water consumptively used by holders of present perfected rights falls within the Article III(a)

169. Id.

170. Meyers, supra note 14 , at 16-17, 24-25.

171. Compact, supra note 18, § 37-61-101, art. III(d). The term "flow obligation" is used as a shorthand for Article III(d)'s text. Others prefer "nondepletion requirement" or "non-depletion obligation" for reasons generally pertaining to the Compact's non-impairment of present perfected rights and the basin's uncertain future hydrology. See, e.g., Eric Kuhn, Risk Management Strategies for the Upper Colorado River Basin 13 (Jan. 2, 2012), http://103.46.239.148:8081/CRD.com/images/PDF/risk_mgmnt/kuhn_on_risk_mg_ strategies_of_the_ucrb.pdf [https://perma.cc/DN7S-AYW6] (non-depletion requirement).

172. Compact, supra note 18, § 37-61-101, art. III(e).

173. See NorRis Hundley, JR., WATER AND the West: The Colorado River COMPACT AND The Politics OF WATER IN THE AMERICAN West 211-12 (2d ed. 2009) (describing unflattering dialogue surrounding Article VII at Compact negotiations).

174. Compact, supra note 18, § 37-61-101, art. VII; see also Upper Basin Compact, supra note 20, at art. XIX(a) (counterpart provision).

175. Compact, supra note $18, \S 37-61-101$, art. VIII. 
apportionments and must be counted against the sub-basin in which the use occurs. ${ }^{176}$ The ambiguous meaning of "present perfected rights," however, serves as fodder for the discussion below.

\section{Ambiguities in the Law of the River's Constitution}

A host of structural issues and textual ambiguities afflict the preceding provisions. Most fundamental in the structural realm is the monumental fact that they were founded on inordinately high flow estimates. As just one illustration, comments from Arthur Powell Davis, U.S. Reclamation Service Commissioner, to Arizona Congressman Carl Hayden in January 1923 estimated average annual natural flows at Lee Ferry of 18.1 maf based on the 1903 to 1920 period. ${ }^{177}$ A stream gauge actually was not installed until 1921 at Lees Ferry-a gauging station two miles upstream of the Compact dividing point of "Lee Ferry"178_and the Upper Colorado River Commission estimates from 1922 to 2015 natural flows at Lee Ferry averaged 14.1 maf annually. ${ }^{179}$ As noted earlier, the Bureau of Reclamation similarly has reported these flows averaging approximately 14.8 maf per year from 1906 to 2015. ${ }^{180}$ At the end of the day, as Norris Hundley, Jr. aptly summed it, "[t]he consequences of the compact remain with us."181 This sentiment applies equally to the Compact's text. "[T]he 1922 compact solves some problems but leaves others unsolved and, in fact, by its language creates problems that have become the subject of continuing controversy." 182 Meyers's assessment is durable five decades later. Much has been written about the textual ambiguities and derivative conflicts, and the material below sheds modest light in this realm. Its

176. Id. § 37-61-101, arts. III(a), VIII.

177. HOOVER DAM DOCUMENTS, supra note 109, at A48; see also CRGI REPORT, supra note 38 , at 70 (noting additional examples).

178. See U.S. Bureau OF ReClamation, The Colorado River Documents 2008 at $2-9$ to -10 (2010) (identifying gauging station's location vis-à-vis Lee Ferry).

179. UCRC 2015 REPORT, supra note 50, at 22.

180. Open Data, supra note 9. See also UCRC 2015 REPORT, supra note 50, at 25 tbl.3 (indicating natural flows at Lee Ferry averaged 14.6 maf annually from 1896 to 2015$)$.

181. HUNDLEY, supra note 173 , at 352 .

182. Meyers, supra note 14, at 18. 
paramount goal is to clarify exactly how the Interim Guidelines finesse particular ambiguities that have proven divisive since the historic drought's onset in 2000.

Beginning with Article III(a) and (b) and Article VIII, key text bearing on the Upper and Lower Basins' apportionments is unclear and/or contested. A handful of examples suffice to illustrate. They generally concern the terms "beneficial consumptive use" and "present perfected rights" as well as the hydrological scope of the "Colorado River System."

Consider initially how "the compact does not define the term 'beneficial consumptive use' as employed in apportioning water between the basins," 183 and how "the two basins disagree over the meaning of this term." 184 The critical difference concerns whether reservoir evaporation-substantial on a basinwide scale ${ }^{185}$ _constitutes "beneficial consumptive use." The Upper Basin Compact takes this approach, while the Arizona v. California decree does not. ${ }^{186}$ Again, the Compact's text is elusive.

In a similar vein, the Compact lacks a definition of "present perfected rights" as it appears in Article VIII's reference to water rights "unimpaired by this compact." 187 As with the "beneficial consumptive use" definitional vacuum, the Upper Division and Lower Division states diverge. The split is over the date governing whether a water right qualifies as a "present perfected right": November 24, 1922 (Compact's signing date) per the Upper Basin Compact or June 25, 1929 (Compact's effective date) per the Arizona $v$. California decree. ${ }^{188}$

Yet another ambiguity relates to the Compact's hydrological scope-namely, whether Article III(a) and (b) apply to the use of groundwater hydrologically connected to surface water (tributary groundwater) within the Colorado

183. Id. at $18-19$.

184. Id. at 15 .

185. See TECHNICAL REPORT C, supra note 35, at C-48 (noting average annual reservoir evaporation of 2.0 maf between 1971 and 2010).

186. Compare Upper Basin Compact, supra note 20, at arts. V, VI (addressing inflow-outflow measurement method and treatment of reservoir evaporation), with Decree, supra note 156, at art. I(A) (defining "consumptive use" as "diversions from the stream less such return flow thereto").

187. Compact, supra note 18, § 37-61-101, art. VIII.

188. Compare Upper Basin Compact, supra note 20, at art. IV(c) (signing date), with Decree, supra note 156, at art. I(H) (effective date). 
River System. "The compact contains no express provision regarding groundwater," as explained by Meyers, although he also highlighted how the Supreme Court had subjected tributary groundwater use to the Arizona $v$. California decree "with no more textual authority than there is in the compact."189

Finally, notwithstanding its explicit definition of "Colorado River System,"190 an epic dispute also implicating the Compact's hydrological scope concerns whether Article III(a) and (b) encompass and thus require accounting for water use along Lower Basin tributaries-particularly, the Gila River. ${ }^{191}$ The State of Arizona unsuccessfully argued to the contrary in Arizona v. California-with Special Master Rifkind rejecting this argument per the Compact's "plain words"-but this dicta is not dispositive. ${ }^{192}$

Turning to Article III(c) and (d), ambiguities of equal or arguably greater importance stem from the flow obligations imposed by these provisions. For reasons that will become clear, my focus is on the former. As Meyers described, "[f]rom the time of the signing of the Mexican treaty, if not long before, there have been conflicting interpretations of article III(c)."193

At the outset, Article III(c)'s flow obligation implicates the foregoing issue of whether the Compact's apportionment encompasses the Gila River and other Lower Basin tributaries. In this context, the query is whether tributary water must be accounted for when assessing whether "surplus" or "deficiency" conditions exist within the meaning of Article III(c). 194

A closely connected second ambiguity involves what water

189. Meyers, supra note 14 , at 26 .

190. See Compact, supra note 18, at art. II(a) (defining "Colorado River System" as "that portion of the Colorado River and its tributaries within the United States of America").

191. See, e.g., David H. Getches, Competing Demands for the Colorado River, 56 U. COLO. L. REV. 413, 424-25 (1985).

192. Rifkind Report, supra note 157, at 142.

193. Meyers, supra note 14 , at 25. For an insightful discussion about the contested nature of Article III(d)'s flow obligation, see COLORADO RIVER GOVERNANCE INITIATIVE, GETCHES-WILKINSON CENTER FOR NATURAL Resources, Energy and the Environment, Does the UpPer Basin Have a DELIVERY OBLIGATION OR AN OBLIGATION Not TO DEPLETE THE FlOW OF THE COLORADO RIVER AT LEE FERRY? (2012), http://scholar.law.colorado.edu/ cgi/viewcontent.cgi?article=1006\&context=books_reports_studies [https://perma.cc/XB37-5QW8].

194. See, e.g., Getches, supra note 191, at 424-25. 
constitutes "surplus" for purposes of the provision. On one side, the Upper Division states have contended surplus consists of (1) water being used in the Lower Basin in excess of the 8.5 maf apportionment in Article III(a) and (b), or perhaps (2) water above and beyond the 8.5 maf apportionment plus the lesser of the Upper Basin's consumptive use or its 7.5 maf apportionment in Article III(a). ${ }^{195}$ On the other side, the Lower Division states have countered that surplus consists of water within the Colorado River System in a given year exceeding the aggregate 16.0 maf apportioned by Article III(a) and (b). ${ }^{196}$ This divergence directly affects Article III(c)'s implementation.

A third ambiguity relates to evaporation and other losses associated with treaty water-specifically, the Upper Division states' purported mandatory coverage of half of these losses below Lee Ferry. ${ }^{197}$ Does Article III(c) require such a carriage water contribution? Predictably, the Lower Division states have said "yes," 198 while the Upper Division states have said "no."199

Finally, a further divisive ambiguity concerns Article III(c)'s implementation when surplus exists. If "surplus" indeed consists of water within the Colorado River System in a given year beyond the aggregate 16.0 maf apportioned by Article III(a) and (b), does its existence alleviate the Upper Division states' obligation to contribute treaty flows? At least one Lower Division state, Arizona, has argued otherwise: "[U]nder Article III(c), the Compact requires the release of more than one-half of the Mexican Treaty obligation from Lake Powell in surplus years." 200 An intertwined matter is whether Article III(c)'s implementation in the event of surplus requires locating precisely where within the Colorado River System the surplus exists, such that it can be sourced as the first supply for treaty

195. See Lochhead, supra note 154, at 320 (first argument); Kuhn, supra note 171 , at 34 (second argument).

196. W. Patrick Schiffer et al., From a Colorado River Compact Challenge to the Next Era of Cooperation Among the Seven Basin States, 49 ARIZ. L. REV. 217, 222, 226 (2007).

197. Meyers, supra note 14, at 17.

198. See, e.g., Schiffer et al., supra note 196, at 225.

199. See, e.g., John U. Carlson \& Alan E. Boles, Jr., Contrary Views of the Law of the Colorado River: An Examination of Rivalries Between the Upper and Lower Basins, 32 Rocky MTN. Min. L. INST. 21, § 21.05[2][c] (1986).

200. Schiffer et al., supra note 196 , at 226 . 
deliveries. ${ }^{201}$

Volumes more could be said about the Compact ambiguities, but this gloss hopefully conveys the basic point that the Compact's meaning is contested. "No doubt it would be ungrateful to remark that perhaps speedy agreement was bought at the price of clarity of meaning," wrote Meyers in The Colorado River, "but the fact remains that many observers are uncertain in their understanding of the document."202 To this insight Meyers added regarding the "beneficial consumptive use" and Article III(c) ambiguities, "[t]hey are all disputes of which the compact negotiators were aware but failed to resolve because of imperfections of language and perhaps because of an underlying lack of agreement." 203 The ambiguities' persistence since Meyers's scholarship itself is a noteworthy characteristic of the allocation framework's evolution over the past fifty years. Even more important for this discussion, however, is the historic drought's accentuation of tensions over the ambiguities during the past decade, and the Interim Guidelines' emergence as a mechanism for temporarily navigating these tensions.

\section{Pragmatism Redux: Interim Guidelines \& Compact Implementation}

The Compact ambiguities are relevant systemically within the Law of the River. This observation brings us back to the Colorado River Basin Project Act. Section 602(a) of the Act directs the Secretary of the Interior to establish Long-Range Operating Criteria for reservoirs constructed under the Boulder Canyon Project Act (Lake Mead) and Colorado River Storage Project Act (Lake Powell and its counterparts). ${ }^{204}$ Initially adopted in 1970, these criteria govern storage in Upper Basin reservoirs and releases from Lake Powell. ${ }^{205}$ Section 602(a) sets an order of priority around which the Secretary must frame the criteria. Designated as first and

201. Kuhn, supra note 171 , at 34 n.68.

202. Meyers, supra note 14, at 12.

203. Id. at 18 .

204. Colorado River Basin Project Act $§ 602(a), 43$ U.S.C. $§ 1552(a)$ (2012).

205. U.S. BUREAU OF RECLAMATION, CRITERIA FOR COORDINATED LONGRANGe Operation of Colorado River Reservoirs Pursuant to THE Colorado River Basin Project ACt of SePtember 30, 1968 (June 8, 1970), http://www.usbr.gov/lc/region/pao/pdfiles/opcriter.pdf [https://perma.cc/VCU6ZW5E] [hereinafter LROC]. 
second priorities, respectively, are Lake Powell releases needed to satisfy the Upper Division states' flow obligations to Mexico and the Lower Division states under Articles III(c) and (d) of the Compact. ${ }^{206}$ Section 602(a) further designates as a third priority storage of water not required for such releases to the extent that the Secretary finds it "reasonably necessary to assure deliveries" for the first and second priorities. ${ }^{207}$ In this precise way, Article III(c)'s ambiguities interface directly with section 602(a) and the Long-Range Operating Criteria, thereby prompting conflicts that trace back decades regarding whether reservoir operations comport with the Compact. An especially heated subject has been the criteria's specification of a minimum objective release of 8.23 maf per year from Lake Powell. ${ }^{208}$ Inclusion of Article III(c) treaty flows within this 8.23 maf release has been the sticking point. Simply put, "based on their view of the Mexican Treaty obligation, the [s]tates of the Upper Division believe that 8.23 maf is not justified,"209 while the Lower Division states have taken the opposite stance. ${ }^{210}$

Signed by Secretary of the Interior Dirk Kempthorne on December 13, 2007, the Interim Guidelines "implement" the Long-Range Operating Criteria up to December 31, 2025. ${ }^{211}$ These guidelines and an accompanying Basin States' Agreement prescribe the existing approach to the historic conflicts over Article III(c) and concomitantly section 602(a) of the Colorado River Basin Project Act. Numerous sources shed light on the context surrounding the guidelines' formation. ${ }^{212}$ It suffices to say, however, that the historic drought's drastic impact on reservoir storage during the first several years

206. Colorado River Basin Project Act $\S 602(a), 43$ U.S.C. $\S 1552(a)(1)-(2)$ (2012).

207. Id. $\S 602(\mathrm{a})(3)$.

208. LROC, supra note 205 , at art. II(2).

209. Kuhn, supra note 171 , at 29 . The 8.23 maf release is commonly described as encompassing 750,000 acre-feet of Article III(c) treaty flows. See, e.g., Schiffer et al., supra note 196, at 225 . This accounting, however, is not uniformly agreed upon. Telephone Interview with John Shields, Agric. Eng'r, U.S. Bureau of Reclamation, Lower Colo. Reg'l Office, former Interstate Streams Eng'r, Wyo. State Eng'r's Office (1984-2014) (Aug. 4, 2015) [hereinafter Shields Interview I].

210. See, e.g., Schiffer et al., supra note 196, at 225.

211. INTERIM GUIDELINES ROD, supra note 158 , at $22,57$.

212. See generally Douglas L. Grant, Collaborative Solutions to Colorado River Water Shortages: The Basin States' Proposal and Beyond, 8 NeV. L.J. 964 (2008) (illuminating guidelines' formation); Schiffer et al., supra note 196 (same). 
brought the Article III(c) and section 602(a) conflicts to a boil, ${ }^{213}$ and that these conflicts gradually simmered beginning in 2005 with the Basin States' engagement in a National Environmental Policy Act process commenced by Secretary of the Interior Gale Norton. Shortly after engaging in this process, the states realized they would need to set aside their differences over Article III(c) and section 602(a) to prepare a proposal that might shape the guidelines' makeup under a timeline set by the Secretary. ${ }^{214}$

Relevant to the Compact's apportionment, the specific manner in which the Interim Guidelines implement the LongRange Operating Criteria-and thus section 602(a) of the Colorado River Basin Project Act and ultimately Articles III(c) and (d) - is through a coordinated operating regime for Lake Powell and Lake Mead. ${ }^{215}$ This regime establishes a four-tier schedule for annual Lake Powell releases, with the release amounts fluctuating based upon the relative elevations of Lake Powell and Lake Mead. More specifically, Lake Powell's projected elevation as of January 1 each year determines the applicable operational tier-“equalization tier," "upper elevation balancing tier," "mid-elevation release tier," or "lower elevation balancing tier"-and the relationship between this projected elevation and that of Lake Mead dictates the amount of water released from Lake Powell within a range prescribed for the particular tier.216 For example, if Lake Powell's projected elevation lies between 3,525 and 3,575 feet, the applicable tier is the mid-elevation release tier, and the annual release from Lake Powell within this tier will be either (1) 7.48 maf if Lake Mead's projected elevation is at or above 1,025 feet, or (2) 8.23 maf if Lake Mead's projected elevation is below

213. See INTERIM GUIDELINES ROD, supra note 158, at 11 (describing risk of basinwide litigation); Letter from the States of Colo., N.M., Utah and Wyo. Governor's Representatives on Colo. River Operations to Lower Div. State Representatives (Oct. 7, 2004), http://www.usbr.gov/uc/rm/amp/amwg/ mtgs/04oct25/Attach_12.pdf [https://perma.cc/5DW4-7EZ4] (describing how declining reservoir levels have raised fundamental issues related to Compact and other parts of Law of the River-including "fundamental issue" of "whether a deficiency exists under Article III(c)"-and expressing position that "because no such deficiency has been shown to exist, the Upper Basin has no obligation in this regard").

214. Grant, supra note 212, at 979; Shields Interview I, supra note 209.

215. INTERIM GUIDELINES ROD, supra note 158, at 49-53.

216. Id. at $50-53$. 
1,025 feet. ${ }^{217}$ Notably, annual Lake Powell releases may be as low as 7.0 maf under this regime. ${ }^{218}$

In adopting the coordinated operating regime, the Interim Guidelines dealt carefully with the Article III(c) and section 602(a) conflicts, which also underpinned a complementary Basin States' Agreement already noted. While recognizing that differences exist regarding the Law of the River's interpretation, "including ... Section 602(a) of the Colorado River Basin Project Act," the guidelines reserved such disputes from formal determination by the Secretary of the Interior. ${ }^{219}$ In lieu of a formal determination, "the Secretary will apply the operational criteria in [the] Guidelines," with corresponding disclaimers that "[a]ctual operations under [the] Guidelines shall not represent interpretations of existing law by the Secretary," and that Lake Powell releases pursuant to the guidelines "shall not prejudice the position or interests of either the Upper or Lower Division states . . . with respect to required storage or deliveries of water" under the Law of the River. ${ }^{220}$ To a similar effect, the guidelines' adoption activated a legal agreement in which the Basin States "agreed to mandatory consultation provisions to address future controversies on the Colorado River through consultation and negotiation ... before resorting to litigation." 221 The agreement expressed a "desire to avoid judicial or administrative proceedings"-which were not considered "preferred alternatives to the resolution of claims or controversies concerning the law of the river"222-and prohibited parties from initiating such proceedings over inter alia Article III(c) or section 602(a) prior to engaging in mandatory consultation. ${ }^{223}$

Eyeing the future, synced review and expiration timelines apply to the Interim Guidelines and Basin States' Agreement over the next ten years. By no later than December 31, 2020, the Secretary of the Interior will initiate "a formal review for purposes of evaluating the effectiveness" of the Interim Guidelines, consulting with the Basin States in this process. ${ }^{224}$

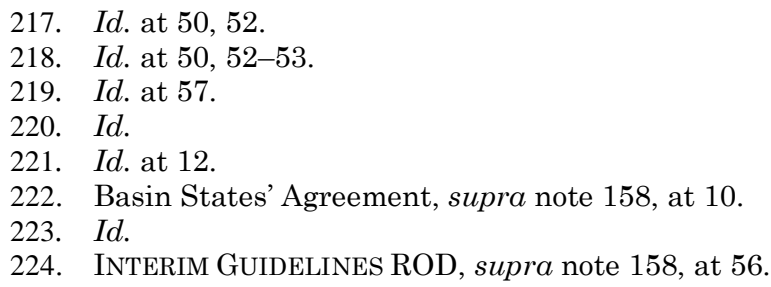


The Basin States' Agreement similarly calls for consultation by this date regarding whether the agreement should be extended, modified, or terminated.225 Both documents are commonly hinged to the Interim Guidelines' general expiration on December 31, 2025. ${ }^{226}$

It is in the nuanced fashion detailed above that the Compact's Article III(c) and (d) flow obligations are being implemented fifty years after The Colorado River. Notwithstanding the persistence of unresolved ambiguities associated with the Upper Basin and Lower Basin apportionments as a stand-alone aspect of the Compact's history, a truly intricate legal construct has evolved involving Article III(c) and (d), section 602(a) of the Colorado River Basin Project Act, the Long-Range Operating Criteria, and, at the top of the pile, the Interim Guidelines. Pending no changes stemming from consultation during the interim period, ${ }^{227}$ this construct will continue to coordinate Lake Powell's and Lake Mead's operations until December 31, 2025, with the guidelines' formal review slated to commence five years earlier (though it may begin sooner). ${ }^{228}$ Policymakers engaged in the formal review-and also consultation regarding the Basin States' Agreement-foreseeably will have to revisit, in one form or another, the Article III(c) and section 602(a) ambiguities. ${ }^{229}$ The outcome of this dialogue remains to be seen. As described eloquently after the first round of negotiations (i.e., the Interim Guidelines' formation), "a compact does not mark the final stage of problem-solving, only the beginning," and "[t]his has certainly been true for the Colorado River Compact." 230

225. Basin States' Agreement, supra note 158, at 8.

226. INTERIM GUIDELINES ROD, supra note 158, at 57; Basin States' Agreement, supra note 158, at 13. To be clear, the Basin States' Agreement's mandatory consultation provision states it will "survive for a period of five years following the termination or expiration" of the agreement. Basin States' Agreement, supra note 158, at 10.

227. See INTERIM GUIDELINES ROD, supra note 158, at 55 (calling for initial consultation if Lake Mead's projected January 1 elevation is below 1,025 feet, and additional consultation to discuss "further measures" if elevation appears likely to fall below 1,000 feet).

228. See Kuhn, supra note 171, at 24 (anticipating negotiations will "start much sooner").

229. See id. at 29 (describing debate has been temporarily postponed by Interim Guidelines, but when states resume negotiations "602(a) could resurface as a very contentious issue"); Shields Interview I, supra note 209.

230. Patricia Mulroy, Collaboration and the Colorado River Compact, 8 NEV. L.J. 890, 894 (2008). 


\section{Upper Basin Compact}

Governing Colorado River System water use upstream of Lee Ferry is the second interstate compact subsumed within the Law of the River: the Upper Basin Compact. Its 1948 genesis lies roughly equidistant between the Colorado River Compact's drafting in 1922 and the publication of Meyers's scholarship. A tight, nested relationship exists between the compacts. The Upper Basin Compact outlines an apportionment for the five states with territory in the Upper Basin-primarily Colorado, New Mexico, Utah, and Wyoming, but also Arizona to a limited extent. This scheme is rooted in the 7.5 maf apportionment established for the Upper Basin in Article III(a) of the Compact, yet it is also framed around the flow obligations imposed on the Upper Division states by Article III(c) and (d). Reconciliation of these key provisions in modern times places the Upper Division states in a marginally tighter space than has existed in the past. Avoiding a call on the river rooted in the flow obligations (Compact call), and resulting curtailments under Article IV of the Upper Basin Compact, is and will remain a key priority. It is likewise a priority that overlaps with maintaining Lake Powell's storage and protecting hydropower generation and associated revenues at Glen Canyon Dam. Important administrative matters, too, must be considered in relation to low flows and storage, and thus the prospect of a Compact call and curtailment. These concerns have shaped the evolutionary narrative in this realm, which initially entails exploring the Upper Basin apportionment.

\section{Upper Basin Apportionment}

The Upper Basin Compact is inseverable from its predecessor, the Compact, and in multiple respects the instruments' core provisions track one another. ${ }^{231}$ One shared feature relates to the Upper Basin Compact's first stated purpose: "equitable division and apportionment of the use of the waters of the Colorado River System, the use of which was apportioned in perpetuity to the Upper Basin by the Colorado

231. See Meyers, supra note 14, at 31-37 (surveying Upper Basin Compact's provisions). 
River Compact."232 Dovetailing with this purpose is a successive one further revealing the compacts' nestedness: "to establish the obligations of each State of the Upper Division with respect to the deliveries of water required to be made at Lee Ferry by the Colorado River Compact."233 To a similar effect, the Upper Basin Compact incorporates the Compact's operative terms, including "Colorado River System," "Upper Basin," "Lower Basin," "States of the Upper Division," and "States of the Lower Division." 234 In short, the Upper Basin Compact is designed to be congruent with the Compact, and the instruments commonly focus on effecting equitable apportionments within their overlapping spheres.

Article III of the Upper Basin Compact contains its apportionment, marking another commonality with the Compact in form, though not in substance. Article III initially apportions from the Upper Colorado River System 50,000 acrefeet of consumptive use per year to Arizona.235 After this quantity-based apportionment, Article III establishes percentbased apportionments for the Upper Division states. Colorado, New Mexico, Utah, and Wyoming are entitled to the consumptive use of $51.75 \%, 11.25 \%, 23 \%$, and $14 \%$, respectively, of the "total quantity of consumptive use per annum apportioned in perpetuity to and available for use each year by [the] Upper Basin under the Colorado River Compact" (i.e., after deducting Arizona's 50,000 acre-feet). ${ }^{236}$ Inclusion of the phrase "available for use" in this text is critical. It reveals the reason for the percent-based apportionments-namely, "uncertainty about how much water will ultimately be available under the Colorado River Compact"237 after the Upper Division states have satisfied their Article III(c) and (d) flow obligations. Thus, "the allocation of each Upper Division state is uncertain and variable."238 Regarding how "consumptive use" is measured for the apportionment, the compact employs an "inflow-outflow method"239 that charges reservoir evaporation against the states' apportionments as

232. Upper Basin Compact, supra note 20, at art. I.

233. Id.

234. Id. at arts. II(a), (c), (d), (f), (g).

235. Id. at art. III(a)(1).

236. Id. at art. III(a)(2).

237. Lochhead, supra note 154 , at 319 .

238. Id.

239. Upper Basin Compact, supra note 20, at art. VI. 
noted earlier. ${ }^{240}$

Closely linked with the foregoing apportionment, the Upper Basin Compact in Article IV establishes a system for curtailing the Upper Division states' consumptive use to ensure "the flow at Lee Ferry shall not be depleted below that required by Article III of the Colorado River Compact."241 As observed by Meyers, Article IV is "extremely important because it provides the formula and mechanism for curtailing consumption if a drought should make it impossible for the [Upper Division states] to meet [the] Lee Ferry delivery obligation and still maintain existing uses." 242

Overall, Article IV puts into place a two-tier curtailment system for the Upper Division states. It calls for initial curtailments accounting for any state's exceedance of its apportionment over the preceding ten years, ${ }^{243}$ followed by subsequent curtailments generally imposed on a pro-rata basis across the states as a group. ${ }^{244}$ Notably, the provision governing the latter curtailments excludes from the pro-rata calculation present perfected rights-that is, "uses of water under rights perfected prior to November 24, 1922" (again, the Compact's signing date). ${ }^{245}$ As Meyers explained, this exclusion "was probably thought to be necessary because of article VIII of the 1922 compact, which declared 'present perfected rights' to be unimpaired by the agreement."246 Article IV's administration rests with the Upper Colorado River Commission. In line with the two-tier system, "the extent of curtailment by each State ... shall be in such quantities and at such times as shall be determined by the Commission." 247 Additional details regarding Article IV appear below to further elucidate the contemporary relevance of potential curtailments to the Upper Division states, individually and collectively,

240. Id. at art. V(a)-(b); see also Meyers, supra note 14, at 34 (describing accounting of reservoir evaporation as "substantial advance" over Compact and Arizona $v$. California decree).

241. Upper Basin Compact, supra note 20, at art. IV.

242. Meyers, supra note 14, at 32.

243. Upper Basin Compact, supra note 20, at art. IV(b).

244. Id. at art. IV(c).

245. Id.

246. Meyers, supra note 14, at 33 n.134.

247. Upper Basin Compact, supra note 20, at art. IV. The Commission, however, does not possess authority to enforce curtailment orders. Meyers, supra note 14 , at 34 . 
under this keystone provision.

\section{Compact Calls \& Curtailments}

"How to build a future on the right to leftovers?"248 Meyers and his co-author David Getches, the late Dean of the University of Colorado Law School, posed this "ultimate question" for the Upper Basin twenty years after The Colorado River. ${ }^{249}$ They are certainly not the only Law of the River students (experts, truly) to have raised it. ${ }^{250}$ The discussion above hopefully makes sense of why that is. Notwithstanding the diverse values supported by non-consumptive water use within the Upper Basin, the extent of consumptive use the Upper Division states are legally capable of undertaking hinges directly on what remains after the Compact's Article III(c) and (d) flow obligations have been met. The Upper Basin Compact apportions these very leftovers. And demands for them have increased steadily since Meyers's scholarship, from approximately 3.4 maf in 1971 to 3.9 maf in 2014. ${ }^{251}$ The Basin Study projected this pattern will continue for the next halfcentury, with Upper Basin consumptive uses ranging from slightly below 5.0 maf to approximately 6.0 maf by 2060 , excluding reservoir evaporation. ${ }^{252}$ Just as the Compact flow obligations factor into the realism of these projections, so too do climate change's future impacts on Lee Ferry flows. What appears clear retrospectively is that the Upper Division states gradually have moved closer toward the outer bounds of their

248. David H. Getches \& Charles J. Meyers, The River of Controversy: Persistent Issues, in NEW COURSES FOR THE COLORADO RIVER: MAJOR ISSUES FOR The NeXt CEntury 51, 56 (Gary D. Weatherford \& F. Lee Brown eds., 1986).

249. Id.

250. See Lochhead, supra note 154, at 310 (describing one problem for Upper Basin apportionment was "how to handle the 'leftovers' from the Upper Basin supply after it had met its obligation under Article III(d)" of the Compact). Getches's seminal work includes David H. Getches, Colorado River Governance: Sharing Federal Authority as an Incentive to Create a New Institution, 68 U. COLO. L. REV. 573 (1997); Getches, supra note 191.

251. U.S. Bureau of Reclamation, UpPer Colorado River Basin Consumptive Uses AND Losses Report As Revised After PeER RevieW 197119955 tbl.UC-1, 6 tbl.UC-2 (identifying 441,900 acre-feet of mainstem reservoir evaporation and 2.9514 maf of consumptive uses and non-mainstem reservoir evaporation in 1971); 2015 CUL REPORT, supra note 71, at 11 tbl.UC-1, 15 tbl.UC5 (identifying 442,600 acre-feet of mainstem reservoir evaporation and 3.4526 maf of consumptive uses and non-mainstem reservoir evaporation in 2014).

252. TECHNICAL REPORT C, supra note 35, at C-26 fig.C-9. 
apportionments, however vague these edges may be. ${ }^{253}$ It is not a situation comparable in scale and constraint to that of the Lower Division states under the Arizona $v$. California decree. But with a fair amount of variation across the group, the Upper Division states generally are in a marginally tighter space than historically has been the case with regard to the leftovers' bounty. ${ }^{254}$

Conveying the situation upstream of Lee Ferry in slightly more detail, the Upper Division states' consumption of the leftovers has yet to precipitate a Compact call. Reflective of the Article III(d) flow obligation, the Upper Colorado River Commission maintains a progressive decadal total of Lee Ferry flows, and from the historic drought's onset in 2000 to 2015 it ranged from approximately 84.8 to 102.6 maf. ${ }^{255}$ The Commission, therefore, has not been required during this period or any other to administer Article IV curtailments under the Upper Basin Compact. Nonetheless, in assessing the Upper Basin apportionment's evolution, the prospect of a Compact call and curtailment has been a key dynamic that has driven decision-making over the past decade and will continue to do so. Further, intertwined with this dynamic is a premium on maintaining Lake Powell's storage to avoid reductions in Glen Canyon Dam's hydropower generation and associated revenues used to fund projects and programs, including several in the environmental realm. ${ }^{256}$ But avoidance has not been the only game in town. Curtailment administration efforts also have been in play, both within the Upper Division states and to a lesser extent at the interstate level. The material below offers a glimpse of these developments associated with the Upper Basin

253. See U.S. Bureau of Reclamation, Colorado River Water Supply AND DEMAND STUdy, TeChNicAl REPORT C app. C10 Historical CONSUMPTIVE Use AND LOSS DETAIL BY STATE C10-1 to -9 (2012), https://www.usbr.gov/lc/ region/programs/crbstudy/finalreport/Technical\%20Report\%20C\%20-\%20Water\% 20Demand\%20Assessment/TR-C_Appendix10_FINAL.pdf [https://perma.cc/FTD9B6US] (identifying states' historical consumptive uses and losses).

254. See Jason Anthony Robison, Climate Change and Allocation Institutions in the Colorado River Basin, in WeStern WATER POLICY AND PLANNING IN A VARIABLE AND CHANGING Climate 289, 301 tbl.16.1, 302 tbl.16.2 (2016) (analyzing states' water budgets under Upper Basin Compact).

255. See UCRC 2015 REPORT, supra note 50, at 26 tbl.4.

256. See, e.g., Frequently Asked Questions, GLEN CANYON DAM ADAPTIVE MANAGEMENT PROGRAM, http://www.gcdamp.gov/faq.html (last visited Aug, 11, 2016) [https://perma.cc/ DL4G-9W3C] (discussing Glen Canyon Dam hydropower generation and revenues for salinity control and environmental programs). 
apportionment—and, at bottom, the leftovers.

\section{a. Administration: Article IV, PPRs \& Measurement Methods}

How exactly does Article IV of the Upper Basin Compact work? Because no Compact call has necessitated curtailments, this provision has yet to be implemented, including being interpreted in conjunction with its implementation. Different approaches, of course, would "divide up the burden of curtailment among the four Upper Division states in different ways."257 Although not on the Upper Colorado River Commission's front burner at present, the need to develop Article IV guidelines has been recognized, and pursued to an extent, in recent years. Specifically, the Commission's Engineering Advisory Committee began efforts several years ago to draft "Principles for Administration of Consumptive Uses under the Upper Colorado River Basin Compact" that would have set guidelines for Article IV's administration. ${ }^{258}$ These efforts were eclipsed when formulation of drought contingency plans-plans aimed at avoiding, rather than administering, a Compact call and curtailment as described below-assumed priority. ${ }^{259}$ No doubt a slew of issues, interpretive and otherwise, would need to be addressed to implement Article IV. ${ }^{260}$ Examples include: (1) To what extent does the Compact govern groundwater rights such that they would be subject to curtailment?, and (2) What is the actual cutoff date under Article VIII of the Compact for segregating present perfected rights to be left unimpaired in a curtailment-November 24, 1922, per Article IV, or June 25, 1929, per the Arizona $v$. California decree? ${ }^{261}$ The latter question also speaks to an intrastate priority: the need for accurate inventories of present perfected rights within Upper

257. Kuhn, supra note 171 , at 12 .

258. WYo. STATE ENG'R's OFFICE, COLORADO RIVER COMPACT ADMINISTRATION Program: Consumptive Use Determination Plan 5 (2008) [hereinafter SEO PLAN].

259. Telephone Interview with Steve Wolff, Colo. River Coordinator, Wyo. State Eng'r's Office (Aug. 3, 2015) [hereinafter Wolff Interview I]; Shields Interview I, supra note 209.

260. See SEO PLAN, supra note 258, at 5 (listing issues); Kuhn, supra note 171, at 12-13 (discussing alternate Article IV approaches).

261. Decree, supra note 156 , at art. $\mathrm{I}(\mathrm{H})$. 
Division states.

Also related to Compact call and curtailment administration is a second line of developments involving water banking and temporary transfers. These measures fall within the demand management strand of avoidance measures (drought contingency planning) as well, but their connection with Article IV involves present perfected rights.

Put simply, the distribution of present perfected rights within Upper Division states is precarious from a curtailment risk perspective. As described by the Wyoming State Engineer's Office regarding that state's distribution: "The majority of agricultural water rights have priority dates prior to 24 November 1922. The majority of municipal and industrial water rights have priority dates after 24 November 1922."262 This pattern is not unique to the Cowboy State. Colorado's breathtaking Western Slope contains agricultural districts as well as several municipalities with significant pre-1922 rights. ${ }^{263}$ The same cannot be said, however, along the populous Front Range, where a curtailment could severely impact major municipal suppliers like Denver Water, whose transmountain diversions rest on post-1922 rights. ${ }^{264}$ And Cheyenne and Denver are not anomalies. Post-1922 rights likewise underpin transmountain diversions serving Salt Lake City, Albuquerque, and Santa Fe. ${ }^{265}$

Upper Division states have responded to this risk allocation dynamic in recent years by mapping out water banking and temporary transfer arrangements aimed at insulating critical water uses dependent on post-1922 rights from Compact calls and curtailments. ${ }^{266}$ Holders of such rights would be able to utilize these arrangements to access water secured under pre-1922 rights during curtailments. The genesis of these arrangements marks an important aspect of intrastate curtailment preparation. Further, although efforts thus far have taken place at the state level, it is possible that

262. SEO PLAN, supra note 258 , at 9 .

263. Kuhn, supra note 171, at 22 .

264. Id. at $22-23$.

265. Id. at 23. Transmountain diversions in Upper Division states ranged from 510,410 to 994,857 acre-feet annually between 1994 and 2015. UCRC 2015 REPORT, supra note 50, at 144.

266. See Kuhn, supra note 171, at 37-39 (Colorado water bank); SEO PLAN, supra note 258, at 13, 19 (Wyoming temporary transfers). A Wyoming water bank study is ongoing. Wolff Interview I, supra note 259. 
an integrated, multi-state bank may later emerge, ${ }^{267}$ an idea proposed in the Basin Study. 268

A final emergent administrative strand concerns consumptive use measurements. At the interstate level, a three-phase Upper Colorado River Commission Consumptive Use Study is underway. Its aim is to review the Upper Division states' and Bureau of Reclamation's methodologies for measuring agricultural consumptive use in the Upper Basin, and to evaluate possible utilization of remote sensing technologies for this purpose. 269 These measurements are considered essential to "[e]fficient administration of the Colorado River Compact" as well as "any future negotiations on shortage allocations." 270 A Phase I report was released in 2013 identifying differences in the states' and Bureau's consumptive use measurement methods, and recommending development of a consistent protocol for the Upper Basin. ${ }^{271}$ Three years later a Phase II report appeared, generally addressing extended climate stations, eddy covariance towers, and remote sensing of irrigated areas throughout the Upper Basin. ${ }^{272}$ Beyond these interstate developments, individual Upper Division states have worked for two decades on improving monitoring and measurement of consumptive use of Colorado River System water. ${ }^{273}$ All of these steps serve to facilitate Article IV's administration.

267. Kuhn, supra note 171 , at 39.

268. U.S. BurEau of REClamation, Colorado River Basin WATER SuPPly AND Demand Study, Technical Report F - DeVElopment of Options AND STRATEGIES F-59 to -60 (2012), http://www.usbr.gov/lc/region/programs/ crbstudy/finalreport/Technical\%20Report\%20F\%20-\%20Development\%20of\% 200ptions\%20and\%20Stategies/TR-F_Development_of_Ops\&Strats_FINAL.pdf [https://perma.cc/PJ3W-ECKU] [hereinafter TECHNICAL REPORT F].

269. URS, Assessing AgRICUltural Consumptive Use InCluding REMOTE SEnsing OF ACTUAL Evapotranspiration IN THE UPPER COlORADO RIVER BASIn, PhASE 2 REPORT ES-1 (2016) [hereinafter PHASE 2 REPORT]. Irrigated agriculture accounts for more than eighty percent of Upper Basin consumptive use. $I d$. at 1-3 to -4 .

270. Id. at 1-3.

271. URS, Assessing Agricultural Consumptive Use IN the UpPeR COLORADO RIVER BASIN ES-2 to -6 (2013).

272. See PHASE 2 REPORT, supra note 269, at ES-1 to -5 (summarizing report's coverage and recommendations).

273. See SEO PLAN, supra note 258, at 4 (discussing Colorado's Decision Support Systems and Wyoming's Consumptive Use Determination Plan). 


\section{b. Avoidance: Drought Contingency Planning}

Efforts to avoid a Compact call and curtailment-as well as critical elevations at Lake Powell-have gained even more traction over the past several years than the administrative developments above. The Basin States' Agreement seems to have swayed these priorities. As described earlier, this agreement does not preclude Compact litigation-including over Article III(c)—between now and December 31, 2025. But it does mandate consultation beforehand and is replete with text askewing "judicial or administrative proceedings." 274 The collaborative nature of this agreement appears to have allayed concerns in Upper Division states, at least to an extent, about a Compact call being made while the Interim Guidelines are in place. ${ }^{275} \mathrm{~A}$ shift away from curtailment administration and toward curtailment avoidance thus has occurred, with "avoidance" encompassing the maintenance of Lake Powell's storage for hydropower generation and revenues and insurance for the Article III(c) and (d) flow obligations. 276 "Drought contingency planning" is the immediate means to these ends. ${ }^{277}$ Working through the Upper Colorado River Commission, the Upper Division states have been developing a drought contingency plan since June 2013 involving three components: (1) augmentation, (2) extended and coordinated reservoir operations, and (3) voluntary demand management. 278

Neither the augmentation nor reservoir operation components of the plan require detail. Weather modification is the former's focus. ${ }^{279}$ And the latter calls for a "uniform plan" for extending and coordinating operations of the large-scale Colorado River Storage Project infrastructure: Glen Canyon Dam and Lake Powell, Flaming Gorge Dam and Reservoir, Navajo Dam and Reservoir, and the Aspinall Unit. ${ }^{280}$ The

274. Basin States' Agreement, supra note 158, at 10.

275. Shields Interview I, supra note 209.

276. Wolff Interview I, supra note 259.

277. Drought contingency planning falls within a suite of ongoing efforts-key elements of which are the Basin Study and its Moving Forward programaddressing water management in and around the basin. See PHASE I REPORT, supra note 5 , at 2-3 to -5 (surveying efforts).

278. UCRC 2015 REPORT, supra note 50, at 38.

279. Id. at 137 (containing resolution supporting expanded "geographical and temporal extent of weather modification programs").

280. Id. 
plan's express goals are to (1) “[r]educe any long-term risk of impairing annual consumptive uses due to compact curtailments in the Upper Basin," and (2) "[h]elp avoid or mitigate impacts from Lake Powell reaching the critical, minimum power pool elevation."281 A memorandum of understanding is currently being drafted addressing the plan's operational details. ${ }^{282}$

The drought contingency plan's demand management component is more nuanced. It concerns developing and implementing "temporary, voluntary, compensated" demand management programs within the Upper Basin. ${ }^{283}$ Its goal mirrors that of the reservoir operation plan: "to protect against impacts from Lake Powell reaching critical elevations and to help ensure ongoing compliance with the Colorado River Compact without impairing the right to exercise any existing water rights in the future." 284 Demand management programs may stem from three sources. The Basin Study and its Moving Forward effort are an initial source. ${ }^{285}$ A second source consists of intrastate demand management measures in Upper Division states $^{286}$ (e.g., intrastate water banking and temporary transfer arrangements emerging to address the distribution of pre- and post-1922 water rights). ${ }^{287}$ In addition, a third source involves pilot programs like the "Pilot System Conservation Program" implemented in July 2014 . $^{288}$ This program is a joint

281. Id.

282. Telephone Interview with Steve Wolff, Colo. River Coordinator, Wyo. State Eng'r's Office (Aug. 15, 2016) [hereinafter Wolff Interview II].

283. UCRC 2015 REPORT, supra note 50, at 137.

284. Id.

285. Id. See TeChNiCAL RePorT F, supra note 268, at F-22 to -27, F-38 to -46 , F-46 to -54, F-63 to -67 (addressing reuse, municipal and industrial water conservation, agricultural water conservation, and water transfers, exchanges, and banking).

286. UCRC 2015 REPORT, supra note 50, at 137.

287. See supra section III.C.2.a.

288. UCRC 2015 REPORT, supra note 50, at 137; see generally AGREEMENT Among the United States of America, Through the Department of the INTERIOR, BUREAU OF RECLAMATION, THE CENTRAL ARIZONA WATER CONSERVATION District, THE MEtropolitan Water District of SOUTHeRn California, Denver Water, AND the Southern Nevada Water Authority, For a Pilot Program For Funding the Creation of Colorado River System Water Through Voluntary Water CONSERVATION AND REDUCTIONS IN USE (July 30, 2014), http://cwcb.state.co.us/Documents/ShortTermHomePage/ 25fundingagreement.pdf [https://perma.cc/E2ST-UNXB] [hereinafter CRSCP Agreement]; see also Pilot System Conservation Program (Pilot Program), U.S. BUREAU OF RECLAMATION, http://www.usbr.gov/lc/region/programs/ 
effort of the Bureau of Reclamation and four municipal suppliers: Denver Water in the Upper Basin, and the Central Arizona Water Conservation District (again, CAWCD), Metropolitan Water District of Southern California (MWD), and Southern Nevada Water Authority (SNWA) in the Lower Basin. 289 Under the program, agricultural, municipal, and industrial users are "compensated for voluntary reductions in water use, including the fallowing of agricultural lands or increased water efficiency." 290 A total of $\$ 3.75$ million in funding has been made available for projects in the Upper Basin, ${ }^{291}$ and the Upper Colorado River Commission currently administers this part of the program. ${ }^{292}$ It selected twentyeight projects for funding in 2015 and 2016-a total expenditure of $\$ 2.5$ million aimed at conserving at least 11,300 acre-feet. ${ }^{293}$ Truly conceived as a pilot, ${ }^{294}$ the Upper Basin component of the program will extend to September 30, 2017, at which time there will be a "hard stop" to evaluate its future, including possibly its long-term administration. ${ }^{295}$

To summarize, the structural relationship between the Compact and Upper Basin Compact places the Upper Division states in a position of making do with whatever leftovers remain available for consumptive use after satisfying the Article III(c) and (d) flow obligations. This dynamic has been a defining quality of the allocation framework since Meyers

PilotSysConsProg/pilotsystem.html (last visited Aug. 16, 2016) [https://perma.cc/ 9BDQ-CTKR] [hereinafter Pilot Program].

289. CRSCP Agreement, supra note 288, at 1.

290. Id. at 6 .

291. $\$ 2.75$ million in initial funding was made available in July 2014. Pilot Program, supra note 288. An additional \$1 million was made available in 2016. Telephone Conversation with Jane Bird, Legal Counsel, Upper Colo. River Comm'n (Aug. 17, 2016).

292. See generally UPPER COLO. River COMM'N, AgreEMEnT to FACILITATE the System Conservation Pilot Program in the UPPER Colorado River BASIN (May 13, 2015) (outlining commission's administrative obligations) (on file with author).

293. UCRC 2015 REPORT, supra note 50, at 8.

294. See CRSCP Agreement, supra note 288, at 1, 9, 13 (identifying program's expiration as either July 30, 2016, or December 31 of the year in which the latest implementation agreement expires, and calling for subsequent program evaluation and possible extension or adoption of long-term program).

295. Wolff Interview II, supra note 282; see also UPPER COLO. RIVER COMM'N, Request For Proposals Regarding a Potential Funding OPPORTUNity For Voluntary Participation in a Pilot System Water Conservation Program (Oct. 5, 2016), http://www.ose.state.nm.us/Basins/Colorado/PDF/2017\%20SCPP\% 20RFP.pdf [https://perma.cc/L9AL-5C4Y] (soliciting project proposals for 2017). 
published The Colorado River fifty years ago. And, despite the historic drought, the Upper Division states' gradually increasing use of the leftovers has yet to precipitate a Compact call and curtailments. Precisely how Article IV would be implemented (and interpreted) is unclear as an administrative matter, though undoubtedly clutch given the provision's insulation of pre-1922 rights from curtailment. Continuing progress nonetheless is being made with curtailment-oriented intrastate water banking and temporary transfer arrangements, and consumptive use measurements throughout the Upper Basin. Even more pressing on the priority list is the Upper Division states' evolving drought contingency plan, with its augmentation, reservoir operation, and demand management components. The plan's combined goal of avoiding Compact calls, curtailments, and critical elevations at Lake Powell has emerged as paramount in contemporary timesagain, a direct outgrowth of the allocation framework's existing design. For a structural dynamic posing equal or arguably greater consternation, one need only set eyes below Lee Ferry.

\section{Arizona v. California Decree}

"As Judge Simon Rifkind, the Special Master in Arizona $v$. California, once had occasion to remark, the problems of the river would be solved if only the scientists could turn words into water." 296 Meyers shared this quip from his former boss three years after the Supreme Court's decision in 1963. ${ }^{297}$ Even more so today, it would be a monumental feat if the Special Master's transformation indeed could be worked. Until then, allocational conditions along the Lower Colorado River foreseeably will remain as tight as they have ever been. A disjuncture exists between the amount of water supplied to the Lower Division states pursuant to the Compact's flow obligations, and the amount of water to which these states have grown accustomed under the Arizona $v$. California decree. This disjuncture poses the prospect of recurring shortages in the Lower Basin. Keen on avoiding constraints on consumptive use imposed during shortages-as well as maintaining hydropower production at Hoover Dam-a range of responses

296. Meyers, supra note 14, at 38.

297. Id. at 37 . 
began emerging in the late 1990s aimed at bolstering Lake Mead's storage to avoid shortages and enabling Lower Division states to mitigate the impacts of shortage-based rationing. Further, as in the Upper Basin, clarity regarding shortage administration under the Arizona $v$. California decree also has surfaced as a priority during this period. After sketching out the Lower Colorado River apportionment, this section sheds light on the dynamic and varied milestones of this constrained yet pioneering branch of the allocation framework's evolution.

\section{Lower Colorado River Apportionment}

The Arizona $v$. California decree's apportionment for the Colorado River mainstream below Lee Ferry is perhaps the most complex of the four schemes comprising the Law of the River's allocation framework. It is rooted in the Supreme Court's landmark 1963 decision. ${ }^{298}$ Not without dissent and critical commentary, ${ }^{299}$ that decision interpreted the Boulder Canyon Project Act as having established the scheme through a statutory apportionment, and concluded the Colorado River Compact did not play a controlling role vis-à-vis the scheme's make-up. ${ }^{300}$ To be clear, the apportionment solely accounts for consumptive use of water from the Lower Colorado River itself, and is inapplicable to Lower Basin tributaries. ${ }^{301}$

The apportionment's core appears in Article II of the Court's decree. It takes a sliding-scale approach when defining the Lower Division states' apportionments. Their scope varies annually based upon a declaration by the Secretary of the Interior regarding the amount of mainstream water available for consumptive use. The Secretary may declare three types of conditions under the decree: normal, surplus, or shortage. When there is sufficient water to satisfy 7.5 maf of consumptive use in the Lower Division states, normal conditions exist and the decree divvies out 2.8 maf to Arizona,

298. 373 U.S. 546 (1963).

299. Id. at 603-27 (Harlan, J., dissenting); id. at 627-46 (Douglas, J., dissenting). For an insightful contemporary perspective on the decision, see Lawrence J. MacDonnell, Arizona v. California: Its Meaning and Significance for the Colorado River and Beyond After Fifty Years, 4 ARIZ. J. ENVTL. L. \& POL'Y 88 (2014).

300. Arizona v. California, 373 U.S. at 564-67.

301. Decree, supra note 156 , at art. VIII(B). The decree does govern New Mexico's use of the Gila River. Id. at art. IV(A)-(F). 
4.4 maf to California, and 0.3 maf to Nevada. ${ }^{302}$ If supplies allow for more than 7.5 maf of consumptive use, the decree calls for sharing this surplus on a percentage basis: Arizona, 46\%; California, 50\%; and Nevada, 4\%.303 Finally, in the event of shortage conditions wherein less than 7.5 maf of mainstream water is available for consumptive use, the decree calls for two measures. First, the Secretary of the Interior must satisfy "present perfected rights in the order of their priority dates without regard to state lines." 304 Second, after consulting with state representatives and major entitlement holders, the Secretary has discretion to apportion water remaining available for consumptive use. ${ }^{305}$ The Secretary's discretion is confined, however, by two limitations. On one hand, the decree proscribes more than 4.4 maf being apportioned for use in California during a shortage, including all present perfected rights. ${ }^{306}$ On the other hand, the Colorado River Basin Project Act provides California's basic apportionment of 4.4 maf must be satisfied in full before any water is supplied to water users through the Central Arizona Project. ${ }^{307}$

Alongside the sliding-scale apportionment provisions is a paragraph that has played a pivotal role in facilitating innovation over the past seventeen years: Article II(B)(6). It authorizes the Secretary of the Interior to release water apportioned to, but unused in, one Lower Division state to a different Lower Division state on an annual basis. ${ }^{308}$ These reallocations do not alter the states' apportionments as mapped out above. Rather, the provision simply allows unused water within the apportionments to be temporarily utilized in a Lower Division state (e.g., California) other than the one holding the apportionment (e.g., Nevada).

Worth echoing on a final note are three features of the decree's apportionment that distinguish it from those of the Upper Basin Compact and Compact. First, the decree's "diversions less return flows" method of measuring "consumptive use" along the Lower Colorado River differs from

302. Id. at art. II(B)(1).

303. Id. at art. II(B)(2).

304. Id. at art. II(B)(3).

305. Id.

306. Id.

307. Colorado River Basin Project Act $\S 301(b), 43$ U.S.C. $§ 1521(b)$ (2012).

308. Decree, supra note 156 , at art. II(B)(6). 
the Upper Basin Compact's "inflow-outflow" method by not accounting for reservoir evaporation-again, the Compact is silent here. ${ }^{309}$ Second, the decree's cutoff for "present perfected rights" (June 25, 1929) differs from that of the Upper Basin Compact (November 24, 1922), with the Compact lacking a definition. ${ }^{310}$ Third, the decree's treatment of groundwater is novel. Its apportionment expressly accounts for "water drawn from the mainstream by underground pumping." 311 Neither compact contains an analogue. Although notable in differentiating the Law of the River's domestic apportionments, these distinctions of course should not obscure the constriction collectively created by the apportionments within the Lower Basin. It is a tight space, and portends to become even more so, as revealed below.

\section{Structural Deficit \& Shortages}

Having originated shortly before The Colorado River, the Arizona $v$. California decree's apportionment has since facilitated a scale of reliance in the Lower Division states as sobering as the "peopling" figures in Part II. Further, according to the Basin Study, the dependence of these states on Lower Colorado River water is projected over the next several decades to surpass anything ever seen. A few figures are illustrative. From 1971 to 2010, the Lower Division states' consumptive use of mainstream water increased from approximately 6.56 maf in the former year to 7.40 maf in the latter one, peaking at roughly 8.41 maf in 2002. ${ }^{312}$ Excluded from these figures are reservoir evaporation ranging from approximately 750,000 acre-feet to 1.3 maf annually, and phreatophyte losses ranging from slightly above 300,000 acre-feet to slightly above 650,000 acre-feet annually. ${ }^{313}$ As of the Bureau of Reclamation's most recent water accounting report in 2015, the Lower Division states' consumptive use was approximately 7.45 maf, excluding reservoir evaporation and other losses. ${ }^{314}$ Looking forward, the VI.

309. Compare id. at art. I(A), with Upper Basin Compact, supra note 20, at art.

310. Compare Decree, supra note 156, at art. I(H), with Upper Basin Compact, supra note 20 , at art IV(c).

311. Decree, supra note 156 , at art. I(C).

312. TECHNICAL REPORT C, supra note 35, at C-8 fig.C-3.

313. Id. at C-48 fig.C-19, C-49 fig.C-20.

314. 2015 ACCOUNTING, supra note 149 , at 5 tbl.1. 
trajectory of demands for Lower Colorado River water projected in the Basin Study apparently entails a ramp-up of the historical trend. These demands are expected to range from slightly above 8.0 maf to slightly below 9.0 maf by 2035 , and to climb somewhere between slightly below 9.0 maf and slightly above 10.0 maf by 2060, again excluding reservoir evaporation and other losses. ${ }^{315}$ It is ironic that, although the Supreme Court declined to interpret the Compact in Arizona $v$. California, it is nonetheless the Article III(c) and (d) flow obligations that largely will determine the realism of these projections and relative security of existing uses.

Just as the Article III(c) and (d) flow obligations constrain the leftovers available for apportionment among the Upper Division states under the Upper Basin Compact, so too do these obligations constrain the flows available for apportionment among the Lower Division states under the Arizona $v$. California decree. One might say "reciprocal constraint" exists. Its adherence along the Lower Colorado River is paramount in contemporary times and manifests as the "structural deficit." To elaborate briefly, notwithstanding tributary inflows below Lee Ferry, the Lower Colorado River's primary source of supply consists of Lake Powell releases made in fulfillment of the Article III(c) and (d) flow obligations-again, as currently implemented by the Interim Guidelines. Prior to the guidelines, the historical minimum objective release from Lake Powell had been 8.23 maf per year under the Long-Range Operating Criteria. ${ }^{316}$ Pursuant to the guidelines, this figure now can be as low as 7.0 maf. ${ }^{317}$ The existential problem is that these volumes fall squarely short of what is needed to enable the Lower Division states' to utilize their basic 7.5 maf apportionment in the Arizona $v$. California decree for normal conditions. Thus, as the Director of the Arizona Department of Water Resources has testified, "a 'structural deficit' in the water supplies available from Lake Mead to California, Nevada, Arizona, and Mexico exists as an artifact of the "Law of the River." 318 "[I]n a normal year a set amount of water flows

315. TeCHNiCAL RePoRT C, supra note 35, at C-26 fig.C-9.

316. LROC, supra note 205, at art. II(2).

317. INTERIM GUIDELINES ROD, supra note 158 , at 57 .

318. Testimony of Thomas Buschatzke, Dir., Ariz. Dep't of Water Res., before U.S. Senate Comm. on Energy and Nat. Res. 2-3 (June 2, 2015), http://www.energy.senate.gov/public/index.cfm/files/serve?File_id=6fcd8b5d-b4cd- 
into Lake Mead[,] but it is not enough to cover releases for use, evaporation and delivery losses." 319 A general rule of thumb for normal conditions is that "if Lake Powell releases 8.23 maf, Lake Mead will lose about a million acre[-]feet of storage per year." 320 As detailed below in Table 6, figures since the historic drought's onset largely bear out this rule. Over the fifteen-year period from 2000 to 2015, annual Lake Powell releases averaged 8.70 maf, annual consumptive uses in the Lower Division states averaged 7.57 maf, and Lake Mead's elevation declined an annual average of 839,600 acre-feet (i.e., plummeting from 22.444 to 9.85 maf). ${ }^{321}$

4956-b0e1-574bfc65ebb5 [https://perma.cc/GSM9-AL9B].

319. Id. at 3 .

320. Kuhn, supra note 171, at 34; see also CENT. ARIZ. PROJECT, 2015 YeAR IN REVIEW 2 (2015), http://www.cap-az.com/documents/departments/finance/ CAP_2015-YIR-OFA.pdf [https://perma.cc/YFH2-7GQZ] [hereinafter CAP 2015 REVIEW] (describing structural deficit as about 1.2 maf).

321. These figures are drawn from the sources cited infra note 322. 
Table 6. Lake Powell Releases, Lower Basin Mainstream Consumptive Use, and Lake Mead Storage

\begin{tabular}{|r|r|r|r|}
\hline & Lake Powell Release & Lower Basin Use & Lake Mead Storage \\
\hline 2000 & $9.40 \mathrm{maf}$ & $8.0254 \mathrm{maf}$ & $22.444 \mathrm{maf}$ \\
\hline 2001 & $8.23 \mathrm{maf}$ & $8.1704 \mathrm{maf}$ & $19.873 \mathrm{maf}$ \\
\hline 2002 & $8.23 \mathrm{maf}$ & $8.4068 \mathrm{maf}$ & $17.093 \mathrm{maf}$ \\
\hline 2003 & $8.23 \mathrm{maf}$ & $7.537737 \mathrm{maf}$ & $15.618 \mathrm{maf}$ \\
\hline 2004 & $8.23 \mathrm{maf}$ & $7.383836 \mathrm{maf}$ & $13.937 \mathrm{maf}$ \\
\hline 2005 & $8.23 \mathrm{maf}$ & $7.064505 \mathrm{maf}$ & $15.219 \mathrm{maf}$ \\
\hline 2006 & $8.23 \mathrm{maf}$ & $7.411029 \mathrm{maf}$ & $13.89 \mathrm{maf}$ \\
\hline 2007 & $8.231 \mathrm{maf}$ & $7.45433 \mathrm{maf}$ & $12.51 \mathrm{maf}$ \\
\hline 2008 & $8.978 \mathrm{maf}$ & $7.520961 \mathrm{maf}$ & $12.01 \mathrm{maf}$ \\
\hline 2009 & $8.23 \mathrm{maf}$ & $7.438398 \mathrm{maf}$ & $10.933 \mathrm{maf}$ \\
\hline 2010 & $8.23 \mathrm{maf}$ & $7.378643 \mathrm{maf}$ & $10.09 \mathrm{maf}$ \\
\hline 2011 & $12.52 \mathrm{maf}$ & $7.316616 \mathrm{maf}$ & $12.98 \mathrm{maf}$ \\
\hline 2012 & $9.47 \mathrm{maf}$ & $7.443546 \mathrm{maf}$ & $13.14 \mathrm{maf}$ \\
\hline 2013 & $8.23 \mathrm{maf}$ & $7.478219 \mathrm{maf}$ & $12.36 \mathrm{maf}$ \\
\hline 2014 & $7.48 \mathrm{maf}$ & $7.649011 \mathrm{maf}$ & $10.12 \mathrm{maf}$ \\
\hline 2015 & $9.00 \mathrm{maf}$ & $7.448217 \mathrm{maf}$ & $9.85 \mathrm{maf}$ \\
\hline
\end{tabular}

Sources $^{322}$

322. Lake Powell Releases: U.S. BurEau of Reclamation, ANNUAL OPERATING PLAN FOR COLORADO RIVER RESERVOIRS 2016, at 18 (2016), http://www.usbr.gov/lc/region/g4000/aop/AOP16.pdf [https://perma.cc/6JW3NUH5] [hereinafter 2016 AOP]; U.S. BUREAU OF RECLAMATION, ANNUAL OPERATING PLAN FOR COLORADO RIVER RESERVOIRS 2015, at 17 (2015), http://www.usbr.gov/uc/water/rsvrs/ops/aop/AOP15.pdf [https://perma.cc/7BU8NS62] [hereinafter 2015 AOP]; U.S. BUREAU OF RECLAMATION, ANNUAL OPERATING PLAN FOR COLORADO RIVER RESERVOIRS 2014, at 18 (2014), http://www.usbr.gov/lc/region/g4000/aop/AOP14.pdf [https://perma.cc/8N39-YPBY] [hereinafter 2014 AOP]; U.S. BUREAU OF RECLAMATION, ANNUAL OPERATING PlaN FOR COLORADO RIVER RESERVOIRS 2013, at 16-17 (2013), http://www.usbr.gov/uc/water/rsvrs/ops/aop/AOP13_final.pdf [https://perma.cc/ 6FWH-HXAM] [hereinafter 2013 AOP]; U.S. BUREAU OF RECLAMATION, ANNUAL OPERATING Plan FOR COLORADO RIVER RESERVOIRS 2012, at 18 (2012), http://www.usbr.gov/lc/region/g4000/aop/AOP12.pdf [https://perma.cc/GMR2U8P3] [hereinafter 2012 AOP]; U.S. BUREAU OF RECLAMATION, ANNUAL OPERATING PLAN FOR COLORADO RIVER RESERVOIRS 2011, at 16 (2011), http://www.usbr.gov/uc/water/rsvrs/ops/aop/AOP11_final.pdf [https://perma.cc/ 7HH4-SY4E] [hereinafter 2011 AOP]; U.S. BUREAU OF RECLAMATION, ANNUAL OPERATING PLAN FOR COLORADO RIVER RESERVOIRS 2010, at 18 (2010), http://www.usbr.gov/lc/region/g4000/AOP2010/AOP10.pdf [https://perma.cc/6UYA- 
WNUT] [hereinafter 2010 AOP]; U.S. BUREAU OF RECLAMATION, ANNUAL OPERATING PLAN FOR COLORADO RIVER RESERVOIRS 2009, at 17 (2009), http://www.usbr.gov/lc/region/g4000/aop/AOP09.pdf [https://perma.cc/AY2UKJKC] [hereinafter 2009 AOP]; U.S. BUREAU OF RECLAMATION, ANNUAL OPERATING PLAN FOR COLORADO RIVER RESERVOIRS 2008, at 16 (2008), http://www.usbr.gov/lc/region/g4000/AOP2008/AOP08_Final.pdf [https://perma.cc/ ZUL4-PDVK] [hereinafter 2008 AOP]; U.S. BUREAU OF RECLAMATION, ANNUAL OPERATING PLAN FOR COLORADO RIVER RESERVOIRS 2007, at 16 (2007), http://www.usbr.gov/lc/region/g4000/aop/AOP07.pdf [https://perma.cc/NE75UQKE] [hereinafter 2007 AOP]; U.S. BUREAU OF RECLAMATION, ANNUAL OPERATING PLAN FOR COLORADO RIVER RESERVOIRS 2006, at 18 (2006), http://www.usbr.gov/lc/region/g4000/AOP2006/aop06_final.pdf [https://perma.cc/ TEJ4-RU9C] [hereinafter 2006 AOP]; U.S. BUREAU OF RECLAMATION, ANNUAL OPERATING PLAN FOR COLORADO RIVER RESERVOIRS 2005, at 15 (2005), http://www.usbr.gov/lc/region/g4000/aop/AOP05.pdf [https://perma.cc/2LT8-8XJY] [hereinafter 2005 AOP]; U.S. BUREAU OF RECLAMATION, ANNUAL OPERATING PLAN FOR COLORADO RIVER RESERVOIRS 2004, at 15 (2004), http://www.usbr.gov/ lc/region/g4000/aop/AOP04.pdf [https://perma.cc/43JA-SZMR] [hereinafter 2004 AOP]; U.S. Bureau of Reclamation, ANNuAl Operating Plan For COlORAdo RIVER RESERVOIRS 2003, at 14 (2003), http://www.usbr.gov/lc/region/g4000/aop/ AOP03.pdf [https://perma.cc/QX49-LHAP] [hereinafter 2003 AOP]; U.S. BUREAU of Reclamation, ANNUAl OPERATing Plan For COLORADO River REsERVoirs 2002, at 11 (2002), http://www.usbr.gov/lc/region/g4000/aop/AOP02.pdf [https://perma.cc/U6PN-449S] [hereinafter 2002 AOP]; U.S. BUREAU OF REClamation, ANNUAL OPERATING PlAN FOR COLORADO RIVER RESERVOIRS 2001, at 11 (2001), http://www.usbr.gov/lc/region/g4000/aop/AOP01.pdf [https://perma.cc/PQP9-ME73] [hereinafter 2001 AOP]. Lower Basin Management Consumptive Use: 2015 ACCOUNTING, supra note 149, at 5 tbl.1; 2014 ACCOUNTING, supra note 150, at 5 tbl.1; 2013 ACCOUNTING, supra note 150, at 2; 2012 ACCOUNTING, supra note 150, at 2; 2011 ACCOUNTING, supra note 150, at 2; U.S. BUREAU OF REClAMATION, COLORADO RIVER ACCOUNTING AND WATER USE REPORT ARIZONA, CALIFORNIA, AND NEVADA 2 (2010), http://www.usbr.gov/lc/ region/g4000/4200Rpts/DecreeRpt/2010/2010.pdf [https://perma.cc/KPQ4-87GL] [hereinafter 2010 ACCOUNTING]; U.S. BUREAU OF RECLAMATION, COLORADO River ACCOUnTING AND WATER Use REPORT ARIZONA, CALIFORNIA, AND NEVADA 2 (2009), http://www.usbr.gov/lc/region/g4000/4200Rpts/DecreeRpt/2009/2009.pdf [https://perma.cc/W93U-6UH2] [hereinafter 2009 ACCOUNTING]; U.S. BUREAU OF Reclamation, COlORAdo RIVER ACCOUNTING AND WATER UsE REPORT ARIZONA, CALIFORNIA, AND NEVADA 2 (2008), http://www.usbr.gov/lc/region/g4000/ 4200Rpts/DecreeRpt/2008/2008.pdf [https://perma.cc/QK99-8KRM] [hereinafter 2008 ACCOUNTING]; U.S. BUREAU OF REClamation, COlORADO River ACCounting AND Water Use Report ARIzona, CAlifornia, AND Nevada 2 (2007), http://www.usbr.gov/lc/region/g4000/4200Rpts/DecreeRpt/2007/2007.pdf [https://perma.cc/H228-GR86] [hereinafter 2007 ACCOUNTING]; U.S. BUREAU OF RECLAMATION, COLORADO RIVER ACCOUNTING AND WATER USE REPORT ARIZONA, CALIFORNIA, AND NEVADA 2 (2006), http://www.usbr.gov/lc/region/g4000/ 4200Rpts/DecreeRpt/2006/2006.pdf [https://perma.cc/Z8PV-FPNF] [hereinafter 2006 Accounting]; U.S. Bureau OF REClamation, Colorado River ACCOUNTING AND WATER USE REPORT ARIZONA, CALIFORNIA, AND NEVADA 2 (2005), http://www.usbr.gov/lc/region/g4000/4200Rpts/DecreeRpt/2005/2005.pdf [https://perma.cc/AE4A-PTLQ] [hereinafter 2005 ACCOUNTING]; U.S. BUREAU OF ReClamation, COlorado RIVER ACCOUNTING AND WATER Use REPORT ARIzONA, CALIFORNIA, AND NEVADA 2 (2004), http://www.usbr.gov/lc/region/g4000/ 
The structural deficit poses the prospect of recurring shortages along the Lower Colorado River under the Arizona $v$. California decree. If future Lake Powell releases average 8.23 maf (or less) per year, then on a consistent basis less than 7.5 maf will be available for consumptive use by the Lower Division states. Although a shortage has not been declared in the half-century since the decree's issuance, the Secretary of the Interior released only 7.48 maf from Lake Powell in 2014an unprecedented drop below the historical 8.23 maf minimum objective release since the reservoir's filling in the 1980 s. $^{323}$ Further, as noted earlier, recent Bureau of Reclamation projections identify upwards of a sixty-percent shortage probability over the next several years. ${ }^{324}$ In the big picture, "[i]t's really not a question of if, but when," 325 a shortage declaration will be made, given the combined or perhaps even

4200Rpts/DecreeRpt/2004/2004.pdf [https://perma.cc/WD9L-AQDP] [hereinafter 2004 ACCOUNTING]; U.S. BUREAU OF REClamation, ACCOUNTING FOR COLORADO River Water Use Within the States of ARIZONA, CAlifornia, AND NEVAda 2 (2003), http://www.usbr.gov/lc/region/g4000/4200Rpts/DecreeRpt/2003/2003.pdf [https://perma.cc/72CG-M57N] [hereinafter 2003 ACCOUNTING]; U.S. BUREAU OF REClamation, COMPILATION OF RECORDS in ACCORDANCE WiTH ARTICLE V OF THE DeCREe OF THE SuPREMe COURT OF THE United STATES IN ARIZONA V. CALIFORNIA ET AL. 1 (2002), http://www.usbr.gov/lc/region/g4000/4200Rpts/ DecreeRpt/2002DecreeRpt.pdf [https://perma.cc/9UEU-J23W] [hereinafter 2002 ACCOUNTING]; U.S. BUREAU OF RECLAMATION, COMPILATION OF RECORDS IN ACCordance With ARticle V of the Decree of the Supreme Court of the United StATES IN ARIZONA V. CALIFORNIA ET AL. DATED MARCH 9, 19641 (2001), http://www.usbr.gov/lc/region/g4000/4200Rpts/DecreeRpt/2001DecreeRpt.pdf [https://perma.cc/VH7F-3WVE]; U.S. BUREAU OF RECLAMATION, COMPILATION OF RECORDS IN ACCORDANCE WITH ARTICLE V OF THE DECREE OF THE SUPREME Court of the United States in ARIzona V. CALIFornia DATED March 9, 19641 (2000), http://www.usbr.gov/lc/region/g4000/4200Rpts/DecreeRpt/2000Decree Rpt.pdf [https://perma.cc/A3W9-U9JZ]. Lake Mead Storage: 2016 AOP, supra, at 8 tbl.1; 2015 AOP, supra, at 20; 2014 AOP, supra, at 20; 2013 AOP, supra, at 21; 2012 AOP, supra, at $21 ; 2011$ AOP, supra, at $22 ; 2010$ AOP, supra, at 9 tbl.1; 2009 AOP, supra, at 21; 2008 AOP, supra, at 20; 2007 AOP, supra, at 20; 2006 AOP, supra, at 22; 2005 AOP, supra, at 5 tbl.1(a); 2004 AOP, supra, at 7 tbl.1(a); 2003 AOP, supra, at 6 tbl.1(a); 2002 AOP, supra, at 4 tbl.1(a); 2001 AOP, supra, at 4 tbl.1(b).

323. Cent. Ariz. Project, Colorado River Water Supply AND 24-Month STUDY 1 (2013), http://www.cap-az.com/documents/public-information/24-monthstudy-FactSheet_ColRiver.pdf [https://perma.cc/6BEB-842K].

324. ShorTAGE Projections, supra note 141, at 6.

325. Aaron Orlowski, Orange County Faces More Competition for DroughtStrangled Colorado River, ORANGE COUNTY REgIsTER, March 5, 2016, http://www.ocregister.com/articles/water-707026-river-colorado.html [https://perma.cc/TV3X-4FPA] (quoting MWD Colorado River Manager Bill Hasencamp). 
singular effect of projected climate change-based reductions in Lee Ferry flows, and projected increased consumptive use in the Upper Division states. ${ }^{326}$ Policymakers have been aware of this shortage risk and structural deficit since at least the Pacific Southwest Water Plan in 1964.327 Coupled with concerns about maintaining Lake Mead's storage above critical elevations, and thereby preserving Hoover Dam's hydropower capacity and revenues, these challenges have spurred a host of developments over the past two decades involving shortage administration and avoidance.

\section{a. Administration: Shortage "Sharing"}

In which specific circumstances will the Secretary of the Interior declare a shortage under the Arizona $v$. California decree? Further, how exactly will this declaration affect each Lower Division state? The need for clarity and certainty embedded in these questions loomed large during the Interim Guidelines' formation. ${ }^{328}$ Forged in 2007, the guidelines responded to this priority with a tiered approach resembling the coordinated operating regime for Lake Powell and Lake Mead as well as Minute 319's shortage-sharing scheme.

The fact that the Interim Guidelines' shortage-sharing rules for Lake Mead track their Minute 319 successors makes sense given vocal concerns expressed during the guidelines' formation about Mexico's sharing shortages with the Lower Division states - or at least two of them as of now. ${ }^{329}$ The guidelines' shortage tiers revolve around Lake Mead's projected elevation on January 1 each year. If this elevation falls between 1,075 and 1,050 feet, 7.167 maf will be apportioned to the Lower Division states, and Arizona's and Nevada's respective apportionments will be limited to 2.48 maf and 287,000 acre-feet. ${ }^{330}$ At the next rung, if Lake Mead's elevation is projected to range from 1,050 and 1,025 feet, the total apportionment will be reduced to 7.083 maf, with Arizona's and

326. See TECHNICAL REPORT B, supra note 8, at B-66 (Lee Ferry flow decreases); TECHNICAL REPORT C, supra note 35, at C-27 fig.C-9 (consumptive use increases); Grant, supra note 212, at 982 (describing how factors suggest shortages will be "constant concern," not limited to droughts, in future).

327. WATER PLAN, supra note 84, at 10.

328. INTERIM GUIDELINES ROD, supra note 158, at 6.

329. See id. at 54 (reflecting emphasis on Mexico's sharing shortages).

330. Id. at 37 . 
Nevada's shares cut to 2.4 maf and 283,000 acre-feet, respectively. ${ }^{331}$ Finally, in the event Lake Mead's projected elevation lies below 1,025 feet, 7.0 maf will be apportioned, and Arizona's and Nevada's respective apportionments will be reduced to $2.32 \mathrm{maf}$ and 280,000 acre-feet. 332 Annual consultation is required at the bottom tier, and if Lake Mead's elevation seems likely to fall below 1,000 feet, further consultation will address instating "additional measures consistent with applicable federal law." 333

The current iteration of the Interim Guidelines' framework is just that: an iteration. At the time of this writing, the Lower Division states and Bureau of Reclamation are discussing possibly tweaking the framework as part of ongoing drought contingency planning. One key feature of the potential modifications is that California would share shortages-rather than having its 4.4 maf apportionment for normal conditions fully insulated-and accept curtailments of 200,000 to 350,000 acre-feet at various tiers if Lake Mead's projected January 1 elevation were 1,045 feet or below. ${ }^{334}$ Further, Arizona and Nevada would absorb curtailments at a new 1,090-feet tier, and Arizona likewise would shoulder higher-volume curtailments, including a 720,000 acre-feet hit if Lake Mead's projected elevation were 1,025 feet or below. ${ }^{335}$ This revised scheme will take effect by 2018 if ultimately forged. ${ }^{336}$

\section{b. Avoidance: Water Banking, ICS/DSS \& Pilot Programs}

Shifting from the Interim Guidelines' shortage administration approach, a handful of programs have arisen along the Lower Colorado River over the past two decades

331. Id.

332. Id.

333. Id. at 55 .

334. Amy McCoy, Dir., Aylward + McCoy \& Pilz Consulting LLC, Presentation at the University of Colorado Law School 2016 Martz Summer Conference: Arizona's Contributions to Address Lake Mead's Structural Deficit 6 (June 9, 2016), http://www.colorado.edu/law/sites/default/files/Amy\%20McCoy\%20Martz\% 20Conference.pptx [https://perma.cc/93QR-ADT9].

335. Id.

336. Tony Davis, Tribes, Farms Wary of Proposed Cuts in Water Deliveries from Lake Mead, LAS VEGAS Sun, July 28, 2016, http://lasvegassun.com/news/ 2016/jul/28/tribes-farms-wary-of-proposed-cuts-in-water-delive/ [https://perma.cc/ $5 \mathrm{KVW}-\mathrm{Y} 82 \mathrm{~S}]$. 
aimed at intertwined avoidance goals-namely, avoiding a shortage declaration under the Arizona $v$. California decree, preventing Lake Mead's elevation from reaching critical levels, and mitigating impacts of a shortage declaration if one were made. Harmony exists among these programs to a large extent, but as will become clear some dissonance appears inherent between the first program to originate, an interstate water banking program, and its successors.

The Lower Basin water banking program's roots trace to federal regulations promulgated in 1999.337 As alluded to above, Article II(B)(6) of the Arizona $v$. California decree is the program's linchpin, authorizing the Secretary of the Interior to release water apportioned to, but unused in, one Lower Division state to a different Lower Division state. ${ }^{338}$ At the core of the program are "storage and interstate release agreements" (SIRAs) formed by "storing entities" and "consuming entities." 339 The interactions between these parties and the Secretary generally proceed as follows. ${ }^{340}$ Initially, a storing entity stores water from the Colorado River mainstream in an off-stream reservoir or groundwater aquifer in a Lower Division state. Based on this activity, the storing entity develops "intentionally created unused apportionment" (ICUA). ${ }^{341}$ In turn, at a later time, the storing entity requests the Secretary to release the ICUA to a consuming entity in a different Lower Division state for its use. The Lower Division states' apportionments remain intact under this arrangement. ${ }^{342}$ The Secretary accounts for water stored by a storing entity as a consumptive use during the year of storage, ${ }^{343}$ and accounts for consumptive use of ICUA by a consuming entity as a consumptive use during the year the water is released. 344

Two SIRAs have been formed under the Lower Basin

337. 43 C.F.R. $\S \S 414.1-414.6$ (2016).

338. Decree, supra note 156, at art. II(B)(6).

339. See 43 C.F.R. $\S \S 414.2$, 414.3(a)(1)-(18) (2016) (defining "storing entity" and "consuming entity," and detailing SIRA features). Participation generally requires a secretarial contract under section 5 of the Boulder Canyon Project Act. Id. $\S 414.3(\mathrm{e})$.

340. See id. § 414.1(a)(1)-(4) (illuminating interactions).

341. Id. $\S 414.2$.

342. Id. $\S 414.1(\mathrm{~b})(4)$.

343. Id. § 414.4(b)(1)

344. Id. $\S 414.4(\mathrm{~b})(2)$. 
water banking program thus far. ${ }^{345}$ The first agreement arose in 2002 and involves the Arizona Water Banking Authority (AWBA) storing water from Arizona's or Nevada's decree apportionments for the SNWA's benefit. ${ }^{346}$ Formed two years later, in 2004, the second agreement similarly calls for the MWD storing water from Nevada's decree apportionment for the SNWA. ${ }^{347}$ As of the Bureau of Reclamation's most recent water accounting report in 2015, the AWBA and MWD have banked a total of 931,266 acre-feet for the SNWA under these agreements. 348 The AWBA has banked 601,041 acre-feet, 349 storing 527,520 acre-feet prior to the Interim Guidelines' Intentionally Created Surplus (ICS) program coming online in 2008, and 73,521 acre-feet thereafter. ${ }^{350}$ As for the remaining 330,225 acre-feet, the pattern is inverted: the MWD banked only 25,000 acre-feet of this water before the guidelines' ICS program commenced, and 305,225 acre-feet since then. ${ }^{351}$ Notably, beyond its interstate activities, the AWBA has engaged in intrastate banking of more than 3.4 maf since its formation in 1996. ${ }^{352}$ While these resources are golden given Arizona's and Nevada's positions under the Interim Guidelines' shortage-sharing rules described above, the roughly 4.3 maf stored through this interstate and intrastate banking is plainly not banked in Lake Mead. ${ }^{353}$ It does not stave off shortages and critical elevations.

Following on the interstate water banking program's heels,

\footnotetext{
345. 2015 ACCOUNTING, supra note 149 , at 33.

346. Id.

347. Id.

348. Id. at 34 tbl.12.

349. Id.

350. Id.; 2014 ACCOUNTING, supra note 150, at 34; 2013 ACCOUNTING, supra note 150, at 28; 2012 ACCOUNTING, supra note 150, at 27; 2011 ACCOUNTING, supra note 150 , at $27 ; 2010$ ACCOUNTING, supra note 322 , at 27; 2009 ACCOUNTING, supra note 322, at 27; 2008 ACCOUNTING, supra note 322, at 27; 2007 ACCOUNTING, supra note 322, at 29; 2006 ACCOUNTING, supra note 322, at 29; 2005 ACCOUNTING, supra note 322, at 30; 2004 ACCOUNTING, supra note 322, at 30; 2003 ACCOUNTING, supra note 322, at 32; 2002 ACCOUNTING, supra note 322 , at 36 .

351. See sources cited supra note 350. The MWD participated in an ICS demonstration program in 2006 and 2007. 2015 ACCOUNTING, supra note 149, at 48 .

352. ARIZ. WATER BANKING AUTh., ANNUAl Report 2015, at 1, 11 tbl.4 (2016), http://www.azwaterbank.gov/Plans_and_Reports_Documents/documents/2015Ann ualReportwithletter.pdf [https://perma.cc/7JWC-N8E2] [hereinafter AWBA 2015 REPORT].

353. Id. at 11 tbl.4 (identifying 4,049,657 acre-feet of banked water).
} 
the Interim Guidelines brought into effect in 2008 the ICS program noted above and a Developed Shortage Supply (DSS) program. ${ }^{354}$ Both programs entail storing water in Lake Mead rather than elsewhere.

The ICS program resembles Minute 319's ICMA program outlined earlier, generally allowing parties entitled to use Lower Colorado River water (“contractors") 355 to bank portions of their entitlements in Lake Mead stemming from conservation and augmentation activities. Examples include land fallowing, canal lining, desalination programs, tributary water right purchases, capital contributions to water conservation programs, and importation of non-Colorado River System water. 356 Subject to annual and cumulative limits, contractors create and store ICS in Lake Mead through these activities, relying on the conserved or augmented water in lieu of mainstream deliveries. ${ }^{357}$ At a later date, contractors can request delivery of the ICS, provided the Secretary of the Interior is authorized to release it under conditions specified by the guidelines. ${ }^{358}$ These conditions include that " $\left.\mathrm{t}\right]$ he Secretary has determined an ICS Surplus Condition," evidencing ICS cannot be retrieved during shortages. ${ }^{359}$

Although smaller in scope, the DSS program mirrors the ICS program, with contractors authorized to create DSS by purchasing tributary water rights or importing non-Colorado River System water. ${ }^{360}$ Relying on this tributary or imported water-and banking the mainstream water afforded by their entitlements in Lake Mead-contractors can later request the Secretary of the Interior to release their unused mainstream water (DSS) during a shortage. ${ }^{361}$ More specifically, DSS can be created only in a shortage, DSS must be used in its year of creation, and DSS deliveries cannot cause deliveries to the

354. See Grant, supra note 212, at 975-79 (describing ICS and DSS programs).

355. See INTERIM GUIDELINES ROD, supra note 158, at 30 (defining "contractor").

356. These activities fall into four ICS categories: Extraordinary Conservation ICS, Tributary Conservation ICS, System Efficiency ICS, and Imported ICS. Id. at $38-39$.

357. See id. at 40-42 (prescribing ICS creation rules).

358. See id. at 42-43 (prescribing ICS delivery rules).

359. Id. at 42 ; see also id. at 36 (outlining "Interim Surplus Condition" characteristics).

360. Id. at 44 .

361. Id. at 45 . 
Lower Division states to reach or exceed 7.5 maf. ${ }^{362}$

As with the Lower Basin water banking program, the ICS and DSS programs do not alter the Lower Division states' apportionments under the Arizona $v$. California decree. To ensure conformity with the apportionments, contractors have formed forbearance agreements whereby they have agreed to refrain from using ICS and DSS to which they (and their respective states) otherwise would be entitled.363 These agreements render the water unused and therefore eligible for reallocation by the Secretary of the Interior pursuant to Article II(B)(6).

While nothing has taken place yet under the DSS program, the ICS program has seen a fair amount of activity over the past decade, including both creation of ICS in, and deliveries of ICS from, Lake Mead. In total, four entities have participated: the CAWCD, Imperial Irrigation District (IID), MWD, and SNWA. ${ }^{364}$ The SNWA has been most active. It banked ICS annually from 2008 to $2015,{ }^{365}$ maintaining a 511,023 acre-feet account balance as of 2015. ${ }^{366}$ The MWD likewise has utilized the ICS program, as well as a predecessor ICS demonstration program in 2006 and 2007, to a reasonable extent. The MWD banked ICS consistently across this period, ${ }^{367}$ yet held an account balance of only 80,405 acre-feet as of $2015,{ }^{368}$ due to ICS deliveries in 2008, 2013, 2014, and 2015 totaling 532,581 acre-feet. ${ }^{369}$ Neither the CAWCD nor the IID has been engaged at significant levels. They maintained account balances of 103,050 and 17,386 acre-feet, respectively, as of 2015,370 with

362. Id. at $45-46$.

363. See generally U.S. BurEau of REclamation, Lower COLORAdo River BASIN InTENTIONALly CREATED SuRPlus Forbearance AGREEMENT (2007), http://www.usbr.gov/lc/region/programs/strategies/agreements/Forbearance.PDF [https://perma.cc/ECW6-FWEH].

364. 2015 ACCOUNTING, supra note 149, at 49 tbl.23; 2014 ACCOUNTING, supra note 150 , at 49 tbl.23; 2013 ACCOUNTING, supra note 150, at 45; 2012 ACCOUNTING, supra note 150, at 44; 2011 ACCOUNTING, supra note 150, at 44; 2010 ACCOUNTING, supra note 322, at 44; 2009 ACCOUNTING, supra note 322 , at 45; 2008 ACCOUNTING, supra note 322 , at 45.

365. See sources cited supra note 364 .

366. 2015 ACCOUNTING, supra note 149, at 49 tbl.23.

367. See sources cited supra note 364; see also 2007 ACCOUNTING, supra note 322, at 49; 2006 ACCOUNTING, supra note 322 , at 48.

368. 2015 ACCOUNTING, supra note 149, at 49 tbl.23.

369. See sources cited supra note 364 .

370. 2015 ACCOUNTING, supra note 149, at 49 tbl.23. 
literally or virtually no ICS deliveries having occurred. ${ }^{371}$ Overall, between 2006 and 2015, these four parties banked $1,461,490$ acre-feet of ICS and requested 623,410 acre-feet of ICS deliveries, ${ }^{372}$ translating to a collective net account balance of 711,864 acre-feet in Lake Mead at the period's end. ${ }^{373}$

Moving forward from the Lower Basin water banking and ICS and DSS programs, the final strand of Lower Colorado River shortage avoidance developments consists of two pilot programs that arose in 2014 as part of Lower Basin drought contingency planning.

The first program also involves the Upper Division states and already has been broached: the "Pilot System Conservation Program." 374 Begun in July 2014, this program aims to avoid shortage declarations and critical elevations at Lake Mead by utilizing pooled funding to compensate agricultural, industrial, and municipal water users for voluntary reductions-e.g., agricultural land fallowing or water efficiency improvements. ${ }^{375}$ A total of $\$ 13.75$ million has been made available for projects in the Lower Division states, ${ }^{376}$ and the Bureau of Reclamation's Lower Colorado Region is the administrative entity. ${ }^{377}$ Six projects have been approved by the Bureau to date, and they are collectively expected to conserve roughly 63,000 acre-feet of water in Lake Mead at an average of $\$ 136$ per acre-foot being paid to participants. 378 Stemming from a solicitation issued in March 2016,379 the

371. See sources cited supra note 364 .

372. Id.

373. 2015 Accounting, supra note 149, at 49 tbl.23. These creation and delivery totals reveal how ICS deductions also account for evaporation losses, inadvertent overrun paybacks, and system assessments.

374. See generally CRSCP Agreement, supra note 288.

375. Id. at $6,9,14$.

376. $\$ 8.25$ million in initial funding was provided in July 2014, and $\$ 3.5$ million in additional federal funding was made available in 2016. Pilot Program, supra note 288. The MWD and CAWCD also contributed $\$ 2$ million in additional funding in 2016. Telephone Interview with John Shields, Agric. Eng'r, U.S. Bureau of Reclamation, Lower Colo. Reg'l Office, former Interstate Streams Eng'r, Wyo. State Eng'r's Office (1984-2014) (Aug. 17, 2016) [hereinafter Shields Interview II].

377. Pilot Program, supra note 288.

378. Id.

379. See generally Letter from Terrance J. Fulp, Reg'l Dir., Lower Colo. Region, U.S. Bureau of Reclamation, to Interested Parties (March 25, 2016), http://www.usbr.gov/lc/region/programs/PilotSysConsProg/SecondSolicitationLette r-25March2016.pdf [https://perma.cc/8ET7-CYTY]. 
Bureau is currently signing implementation agreements for a new phase of projects. ${ }^{380}$ Although an evaluation of the program is called for upon its conclusion-to determine whether to extend it or to adopt a long-term program-the precise timing of the program's close and evaluation remain to be seen. 381

Of just slightly more recent vintage in the Lower Basin is a second program of "Pilot Drought Response Actions" that arose in December 2014. ${ }^{382}$ Driven again by concerns about shortages and critical elevations, this program focuses on creating "protection volumes" in Lake Mead. ${ }^{383}$ Its overarching goal is the creation of 1.5 to 3.0 maf of protection volume between 2014 and 2019.384 Program participants have committed to making "best efforts" to create a total of 740,000 acre-feet of protection volume in the following shares by 2018: CAWCD, 345,000 acre-feet; MWD, 300,000 acre-feet; Bureau of Reclamation, 50,000 acre-feet; and SNWA, 45,000 acre-feet. ${ }^{385}$ The SNWA's measures for attaining its goal notably include "reductions in off-stream storage of Colorado River water."386 Other parties intend to generate protection volumes by creating or deferring delivery of ICS. ${ }^{387}$ Water stored in Lake Mead under the Pilot System Conservation Program likewise can be leveraged for this purpose to an extent. ${ }^{388}$ Ultimately,

380. Id.; Shields Interview II, supra note 376.

381. See CRSCP Agreement, supra note 288, at 1, 9, 13 (identifying program's expiration as either July 30, 2016, or December 31 of the year in which the latest implementation agreement expires, and calling for program evaluation and potential subsequent actions after this point).

382. See generally Memorandum OF Understanding AMOng THE U.S., Through the DeP't of the Interior, Bureau of ReClamation, the Cent. Ariz. Water Conservation Dist., the Metro. Water Dist. of S. Cal., the S. Nev. Water Auth., the Ariz. DeP'T of Water Res., the Colo. River Bd. of CAl., AND the Colo. River Comm'N OF Nev. For Pilot Drought Response ACTIONS (Dec. 10, 2014), http://www.hcn.org/external_files/editorial/PilotDrought [https://perma.cc/L64S-QT9M] [hereinafter PDRA Memo].

383. Id. at $5-7$.

384. Id. at 5 .

385. Id. at $6-7$.

386. Id. at $5-6$.

387. Id. at 6 .

388. See id. at 7 (providing for future agreement whereby protection volumes could be created by water conserved through expansion of program); Western Water Supply and Planning Enhancement Act, S. 2902, 114th Cong. § 104 (2016); Pending Legislation: Hearing on S. 2524, S. 2533, S. 2616, S. 2902 \& S. 2907 Before the Subcomm. on Water \& Power of the S. Comm. on Energy \& Nat. Res., 114th Cong. 10 (2016) (statement of Thomas Buschatzke, Dir., Ariz. Dept. of 
the memorandum underlying the program will expire on December 31, 2019.389

One final aspect of the pilot programs deserves mention before concluding this account of institutional evolution along the Lower Colorado River. In July 2016, the Department of the Interior committed to not releasing water stored in Lake Mead by one Lower Division state through these programs to another Lower Division state absent a three-state consensus. 390 This commitment spanned until the end of 2016. ${ }^{391}$ It emerged in lieu of legislation introduced two months earlier by Arizona Senator Jeff Flake aimed at the same goal-albeit on a longterm basis-underpinned by calls from Arizona for "absolute certainty" that system water conserved through the programs would remain in Lake Mead. ${ }^{392}$ Arizona officials described the commitment as "precedential" and expressed hopes that the new administration will "follow suit." 393

By way of summary, the Lower Division states have grown increasingly dependent on flows supplied to the Lower Colorado River as Lake Powell releases over the half-century since The Colorado River-a pattern projected by the Basin Study to heighten to unprecedented levels. Whether these projections play out, and whether existing users of Lower Colorado River enjoy firm or marginal security, has everything to do with the Compact's Article III(c) and (d) flow obligations. While the Arizona $v$. California decree apportions Lower Colorado River water, the Compact flow obligations and corresponding Lake Powell releases provide the primary supply based upon which the Secretary makes annual declarations regarding existent conditions. Stemming from this interface, a structural dynamic arguably more disconcerting than the

Water Res.) (stating "both Intentionally Created Surplus and system conservation water are accounted" for by 740,000 acre-feet protection volume goal) [hereinafter Buschatzke Testimony].

389. PDRA Memo, supra note 382 , at 10.

390. Letter from Michael L. Connor, Dep. Sec'y of the Interior, to Hon. Jeff Flake, U.S. Senator for Ariz. 2 (July 19, 2016), http://www.flake.senate.gov/ public/_cache/files/0905de45-eaf4-4035-8a0f-4afa21b3ec11/connor-flake-coriver.pdf [https://perma.cc/Z2EJ-AQXK].

391. Id.

392. Buschatzke Testimony, supra note 388, at 10-11.

393. Interior Department, Sen. Jeff Flake, Agree to Assuring Arizona Water Remains Arizona's Water, ARIZ. DEP'T OF WATER RESOURCES, http://www.azwater.gov/azdwr/ADWR_News/JeffFlakeArizonaWater.htm (last visited Aug. 15, 2016) [https://perma.cc/ZHP8-LN6H]. 
Upper Division states' "leftovers" is the disconnect between (1) the 8.23 maf historical minimum objective Lake Powell release in the Long-Range Operating Criteria, and lower Lake Powell releases permitted by the Interim Guidelines (e.g., 7.0 maf), versus (2) the 7.5 maf apportioned for normal conditions in the Arizona $v$. California decree. These ends do not meet. And although a wave of shortage administration and avoidance innovations have emerged over the past two decades, it is respectfully unclear whether these efforts and their successors will suffice to close the gap. For although the structural deficit traces at least as far back as the roughly contemporaneous debuts of the Arizona $v$. California decree and Meyers's scholarship, it has become in modern times an imminent matter portending routine Lower Colorado River shortages.

\section{Synthesis, Prognosis \& PRESCRIPTION: AdAPtive FRAMING}

In the fifty-year period since The Colorado River's publication, the Law of the River's international and interstate allocation framework has entered uncharted waters, particularly over the past two decades with the historic drought. Sweeping broadly across this half-century, the framework's constituent apportionments illuminated by Meyers have transitioned from a "Big Buildup" constituted by the plumbing, peopling, and point tipping patterns surveyed in Part II to an "Era of Limits" exemplified by the unprecedented water supply and demand imbalance facing the basin. ${ }^{394} \mathrm{On}$ the supply side, one might say a "reset" has occurred with the historic drought and climate change projections, ${ }^{395}$ and a similar perspective applies to the landmark of demands exceeding supplies on average across the past decade. ${ }^{396}$

"Adaptive framing" captures, as an overarching concept, the iterative and interim nature of the diverse measures examined in Part III that have emerged thus far to adapt the allocation framework to the Era of Limits. As referenced earlier, this concept accounts for three broad types of adaptive patterns that can be discerned when analyzing from a

394. See supra notes 29 and 30 and accompanying text.

395. Telephone interview with Dr. Terry Fulp, Regional Dir., U.S. Bureau of Reclamation, Lower Colo. Region (Jan. 9, 2016) [hereinafter Fulp Interview].

396. STUDY REPORT, supra note 6, at SR-7 fig.2. 
comparative perspective the numerous (and, in some cases, parallel) innovations to the framework's constituent apportionments. These patterns are part and parcel of adaptive framing. Retrospectively, the patterns synthesize the slew of evolutionary material and characterize the allocation framework's contemporary form. Prospectively, the patterns provide insights into how the allocation framework foreseeably will, and arguably should, evolve in coming decades. The discussion below fleshes out the adaptive patterns in full. It begins by addressing the utilization of reservoir operating regimes for water-use rationing and risk allocation, then turns to the "surrogate" role played by these regimes as management tools for interpretive conflicts, and concludes by focusing on the varied measures developed in recent years for avoiding or mitigating constraints on consumptive use imposed by the apportionments. Each section assumes a standardized form, initially synthesizing evolutionary material in Part III evidencing the particular pattern, and then considering from positive and normative angles that pattern's persistence.

\section{A. Of Boundaries: Rationing \& Risk Allocation}

\section{Operational Apportionment Implementation}

A threshold adaptive pattern evident in the allocation framework's evolution since Meyers's scholarship concerns the widening scope of institutional preparations for implementing the framework's apportionments during water shortages and low-reservoir conditions. Adaptation of most, yet not all, of the apportionments has involved multi-party, negotiated formulation of reservoir operating regimes aimed at outlining precisely how the apportionments will be implemented in response to diminished flows and reservoir levels. From a planning and risk management perspective, these regimes provide water users with clarity and certainty, and simultaneously conserve reservoir storage through elevation tier-based rationing, albeit with a shared understanding of the regimes' impermanent nature.

All of the reservoir operating regimes serving this apportionment-implementation function have arisen during the historic drought and are slated to continue in their current or successive forms for an interim period upwards of roughly ten 
years. Specifically, the Interim Guidelines established the coordinated operating regime for Lake Powell and Lake Mead, as well as Lake Mead's individual operating regime, in 2007. At bottom, the former implements the Compact's Article III(c) and (d) flow obligations, while the latter implements Article II(B)(3) of the Arizona v. California decree. Five years later, in 2012, Minute 319 incorporated the latter regime's elevation tiers when crafting shortage-sharing rules for the U.S.-Mexico Treaty. Looking ahead, Minute 319's regime will expire on December 31, 2017, with a potential comprehensive Minute extending it in some form through December 31, 2026.397 Additionally, the Interim Guidelines regimes will be subject to formal review beginning no later than December 31, 2020, and are set to expire on December 31, 2025. ${ }^{398}$

\section{Toward Further Clarity, Comity \& Equity}

The genesis of these reservoir operating regimes was not a flash in the pan, but rather a milestone that foreseeably will and should guide the allocation framework's ongoing adaptation. Promotion of clarity, certainty, and conservation are laudable goals. Consider again the Basin Study's arguably conservative projections regarding climate change-based reductions in Lee Ferry flows (e.g., mean projection of an 8.7\% decrease in historical levels by 2060), ${ }^{399}$ coupled with its counterparts suggesting increased consumptive use in both the Upper Basin (e.g., 5.5 maf by 2060 excluding reservoir evaporation) 400 and the Lower Basin (e.g., 9.0 maf by 2060 excluding reservoir evaporation). ${ }^{401}$ The accuracy of these projections remains to be seen, but their convergence suggests, if anything, an even higher premium should be placed in the future on continuing to use clearly delineated, conservationoriented operating regimes to implement the apportionments. Three specific points are worth considering along these lines.

An initial point concerns the absence of curtailment guidelines for Article IV of the Upper Basin Compact. While such guidelines cannot be equated literally with the Interim

397. MinUTE 319 , supra note 136 , at 3.

398. INTERIM GUIDELINES ROD, supra note 158, at 56-57.

399. TECHNICAL REPORT B, supra note 8, at B-66.

400. TECHNICAL REPORT C, supra note 35, at C-25 fig.C-9.

401. Id. 
Guidelines' and Minute 319's reservoir operating regimes, these measures do share a common function of mapping out how the respective apportionments will be implemented in response to precarious flow levels and reservoir storage. From this angle, the lack of clarity and certainty regarding Article IV's administration distinguishes the Upper Basin Compact's apportionment from its counterparts. This observation is in no way intended to disregard Upper Division state policymakers' confidence in the Interim Guidelines and Basin States' Agreement preventing a Compact call and curtailments prior to 2026. Nonetheless, it seems sensible to clarify Article IV's nuances proactively in just such a "safe harbor," rather than to kick the proverbial can down the road for others to tackle these challenges reactively with marginal breathing room. Further, the work begun by the Upper Colorado River Commission's Engineering Advisory Committee several years ago to develop Article IV guidelines suggests a reinvigoration of this effort would be less taxing than if pursued from scratch. ${ }^{402}$

A related point involves California's current insulation from shortage sharing under the Interim Guidelines' operating regime for Lake Mead. As suggested by the Lower Basin drought contingency planning effort, this insulation needs to be reassessed. It arguably runs contrary to foundational Law of the River principles like equity and comity (i.e., providing for equitable apportionment of Colorado River System water, and promoting comity in sovereign relations over this water). ${ }^{403} \mathrm{As}$ outlined earlier, Arizona's and Nevada's apportionments in the Arizona $v$. California decree stand to diminish from 2.8 to 2.32 maf and 300,000 to 280,000 acre-feet, respectively, under the Interim Guidelines' regime. ${ }^{404}$ These reductions equate to approximately $17.1 \%$ and $6.7 \%$ of the apportionments. Minute 319 's parallel regime similarly contemplates treaty deliveries to a nation-state falling from 1.5 to 1.25 maf annually-a roughly $16.7 \%$ diminution. ${ }^{405}$ California does not shoulder the shortage burden at all. Reductions ranging from 294,800 to 752,400 acre-feet would be in order if its 4.4 maf apportionment were subject to the $6.7 \%$ and $17.1 \%$ reductions respectively

402. See SEO PLAN, supra note 258, at 5 (noting guideline drafting efforts).

403. See Compact, supra note 18, § 37-61-101, art. I (articulating equity and comity principles).

404. INTERIM GUIDELINES ROD, supra note 158, at 37.

405. MINUTE 319 , supra note 136 , at 6 . 
borne by Nevada and Arizona. At the end of the day, notwithstanding its post-Arizona $v$. California statutory priority vis-à-vis Central Arizona Project water users, ${ }^{406}$ this approach to shortage "sharing" warrants rethinking. Two commonsensical but critical aspects of it deserve attention relevant to the equity and comity principles: (1) scalingestablishment (and perhaps standardization) of the precise elevation tiers at which the respective Lower Division states and Mexico will be subject to shortage reductions, and (2) rationing-prescription of the relative amounts of shortage reductions at the particular tiers. These considerations warrant sustained, fair-minded attention both in the ongoing drought contingency planning process and the Interim Guidelines' formal review.

Last but not least is a broad, heavy point regarding implementation of the Compact's apportionment-specifically, its Article III(c) and (d) flow obligations-through the Interim Guidelines' coordinated operating regime for Lake Powell and Lake Mead. ${ }^{407}$ Simply put, no guidelines' component requires higher prioritization and scrutiny during the upcoming formal review. Implemented by this regime, the Article III(c) and (d) flow obligations in no uncertain terms control the respective amounts of water available for apportionment under the Upper Basin Compact and Arizona v. California decree. Again, there is "reciprocal constraint" and concomitantly an existential assignment of risk. This dynamic is inherent to the allocation framework's existing design, and it is critical to recognize when evaluating how rationing and risk allocation should be handled under a successive regime for coordinating the reservoirs' operations and thus implementing the Law of the River's "constitution." 408 Capitalizing on operational experience from the Interim Guidelines, the regime's elevation tiers and Lake Powell release schedules must comport with the Compact's equity and comity principles. ${ }^{409}$ It should foster basinwide cooperation and sharing, including mutual sacrifice.

406. Colorado River Basin Project Act § 301(b), 43 U.S.C. § 1521(b) (2012).

407. INTERIM GUIDELINES ROD, supra note 158, at 56.

408. See Adler, supra note 154, at 21 (analogizing Compact to constitution).

409. Compact, supra note $18, \S 37-61-101$, art. I (articulating equity and comity principles). 


\section{B. Of Surrogacy: Interpretive Conflict Management}

\section{Surrogacy}

There is an intertwined adaptive pattern apparent in the allocation framework's evolution since The Colorado River that has involved the reservoir operating regimes just discussed in a distinct yet related way. Enmeshed with their apportionmentimplementation functions, these regimes also have served as interpretive conflict management mechanisms-more precisely, as mechanisms for managing actual or potential conflicts surrounding contrary interpretations of the apportionments' framing provisions. The regimes may be conceived of as "surrogates" for traditional approaches to such conflicts like litigation. ${ }^{410}$

Two key instances of this pattern are apparent. First, the Interim Guidelines emerged in 2007 as an instrument for handling entrenched disagreements over the Upper Division states' obligation to contribute treaty flows under Article III(c) of the Compact. ${ }^{411} \mathrm{Up}$ to December 31, 2025, the guidelines' coordinated operating regime for Lake Powell and Lake Mead-coupled with the Basin States' Agreement and its mandatory consultation requirement-will provide the mechanism for addressing these multifaceted disputes. ${ }^{412}$ Second, originating five years after the Interim Guidelines, Minute 319's shortage-sharing rules for treaty deliveries fill a vacuum emanating from the arguably inadministrable text of Article 10(b) of the U.S.-Mexico Treaty. ${ }^{413}$ Article 10(b) remains unabridged. But Minute 319 accomplishes up to December 31, 2017, what may have been practically impossible if it would have been necessary to give expression to "extraordinary drought" and adjacent perplexing terms. ${ }^{414}$ This author anticipates a comprehensive Minute indeed will fulfill this role

410. Fulp Interview, supra note 395.

411. See supra section III.B.3.

412. INTERIM GUIDELINES ROD, supra note 158, at 57; Basin States' Agreement, supra note 158, at 13. As noted earlier, the Basin States' Agreement's mandatory consultation provision states it will survive for five years beyond the agreement's expiration or termination. Basin States' Agreement, supra, note 158, at 10 .

413. See supra section III.A.3.

414. MinUTE 319 , supra note 136 , at 3. 
until December 31, 2026. ${ }^{415}$

\section{Second-Best Solutions \& Surrogacy Reassessed}

As with rationing and risk allocation, the Basin Study's water supply and demand projections suggest the need for wellconceived measures for managing actual or potential interpretive conflicts rooted in the apportionments may very well heighten going forward. Consider as a case in point the Article III(c) disputes preceding the Interim Guidelines' formation. These conflicts ensued with the historic drought and "brought the basin closer to multi-state and inter-basin litigation than perhaps any time since adoption of the Compact." 416 There are many related ambiguities in the Compact - as examined in Part III-and other parts of the Law of the River whose clarification similarly may require delicate handling in coming years.

Yet this general prognosis raises challenging questions as applied to the existing reservoir operating regimes and their surrogacy. Does the Interim Guidelines' coordinated operating regime for Lake Powell and Lake Mead, coupled with the Basin States' Agreement, provide the optimal way to address Article III(c)? If not, which alternatives may be preferable and why? Similar queries might also be posed for Article 10(b) of the U.S.-Mexico Treaty, but my focus will stay at the domestic level. Given Article III(c)'s significance within the Compact's apportionment, it is critical for policymakers to engage these questions in conjunction with the guidelines' formal review. ${ }^{417}$ A few associated comments will be offered.

As a starting point, the apparent virtue or vice of the existing approach to Article III(c) is that it is, by definition, temporary and avoids any formal interpretation of the provision or its counterparts. It constitutes an "interim and avoidant" conflict management method. These attributes make sense. The "immediate challenge" to which the Interim Guidelines responded was "how to resolve the conflicting views of the Upper and Lower Division states" regarding Article III(c) "for an interim period in order to allow enough time to reach a

\footnotetext{
415. Id.

416. See INTERIM GUIDELINES ROD, supra note 158, at 11 .

417. See Grant, supra note 212, at 983-84 (discussing Article III(c)'s significance to water availability).
} 
long-term solution." 418 Nearly a decade later, however, what is the long-term solution? More to the point, might it be desirable for this solution to settle Article III(c)'s interpretation and implementation in a more lasting manner? To what extent, if any, is it problematic for the provision's meaning essentially to be left hanging out there? An approach to Article III(c) that is more solid temporally and substantively might be conducive to progressive water planning and management in the Basin States. ${ }^{419}$ Such an approach also might provide heightened assurance that the Secretary of the Interior's reservoir operations indeed comply with Article III(c). ${ }^{420}$

But this branch of the allocation framework's evolution is rife with second-best solutions. While the Interim Guidelines' interim and avoidant qualities may be suboptimal features of an Article III(c) conflict management method, alternatives pose seemingly steeper challenges. Consider for starters reverting to the Long-Range Operating Criteria for Lake Powell's and Lake Mead's operation after the guidelines expire. These criteria reference an 8.23 maf minimum objective release from Lake Powell annually, and this floor is markedly higher than the 7.0 and 7.48 maf releases allowed under the guidelines. ${ }^{421}$ The flexibility, if any, of the 8.23 maf minimum objective release is unclear to this author, but neither its higher floor nor its contested inclusion of an Upper Division states' treaty flow contribution appear to be attributes favored by those states. That said, the Long-Range Operating Criteria and Interim Guidelines do share common ground vis-à-vis Article III(c) in that neither entails formal interpretation of the provision or its neighbors. ${ }^{422}$ Such interpretations might issue from the Supreme Court. But as Arizona v. California poignantly exemplifies, "[t]he terror of original jurisdiction litigation is its

418. Schiffer et al., supra note 196, at 218 (internal punctuation omitted).

419. See Getches \& Meyers, supra note 248, at 58 ("If the precise obligations of the Upper Basin states were known, planning for growth and for future water projects could be done more intelligently.”).

420. See Colorado River Basin Project Act § 601(c), 43 U.S.C. § 1551(c) (2012) (mandating compliance); Colorado River Storage Project Act $\S 14,43$ U.S.C. § 620m (2012) (same).

421. Compare LROC, supra note 205, at art. II(2), with INTERIM GUIDELINES ROD, supra note 158, at 50, 52-53.

422. See LROC, supra note 205, at art. IV(b) (disclaiming interpretive effect on "surplus" in Article III(c)); INTERIM GUIDELINES ROD, supra note 158, at 57 (providing reservoir operations under guidelines "shall not represent interpretations of existing law"). 
unpredictability." 423 Further considerations include exorbitant costs, attenuated timelines, and interstate acrimony, rather than comity, all of which would heighten if "interpretive creep" were to occur such that a narrow Article III(c) question ballooned into broad Compact construction. ${ }^{424}$ These concerns assuredly underpin the Basin States' Agreement's mandatory consultation provision. ${ }^{425}$ Article VI of the Compact also deserves mention in this vein. It outlines a procedure for Basin States to resolve "any claim or controversy" regarding the "meaning or performance of any of the terms of this compact" by appointing "Commissioners with power to consider and adjust such claim or controversy." 426 Although possibly attractive at first blush, any resolution forged by the Commissioners is "subject to ratification by the Legislatures of the States so affected." 427 Some circularity and, most critically, a veto power are thus drawbacks.

"Most problems concerning the allocation and management of river resources ideally would be resolved by mutual agreement of the states...."428 Applicable to Article III(c)'s future handling and otherwise, Meyers and David Getches expressed this view two years before Meyers's passing in 1988. ${ }^{429}$ It circles back to the Interim Guidelines and Basin States' Agreement. Their consensual nature foreseeably will and should guide prospective approaches to Article III(c). The downsides of alternatives are daunting-particularly, Supreme Court litigation. A salient question, however, is what else can consensus yield? Could consensus-based processes amend Article III(c) in isolation to make its meaning explicit? Such an effort might involve collaboration and control that would distinguish it from attempts to tailor litigation narrowly to Article III(c) and avoid interpretive creep. Given its connection with other Compact provisions, however, this dynamic seems inevitable even outside litigation. ${ }^{430}$ From this perspective, the existing surrogate approach very well may be the best

423. Carlson \& Boles, supra note 199, at $\S 21.04[3]$.

424. See Kuhn, supra note 171, at 32 (describing how Supreme Court could not interpret Article III(c) without interpreting other provisions).

425. Basin States' Agreement, supra note 158, at 10.

426. Compact, supra note 18, § 37-61-101, art. VI.

427. Id.

428. Getches \& Meyers, supra note 248, at 70.

429. HALL, supra note 12, at 194-95.

430. Fulp Interview, supra note 395. 
consensus-based option possible, notwithstanding its interim and avoidant qualities. Assuming so for now, key subjects requiring attention during formal review of the Interim Guidelines' coordinated operating regime include (1) the regime's specific treatment of Article III(c) flow volumes in its Lake Powell release schedules, and (2) the regime's duration and provision for off-ramps (reconsultation) if severe climate change-based reductions in Lee Ferry flows occur.

\section{Of Economy: Constraint Avoidance \& Mitigation}

\section{Programmatic Iteration}

Overlapping inextricably with the material above on interpretive conflict management and rationing and risk allocation is a third adaptive pattern readily discernible in the allocation framework's evolution since The Colorado River. It involves the emergence of conservation- and flexibility-oriented measures aimed at avoiding, and mitigating the impacts of, constraints on consumptive use imposed by the apportionments. Alongside augmentation efforts and rationing rules prescribed by the reservoir operating regimes, these measures bear directly on the water supply and demand imbalance's current and future scope.

A host of programs fall within this line. They include the Lower Basin water banking program formed in 1999, the Interim Guidelines' ICS and DSS programs adopted in 2007, Minute 319's deferred deliveries programs (water deferred and ICMA) formulated in 2012, and the Pilot System Conservation Program and Pilot Drought Response Actions program commenced in 2014. This author anticipates most, if not all, of these programs will persist in successive forms. To synthesize the state of play, however, Minute 319's water deferred and ICMA programs will expire on December 31, 2017,431 and the Pilot Drought Response Actions program will operate up to December 31, 2019. ${ }^{432}$ The timeline for the Interim Guidelines' ICS and DSS programs is more nuanced. Portions of the former program involving Extraordinary Conservation ICS and

431. Minute 319, supra note 136, at 19. Deferred deliveries may occur afterward. Id.

432. PDRA Memo, supra note 382, at 10. 
System Efficiency ICS will lapse on the general expiration date, December 31, 2025, while portions governing Tributary ICS and Imported ICS, as well as the DSS program, will run until December 13, 2057.433 As for the Pilot System Conservation Program, its sunset is tethered more openendedly to December 31 of the year in which the latest implementation agreement expires. ${ }^{434}$ Overall, the programs thus largely (though not uniformly) will continue in their existing forms for a relatively limited period of ten years.

\section{Diffusion \& Performance-Based Assessment}

Paralleling the other adaptive patterns, further innovations aimed at conserving, and affording flexibility in the use of, Colorado River System water appear as inevitable as they are sensible. Yet again the water supply and demand imbalance, coupled with the Basin Study's projections of climate change-based Lee Ferry flow reductions and basinwide consumptive use increases, support this general prognosis and prescription. My specific commentary regarding the continuation of this pattern into the future concerns two topics: (1) diffusion of a Lower Colorado River program analogue within the Upper Basin, and (2) performance-based assessments of the Lower Colorado River programs and derivative insights.

Existing programs in this realm fall almost exclusively along the Lower Colorado River. This disparity tees up the need for innovation above Lee Ferry. Only the Pilot System Conservation Program applies within the Upper Basin-a $\$ 3.75$ million portion of it to be precise ${ }^{435}$-while the preponderance of this program and entirety of its counterparts adhere within the Lower Basin. At the same time, the water supply and demand imbalance and Basin Study's projections suggest a hefty premium should be placed on measures to conserve, and to afford flexibility to users of, the "leftovers." The Pilot System Conservation Program reflects this priority, as do emerging intrastate water banking and temporary

433. INTERIM GUIDELINES ROD, supra note 158, at 57-58. The general expiration date does not apply to deliveries of Extraordinary Conservation ICS and System Efficiency ICS. Id. at 58.

434. CRSCP Agreement, supra note 288, at 9 .

435. See sources cited supra note 291. 
transfer arrangements addressing the distribution of pre- and post-1922 water rights in Upper Division states. ${ }^{436}$ Yet there is no analogue under the Upper Basin Compact to (1) the Lower Basin water banking program or Interim Guidelines' ICS and DSS programs associated with the Arizona $v$. California decree, or (2) the deferred deliveries programs under the U.S.-Mexico Treaty. An interstate analogue of this type should be envisioned. And as with the preparation of Article IV curtailment guidelines for the Upper Basin Compact, it seems prudent for this process to occur now rather than in a potentially higher-pressure future setting. The Basin Study again evidenced support for this idea, ${ }^{437}$ and reference points assuredly could be found in the Pilot System Conservation Program, Lower Colorado River programs, and ongoing intrastate water banking efforts.

Shifting attention downstream of Lee Ferry, a host of comments could be offered about the Lower Colorado River programs' future, but mine will be framed around one presumably uncontroversial proposition: the prospective existence and shape of these programs should be informed by assessing their actual performance on the ground. Are the programs achieving programmatic and collective conservation goals to the extent, and in the particular manner, considered optimal or necessary? This question needs to be asked and pursued on a recurring basis. It is difficult or impossible to answer at this time for certain programs due to their recency (Pilot System Conservation Program, Pilot Drought Response Actions program) or non-utilization (Interim Guidelines' DSS program, Minute 319's ICMA program). Nonetheless, several insights can be gleaned from programs that have seen action thus far below Lee Ferry, especially those associated with the Arizona $v$. California decree (Lower Basin water banking program, Interim Guidelines' ICS program). Four takeaways are notable.

First, the Lower Basin water banking program seems to undermine the other Lower Colorado River programs' core goal of conserving Lake Mead's storage to prevent shortages and critical elevations. As detailed in Part III, the SNWA has been the sole entity to utilize this program to date, banking 931,266

436. See supra section III.C.2.a.

437. TECHNICAL REPORT F, supra note 268 , at F-59 to -60 . 
acre-feet in offstream locations as of $2015 .{ }^{438}$ This water surely provides valuable security for dealing with shortages under the Interim Guidelines. By definition, however, it is not banked in Lake Mead. As flagged above, the Pilot Drought Response Action program appears to reflect this programmatic tension by allowing creation of protection volumes through "reductions in off-stream storage of Colorado River water." 439 In short, if conserving Lake Mead's storage is paramount, the Lower Basin water banking program needs to be understood as contrary to this goal. Its role within the Lower Colorado River programs as a suite needs to be re-evaluated, including potentially curbing its usage and devising measures to motivate entitlement holders like the SNWA to bank water in Lake Mead through the ICS program instead. The SNWA's activities since the ICS program came online support this transition. Whereas the SNWA stored 552,520 acre-feet through the Lower Basin water banking program from 2001 to 2007, it stored 378,746 acre-feet via the program from 2008 to 2015, simultaneously creating 627,713 acre-feet of ICS across the latter period.440 All told, drawing down Lake Mead's storage to bank Colorado River System water elsewhere is not a self-regarding act, whether in the form of the SNWA's 931,266 acre-feet banked through the Lower Basin program or the AWBA's 3.4 maf banked on an intrastate basis. ${ }^{441}$ This roughly 4.3 maf impacts all parties conjoined by the shortage-sharing rules for Lake Mead, domestically and internationally, as well as by the coordinated operating regime for it and Lake Powell. ${ }^{442}$

Second, participation in the ICS program has been relatively modest to date, evincing a need for strategies to promote higher levels of engagement and conservation. More than 150 parties hold entitlements to Lower Colorado River water, with roughly a dozen entitled to consume or divert over 100,000 acre-feet annually. ${ }^{443}$ Yet only the SNWA and MWD

438. 2015 ACCOUNTING, supra note 149, at 34 tbl.12.

439. PDRA Memo, supra note 382, at 6 .

440. See sources cited supra notes 350 and 364 .

441. AWBA 2015 REPORT, supra note 352, at 1, 11 tbl.4.

442. This point may be thought of in terms of relative beneficiaries. The scope of "mitigation beneficiaries" of this 4.3 maf in banked water is plainly narrower than the scope of parties that would benefit if the water (i.e., that portion of it capable of storage as ICS) instead had been stored in Lake Mead.

443. Lists of these parties can be found at Lower Colorado River Water Entitlements Listing, U.S. BUREAU OF RECLAMATION, http://www.usbr.gov/lc/ 
have been significant ICS program participants, while the CAWCD and IID have been marginally engaged. As noted earlier, these parties created 1,461,490 acre-feet of ICS in Lake Mead between 2006 and 2015 in the following shares: MWD, 698,860 acre-feet; SNWA, 627,713 acre-feet; CAWCD, 103,050 acre-feet; and IID, 31,867 acre-feet. ${ }^{444}$

Two broad issues stem from these figures: (1) how to motivate more Lower Colorado River entitlement holders to participate in the ICS program, and (2) how to prompt higher levels of ICS creation by participants. One simple but practical response concerns Bureau of Reclamation marketing. ${ }^{445}$ Perhaps more intensive efforts to disseminate ICS program information to, and to solicit engagement by, entitlement holders might be a boon. Another angle involves re-evaluating ICS creation limits. Liberalization of annual and cumulative caps on the creation of Extraordinary Conservation ICS deserves thought. ${ }^{446}$ So, too, does reassessment of limits on ICS retrieval-specifically, provisions limiting the circumstances in which ICS can be delivered and annual deliveries of Extraordinary Conservation ICS. 447 Admittedly, these delivery limits entail striking a delicate balance between protecting Lake Mead's storage on one hand, and avoiding the disincentivizing perception and possible reality that ICS will become a stranded asset on the other. ${ }^{448}$ ICS alienability is a final topic of note. Although allowing market-based transfers of ICS might spur program participation and ICS creation, the Interim Guidelines do not by their terms address such transfers, instead focusing solely on ICS retrieval by entitlement holders that created it. ${ }^{449}$ In contrast, the Lower Basin water banking program expressly allows non-federal

region/g4000/contracts/entitlements.html (last updated June 4, 2015) [https://perma.cc/75TZ-8954]. Parties with entitlements allowing for consumptive use or diversion of more than 100,000 acre-feet annually include the CAWCD, CVWD, Colorado River Indian Reservation, Fort Mojave Indian Reservation, IID, MWD, Palo Verde Irrigation District, SNWA, Wellton-Mohawk Irrigation and Drainage District, Yuma County Water Users' Association, and Yuma Mesa Irrigation and Drainage District. Id.

444. See sources cited supra note 364 and 367.

445. Fulp Interview, supra note 395.

446. See INTERIM GUIDELINES ROD, supra note 158, at 41 (imposing ICS creation limits).

447. See id. at 42-43 (prescribing ICS delivery limits).

448. Fulp Interview, supra note 395.

449. See INTERIM GUIDELINES ROD, supra note 158, at 27. 
parties to a SIRA to assign their interests to consuming or storing entities. ${ }^{450}$ It is worth considering how the ICS program might be similarly tailored, including the formulation of policies governing (1) eligibility (types of parties eligible to engage in ICS transfers); ${ }^{451}$ (2) review processes (procedural steps for submitting ICS transfer proposals and review criteria); and (3) accounting (verification and accounting methods for ICS transfers).

Third, contrasting with the retrieval-oriented nature of the ICS program and Minute 319's water deferred program, the "system water" concept of the Pilot System Conservation Program warrants further study as a potentially more effective means for conserving Lake Mead's storage. By the pilot program's terms, "system conservation water" accrues "to the benefit of the overall Colorado River System, not for the benefit of any Local Funding Agency, System Conservation Implementation Agreement signatory, or third-party." 452 None of these parties can retrieve system water once it has been created. This non-retrieval aspect of the program is distinct from its predecessors, which, as identified earlier, enabled 728,478 acre-feet to be withdrawn from Lake Mead over the preceding decade-623,410 and 105,068 acre-feet of ICS and water deferred, respectively. ${ }^{453}$ Allowing such retrievals fully makes sense from an incentivization perspective. But it also seems plain that dedicating conserved water to the Colorado River System might more effectively shore up storage. Policymakers should analyze carefully the system water concept's efficacy as the pilot program rolls out, including while assessing its extension or permanence. Two historical and projected figures deserve close attention: (1) yield-to-cost ratio-the ratio of system water conserved, or capable of being conserved, to program expenditures, and (2) marginal efficiency - the relative conservation achieved through system water expenditures as compared to alternative conservation potentially achieved through ICS or other Pilot Drought Response Actions program investments. System water funding

450. 43 C.F.R. $\S 414.3(d)(2016)$.

451. An interesting issue regarding eligibility is whether ICS might be transferred to parties interested in non-consumptive use of it-e.g., for retention in Lake Mead or perhaps downstream instream flows.

452. CRSCP Agreement, supra note 288, at 14.

453. See sources cited supra notes 149, 150, 364, and 367. 
poses challenges, ${ }^{454}$ but solid marks in these areas would favor the concept's growth.

Fourth, and of greatest importance, the collective performance of the Lower Colorado River programs up to this point very much leaves open to question, in this author's view, the capacity of these programs and their counterparts to address the fundamental challenge facing the Lower Division states: the structural deficit. This concern is grave, but it needs to be addressed openly, and one way of doing so is by looking a few things in the face.

Consider initially the bottom line regarding conservation of Lake Mead's storage. The Lower Colorado River programs appear to have bolstered it, or to be in the process of bolstering it, by slightly over 1.0 maf since the ICS program's genesis. The ICS and water deferred programs appear to have made a contribution of roughly 980,000 acre-feet. Specifically, the Bureau of Reclamation's most recent water accounting report in 2015 noted balances of 711,864 acre-feet of ICS and 230,528 acre-feet of water deferred, ${ }^{455}$ and 40,851 acre-feet should be added to the former per a system assessment. ${ }^{456}$ Supplementing this conservation is the 63,000 acre-feet yield anticipated for the Lower Basin component of the Pilot System Conservation Program. ${ }^{457}$ Taken together, this conserved storage totals 1,046,243 acre-feet. 458

Cutting the other way is the Lower Basin water banking program's depletion of Lake Mead. As acknowledged earlier, the SNWA's offstream banking under this program (as well as that of the AWBA on an intrastate basis) undoubtedly provides valuable security given the seeming eventuality of a Lower Colorado River shortage. That said, it bears highlighting that the 931,266 acre-feet drawn from Lake Mead by the SNWA closely approximates the 1,046,243 acre-feet in conserved storage just noted. 459 A net gain of 114,977 acre-feet in Lake

454. Fulp Interview, supra note 395.

455. 2015 ACCOUNTING, supra note 149, at 28 tbl.9, 49 tbl.23.

456. See INTERIM GUIDELINES ROD, supra note 158, at 40 (imposing assessment). This 39,594 acre-feet figure is derived from the sources cited supra notes 364 and 367.

457. Pilot Program, supra note 288.

458. This total does not account for activities being undertaken under the Pilot Drought Response Actions program that go beyond either ICS creation or water storage through the Pilot System Conservation Program.

459. 2015 ACCOUNTING, supra note 149, at 34 tbl.12. 
Mead's storage appears to be the end result of the Lower Colorado River programs' interplay.

Now ultimately reconcile these figures with the structural deficit. To reiterate, a basic rule of thumb is that if annual releases from Lake Powell average 8.23 maf (historical minimum objective release), and annual consumptive use along the Lower Colorado River averages 7.5 maf (Arizona $v$. California decree's apportionment for normal conditions), "Lake Mead will lose about a million acre-feet of storage per year." 460 More precisely, the deficit is understood to range from 1.0 to 1.2 maf annually. ${ }^{461}$ And the Basin Study's projections suggest it is not going away. The forecast of decreased Lee Ferry flows due to climate change and increased consumptive use in Upper Division states suggests average annual Lake Powell releases will approximate the legal minimum in coming years. Assuming that minimum is 8.23 maf and not something less, the obvious point is that the structural deficit exceeds by an order of magnitude the conservation as-yet yielded by the Lower Colorado River programs-again, 114,977 acre-feet of additional Lake Mead storage. Even focusing solely on the $1,046,243$ acre-feet of conserved storage since the ICS program's emergence-and ignoring the 931,266 acre-feet of offstream interstate water banking-the former amount is equivalent to approximately one year of the structural deficit. A Herculean effort is needed from this vantage point. And the geneses of the Lower Basin pilot programs and drought contingency plan are wholly unsurprising in this light. So, too, is ongoing discourse about the perceived need for large-scale augmentation, ${ }^{462}$ the questionable adequacy of the Interim Guidelines to stave off Lake Mead's continued decline, ${ }^{463}$ and, when all is said and done, "the responsibility of all Lower Basin states and water users and the United States to take action to close the structural deficit." 464

460. Kuhn, supra note 171 , at 34 .

461. Id.; CAP 2015 REVIEW, supra note 320 , at 2.

462. BASIN STATES' COMMITMENTS, supra note 86, at 3.

463. See, e.g., Cent. ARIZ. Project, 2014 YeAR IN REview 8 (2014), http://www.cap-az.com/documents/departments/finance/CAP-2014-Year-In-

Review.pdf [https://perma.cc/CKX9-VA4N] (quoting CAP Deputy General Manager of Maintenance and Operations, Tom McCann, as describing Interim Guidelines "will not be sufficient to prevent the continued decline of Lake Mead").

464. Cent. Ariz. Project, The State of the Colorado River 2 (2014) (emphasis added), http://www.cap-az.com/documents/departments/planning/ 
V. CONCLUSION

The structural deficit along the Lower Colorado River is a weighty but fitting topic on which to conclude, for it brings the discussion full circle to the Introduction-to Lady Bird Johnson's dedication of Glen Canyon Dam fifty years ago in the heart of Interior Secretary Stewart Udall's "superlative" "home country," 465 and to former Stanford Law School Dean Charles Meyers's contemporaneous publication of The Colorado River.

So much of what has filled the preceding pages-as well as those of Meyers's "magisterial" piece ${ }^{466}$ _has to do with Rocky Mountain snowmelt impounded by Glen Canyon Dam. It is this snowmelt that largely animates the living river system called the "Colorado," and that has been the highly coveted prize around which the Law of the River's allocation framework has grown since Meyers's scholarship and a half-century prior. Diverse changes are apparent when considering the original and current states of the apportionments performing the multilayered, multi-jurisdictional allocation. And inextricable with these changes are numerous socio-legal factors reflecting evolving conditions and values within and beyond the Colorado River Basin. It is and always will be an instance of institutional evolution embedded within broader social evolution, and reciprocity between water law and the social order that is its "habitat." 467 While it is hoped that the evolutionary survey and adaptive framing commentary in the previous Parts prove of practical value to readers, it is this deeper topic of the Law of the River's formative role in shaping foundational aspects of the social order in and around the basin that will be sounded on a final note. "Conflicts over the river... encompass values that run to the core of our social organization." 468 Meyers and David Getches expressed this point elegantly thirty years ago: "New industry may supplant a pastoral society; the quality of life in a vast land area may rise or fall; major demographic shifts may occur; nature's plan for an entire region may be forever obscured; ancient Indian

465. GLEN CANYON TRANSCRIPT, supra note 1 , at 3 .

466. HALL, supra note 12, at 168.

467. WILKINSON, supra note 22 , at 81 .

468. Getches \& Meyers, supra note 248, at 52-53. 
cultures may live or die." 469 The truth of these words is irrefutable. And their gravity cannot be taken lightly. For they reflect what has always been at stake: "a national symbol of the highest order," 470 flowing through a "very precious and very special" 471 place, whose "heritage . . is so much richer" 472 than we may ever know.

469. Id. at 53 .

470. Id. at 51 .

471. GLEN CANYON TRANSCRIPT, supra note 1 , at 10 .

472. Id. 